\title{
Global Carbon Budget 2016
}

Corinne Le Quéré1 ${ }^{1}$ Robbie M. Andrew ${ }^{2}$, Josep G. Canadell ${ }^{3}$, Stephen Sitch ${ }^{4}$, Jan Ivar Korsbakken², Glen P. Peters ${ }^{2}$, Andrew C. Manning ${ }^{5}$, Thomas A. Boden ${ }^{6}$, Pieter P. Tans ${ }^{7}$, Richard A. Houghton ${ }^{8}$, Ralph F. Keeling ${ }^{9}$, Simone Alin ${ }^{10}$, Oliver D. Andrews ${ }^{1}$, Peter Anthoni ${ }^{11}$, Leticia Barbero ${ }^{12,13}$, Laurent Bopp ${ }^{14}$, Frédéric Chevallier ${ }^{14}$, Louise P. Chini ${ }^{15}$, Philippe Ciais ${ }^{14}$, Kim Currie ${ }^{16}$, Christine Delire $^{17}$, Scott C. Doney ${ }^{18}$, Pierre Friedlingstein ${ }^{19}$, Thanos Gkritzalis ${ }^{20}$, Ian Harris ${ }^{21}$, Judith Hauck $^{22}$, Vanessa Haverd ${ }^{23}$, Mario Hoppema ${ }^{22}$, Kees Klein Goldewijk ${ }^{24}$, Atul K. Jain ${ }^{25}$, Etsushi Kato $^{26}$, Arne Körtzinger ${ }^{27}$, Peter Landschützer ${ }^{28}$, Nathalie Lefèvre ${ }^{29}$, Andrew Lenton ${ }^{30}$, Sebastian Lienert $^{31,32}$, Danica Lombardozzi ${ }^{33}$, Joe R. Melton ${ }^{34}$, Nicolas Metzl ${ }^{29}$, Frank Millero ${ }^{35}$, Pedro M. S. Monteiro ${ }^{36}$, David R. Munro ${ }^{37}$, Julia E. M. S. Nabel ${ }^{28}$, Shin-ichiro Nakaoka ${ }^{38}$, Kevin O'Brien ${ }^{39}$, Are Olsen ${ }^{40}$, Abdirahman M. Omar ${ }^{40}$, Tsuneo Ono ${ }^{41}$, Denis Pierrot ${ }^{12,13}$,

Benjamin Poulter ${ }^{42,43}$, Christian Rödenbeck ${ }^{44}$, Joe Salisbury ${ }^{45}$, Ute Schuster ${ }^{4}$, Jörg Schwinger ${ }^{46}$, Roland Séférian ${ }^{17}$, Ingunn Skjelvan ${ }^{46}$, Benjamin D. Stocker ${ }^{47}$, Adrienne J. Sutton ${ }^{39,10}$, Taro Takahashi ${ }^{48}$, Hanqin Tian ${ }^{49}$, Bronte Tilbrook ${ }^{50}$, Ingrid T. van der Laan-Luijkx ${ }^{51}$, Guido R. van der Wer ${ }^{52}$, Nicolas Viovy ${ }^{14}$, Anthony P. Walker ${ }^{53}$, Andrew J. Wiltshire ${ }^{54}$, and Sönke Zaehle ${ }^{44}$

${ }^{1}$ Tyndall Centre for Climate Change Research, University of East Anglia, Norwich Research Park, Norwich, NR4 7TJ, UK

${ }^{2}$ Center for International Climate and Environmental Research - Oslo (CICERO), Oslo, Norway

${ }^{3}$ Global Carbon Project, CSIRO Oceans and Atmosphere, GPO Box 3023, Canberra, ACT 2601, Australia

${ }^{4}$ College of Life and Environmental Sciences, University of Exeter, Exeter, EX4 4RJ, UK

${ }^{5}$ Centre for Ocean and Atmospheric Sciences, School of Environmental Sciences, University of East Anglia, Norwich Research Park, Norwich, NR4 7TJ, UK

${ }^{6}$ Carbon Dioxide Information Analysis Center (CDIAC), Oak Ridge National Laboratory, Oak Ridge, TN, USA

${ }^{7}$ National Oceanic \& Atmospheric Administration, Earth System Research Laboratory (NOAA/ESRL), Boulder, CO 80305, USA

${ }^{8}$ Woods Hole Research Center (WHRC), Falmouth, MA 02540, USA

${ }^{9}$ University of California, San Diego, Scripps Institution of Oceanography, La Jolla, CA 92093-0244, USA

${ }^{10}$ National Oceanic \& Atmospheric Administration/Pacific Marine Environmental Laboratory (NOAA/PMEL), 7600 Sand Point Way NE, Seattle, WA 98115, USA

${ }^{11}$ Karlsruhe Institute of Technology, Institute of Meteorology and Climate Research/Atmospheric Environmental Research, 82467 Garmisch-Partenkirchen, Germany

${ }^{12}$ Cooperative Institute for Marine and Atmospheric Studies, Rosenstiel School for Marine and Atmospheric Science, University of Miami, Miami, FL 33149, USA

${ }^{13}$ National Oceanic \& Atmospheric Administration/Atlantic Oceanographic \& Meteorological Laboratory (NOAA/AOML), Miami, FL 33149, USA

${ }^{14}$ Laboratoire des Sciences du Climat et de l'Environnement, Institut Pierre-Simon Laplace, CEA-CNRS-UVSQ, CE Orme des Merisiers, 91191 Gif sur Yvette CEDEX, France

${ }^{15}$ Department of Geographical Sciences, University of Maryland, College Park, MD 20742, USA

${ }^{16}$ National Institute of Water and Atmospheric Research (NIWA), Dunedin 9054, New Zealand

${ }^{17}$ Centre National de Recherche Météorologique, Unite mixte de recherche 3589 Météo-France/CNRS, 42 Avenue Gaspard Coriolis, 31100 Toulouse, France

${ }^{18}$ Woods Hole Oceanographic Institution (WHOI), Woods Hole, MA 02543, USA

${ }^{19}$ College of Engineering, Mathematics and Physical Sciences, University of Exeter, Exeter, EX4 4QF, UK

${ }^{20}$ Flanders Marine Institute, InnovOcean, Wandelaarkaai 7, 8400 Ostend, Belgium

${ }^{21}$ Climatic Research Unit, University of East Anglia, Norwich Research Park, Norwich, NR4 7TJ, UK 
${ }^{22}$ Alfred Wegener Institute Helmholtz Centre for Polar and Marine Research, Postfach 120161, 27515 Bremerhaven, Germany

${ }^{23}$ CSIRO Oceans and Atmosphere, GPO Box 1700, Canberra, ACT 2601, Australia

${ }^{24}$ PBL Netherlands Environmental Assessment Agency, The Hague/Bilthoven and Utrecht University, Utrecht, the Netherlands

${ }^{25}$ Department of Atmospheric Sciences, University of Illinois, Urbana, IL 61821, USA

${ }^{26}$ Institute of Applied Energy (IAE), Minato-ku, Tokyo 105-0003, Japan

${ }^{27}$ GEOMAR Helmholtz Centre for Ocean Research Kiel, Düsternbrooker Weg 20, 24105 Kiel, Germany

${ }^{28}$ Max Planck Institute for Meteorology, Bundesstr. 53, 20146 Hamburg, Germany

${ }^{29}$ Sorbonne Universités (UPMC, Univ Paris 06), CNRS, IRD, MNHN, LOCEAN/IPSL Laboratory, 75252 Paris, France

${ }^{30}$ CSIRO Oceans and Atmosphere, P.O. Box 1538, Hobart, TAS, Australia

${ }^{31}$ Climate and Environmental Physics, Physics Institute, University of Bern, Bern, Switzerland

${ }^{32}$ Oeschger Centre for Climate Change Research, University of Bern, Bern, Switzerland

${ }^{33}$ National Center for Atmospheric Research, Climate and Global Dynamics, Terrestrial Sciences Section, Boulder, CO 80305, USA

${ }^{34}$ Climate Research Division, Environment and Climate Change Canada, Victoria, Canada

${ }^{35}$ Department of Ocean Sciences, RSMAS/MAC, University of Miami, 4600 Rickenbacker Causeway, Miami, FL 33149, USA

${ }^{36}$ Ocean Systems and Climate, CSIR-CHPC, Cape Town, 7700, South Africa

${ }^{37}$ Department of Atmospheric and Oceanic Sciences and Institute of Arctic and Alpine Research, University of Colorado, Campus Box 450, Boulder, CO 80309-0450, USA

${ }^{38}$ Center for Global Environmental Research, National Institute for Environmental Studies (NIES), 16-2 Onogawa, Tsukuba, Ibaraki 305-8506, Japan

${ }^{39}$ Joint Institute for the Study of the Atmosphere and Ocean, University of Washington, Seattle, WA 98195, USA

${ }^{40}$ Geophysical Institute, University of Bergen and Bjerknes Centre for Climate Research, Allégaten 70, 5007 Bergen, Norway

${ }^{41}$ National Research Institute for Far Sea Fisheries, Japan Fisheries Research and Education Agency 2-12-4

Fukuura, Kanazawa-Ku, Yokohama 236-8648, Japan

${ }^{42}$ NASA Goddard Space Flight Center, Biospheric Science Laboratory, Greenbelt, MD 20771, USA

${ }^{43}$ Department of Ecology, Montana State University, Bozeman, MT 59717, USA

${ }^{44}$ Max Planck Institute for Biogeochemistry, P.O. Box 600164, Hans-Knöll-Str. 10, 07745 Jena, Germany

${ }^{45}$ University of New Hampshire, Ocean Process Analysis Laboratory, 161 Morse Hall, 8 College Road, Durham, NH 03824, USA

${ }^{46}$ Uni Research Climate, Bjerknes Centre for Climate Research, Nygårdsgaten 112, 5008 Bergen, Norway

${ }^{47}$ Imperial College London, Life Science Department, Silwood Park, Ascot, Berkshire, SL5 7PY, UK

${ }^{48}$ Lamont-Doherty Earth Observatory of Columbia University, Palisades, NY 10964, USA

${ }^{49}$ School of Forestry and Wildlife Sciences, Auburn University, 602 Ducan Drive, Auburn, AL 36849, USA

${ }^{50}$ CSIRO Oceans and Atmosphere and Antarctic Climate and Ecosystems Cooperative Research Centre, Hobart, TAS, Australia

${ }^{51}$ Department of Meteorology and Air Quality, Wageningen University \& Research, P.O. Box 47, 6700AA Wageningen, the Netherlands

${ }^{52}$ Faculty of Earth and Life Sciences, VU University Amsterdam, Amsterdam, the Netherlands

${ }^{53}$ Environmental Sciences Division \& Climate Change Science Institute, Oak Ridge National Laboratory, Oak Ridge, TN, USA

${ }^{54}$ Met Office Hadley Centre, FitzRoy Road, Exeter, EX1 3PB, UK

Correspondence to: Corinne Le Quéré (c.lequere@uea.ac.uk)

Received: 5 October 2016 - Published in Earth Syst. Sci. Data Discuss.: 12 October 2016

Revised: 12 October 2016 - Accepted: 18 October 2016 - Published: 14 November 2016

Abstract. Accurate assessment of anthropogenic carbon dioxide $\left(\mathrm{CO}_{2}\right)$ emissions and their redistribution among the atmosphere, ocean, and terrestrial biosphere - the "global carbon budget" - is important to better understand the global carbon cycle, support the development of climate policies, and project future climate 
change. Here we describe data sets and methodology to quantify all major components of the global carbon budget, including their uncertainties, based on the combination of a range of data, algorithms, statistics, and model estimates and their interpretation by a broad scientific community. We discuss changes compared to previous estimates and consistency within and among components, alongside methodology and data limitations. $\mathrm{CO}_{2}$ emissions from fossil fuels and industry $\left(E_{\mathrm{FF}}\right)$ are based on energy statistics and cement production data, respectively, while emissions from land-use change $\left(E_{\mathrm{LUC}}\right)$, mainly deforestation, are based on combined evidence from land-cover change data, fire activity associated with deforestation, and models. The global atmospheric $\mathrm{CO}_{2}$ concentration is measured directly and its rate of growth $\left(G_{\mathrm{ATM}}\right)$ is computed from the annual changes in concentration. The mean ocean $\mathrm{CO}_{2}$ sink $\left(S_{\text {OCEAN }}\right)$ is based on observations from the 1990 s, while the annual anomalies and trends are estimated with ocean models. The variability in $S_{\text {OCEAN }}$ is evaluated with data products based on surveys of ocean $\mathrm{CO}_{2}$ measurements. The global residual terrestrial $\mathrm{CO}_{2}$ sink $\left(S_{\mathrm{LAND}}\right)$ is estimated by the difference of the other terms of the global carbon budget and compared to results of independent dynamic global vegetation models. We compare the mean land and ocean fluxes and their variability to estimates from three atmospheric inverse methods for three broad latitude bands. All uncertainties are reported as $\pm 1 \sigma$, reflecting the current capacity to characterise the annual estimates of each component of the global carbon budget. For the last decade available (2006-2015), $E_{\mathrm{FF}}$ was $9.3 \pm 0.5 \mathrm{GtC} \mathrm{yr}^{-1}, E_{\mathrm{LUC}} 1.0 \pm 0.5 \mathrm{GtC} \mathrm{yr}^{-1}$, $G_{\text {ATM }} 4.5 \pm 0.1 \mathrm{GtC} \mathrm{yr}^{-1}, S_{\text {OCEAN }} 2.6 \pm 0.5 \mathrm{GtC} \mathrm{yr}^{-1}$, and $S_{\text {LAND }} 3.1 \pm 0.9 \mathrm{GtC} \mathrm{yr}^{-1}$. For year 2015 alone, the growth in $E_{\mathrm{FF}}$ was approximately zero and emissions remained at $9.9 \pm 0.5 \mathrm{GtC} \mathrm{yr}^{-1}$, showing a slowdown in growth of these emissions compared to the average growth of $1.8 \% \mathrm{yr}^{-1}$ that took place during 2006-2015. Also, for $2015, E_{\mathrm{LUC}}$ was $1.3 \pm 0.5 \mathrm{GtC} \mathrm{yr}^{-1}, G_{\mathrm{ATM}}$ was $6.3 \pm 0.2 \mathrm{GtC} \mathrm{yr}^{-1}, S_{\text {OCEAN }}$ was $3.0 \pm 0.5 \mathrm{GtC} \mathrm{yr}^{-1}$, and $S_{\mathrm{LAND}}$ was $1.9 \pm 0.9 \mathrm{GtC} \mathrm{yr}^{-1}$. $G_{\mathrm{ATM}}$ was higher in 2015 compared to the past decade (2006-2015), reflecting a smaller $S_{\text {LAND }}$ for that year. The global atmospheric $\mathrm{CO}_{2}$ concentration reached $399.4 \pm 0.1 \mathrm{ppm}$ averaged over 2015. For 2016, preliminary data indicate the continuation of low growth in $E_{\mathrm{FF}}$ with $+0.2 \%$ (range of -1.0 to $+1.8 \%$ ) based on national emissions projections for China and USA, and projections of gross domestic product corrected for recent changes in the carbon intensity of the economy for the rest of the world. In spite of the low growth of $E_{\mathrm{FF}}$ in 2016, the growth rate in atmospheric $\mathrm{CO}_{2}$ concentration is expected to be relatively high because of the persistence of the smaller residual terrestrial sink ( $S_{\text {LAND }}$ ) in response to El Niño conditions of 2015-2016. From this projection of $E_{\mathrm{FF}}$ and assumed constant $E_{\mathrm{LUC}}$ for 2016, cumulative emissions of $\mathrm{CO}_{2}$ will reach $565 \pm 55 \mathrm{GtC}\left(2075 \pm 205 \mathrm{GtCO}_{2}\right)$ for $1870-2016$, about $75 \%$ from $E_{\mathrm{FF}}$ and $25 \%$ from $E_{\mathrm{LUC}}$. This living data update documents changes in the methods and data sets used in this new carbon budget compared with previous publications of this data set (Le Quéré et al., 2015b, a, 2014, 2013). All observations presented here can be downloaded from the Carbon Dioxide Information Analysis Center (doi:10.3334/CDIAC/GCP_2016).

\section{Introduction}

The concentration of carbon dioxide $\left(\mathrm{CO}_{2}\right)$ in the atmosphere has increased from approximately 277 parts per million (ppm) in 1750 (Joos and Spahni, 2008), the beginning of the industrial era, to $399.4 \pm 0.1 \mathrm{ppm}$ in 2015 (Dlugokencky and Tans, 2016). The Mauna Loa station, which holds the longest running record of direct measurements of atmospheric $\mathrm{CO}_{2}$ concentration (Tans and Keeling, 2014), went above $400 \mathrm{ppm}$ for the first time in May 2013 (Scripps, 2013). The global monthly average concentration was above $400 \mathrm{ppm}$ in March through May 2015 and again since November 2015 (Dlugokencky and Tans, 2016; Fig. 1). The atmospheric $\mathrm{CO}_{2}$ increase above pre-industrial levels was, initially, primarily caused by the release of carbon to the atmosphere from deforestation and other land-use-change activities (Ciais et al., 2013). While emissions from fossil fuels started before the industrial era, they only became the dominant source of anthropogenic emissions to the atmosphere from around
1920, and their relative share has continued to increase until present. Anthropogenic emissions occur on top of an active natural carbon cycle that circulates carbon between the reservoirs of the atmosphere, ocean, and terrestrial biosphere on timescales from sub-daily to millennia, while exchanges with geologic reservoirs occur at longer timescales (Archer et al., 2009).

The global carbon budget presented here refers to the mean, variations, and trends in the perturbation of $\mathrm{CO}_{2}$ in the atmosphere, referenced to the beginning of the industrial era. It quantifies the input of $\mathrm{CO}_{2}$ to the atmosphere by emissions from human activities, the growth rate of atmospheric $\mathrm{CO}_{2}$ concentration, and the resulting changes in the storage of carbon in the land and ocean reservoirs in response to increasing atmospheric $\mathrm{CO}_{2}$ levels, climate change and variability, and other anthropogenic and natural changes (Fig. 2). An understanding of this perturbation budget over time and the underlying variability and trends of the natural carbon cycle is necessary to understand the response of natural sinks 


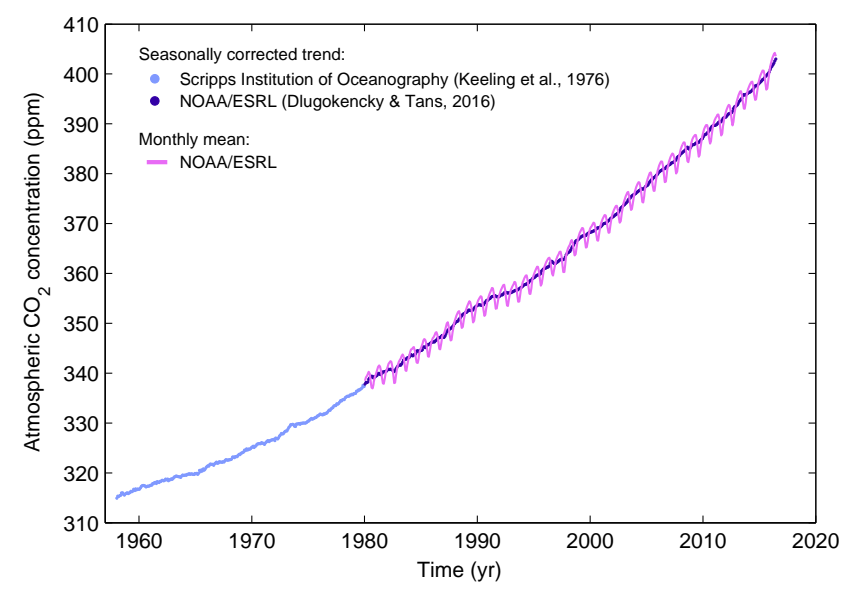

Figure 1. Surface average atmospheric $\mathrm{CO}_{2}$ concentration, deseasonalised (ppm). The 1980-2016 monthly data are from NOAA/ESRL (Dlugokencky and Tans, 2016) and are based on an average of direct atmospheric $\mathrm{CO}_{2}$ measurements from multiple stations in the marine boundary layer (Masarie and Tans, 1995). The 1958-1979 monthly data are from the Scripps Institution of Oceanography, based on an average of direct atmospheric $\mathrm{CO}_{2}$ measurements from the Mauna Loa and South Pole stations (Keeling et al., 1976). To take into account the difference of mean $\mathrm{CO}_{2}$ between the NOAA/ESRL and the Scripps station networks used here, the Scripps surface average (from two stations) was harmonised to match the NOAA/ESRL surface average (from multiple stations) by adding the mean difference of $0.542 \mathrm{ppm}$, calculated here from overlapping data during 1980-2012. The mean seasonal cycle is also shown from 1980 (in pink).

to changes in climate, $\mathrm{CO}_{2}$, and land-use-change drivers, and the permissible emissions for a given climate stabilisation target.

The components of the $\mathrm{CO}_{2}$ budget that are reported annually in this paper include separate estimates for the $\mathrm{CO}_{2}$ emissions from (1) fossil fuel combustion and oxidation and cement production $\left(E_{\mathrm{FF}} ; \mathrm{GtC} \mathrm{yr}^{-1}\right)$ and (2) the emissions resulting from deliberate human activities on land leading to land-use change $\left(E_{\mathrm{LUC}} ; \mathrm{GtC} \mathrm{yr}^{-1}\right)$, as well as their partitioning among (3) the growth rate of atmospheric $\mathrm{CO}_{2}$ concentration $\left(G_{\mathrm{ATM}} ; \mathrm{GtC} \mathrm{yr}^{-1}\right)$, and the uptake of $\mathrm{CO}_{2}$ by the " $\mathrm{CO}_{2}$ sinks" in (4) the ocean $\left(S_{\text {OCEAN }} ; \mathrm{GtC} \mathrm{yr}^{-1}\right)$ and (5) on

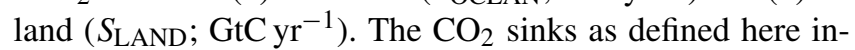
clude the response of the land and ocean to elevated $\mathrm{CO}_{2}$ and changes in climate and other environmental conditions. The global emissions and their partitioning among the atmosphere, ocean, and land are in balance:

$E_{\mathrm{FF}}+E_{\mathrm{LUC}}=G_{\mathrm{ATM}}+S_{\mathrm{OCEAN}}+S_{\mathrm{LAND}}$

$G_{\text {ATM }}$ is usually reported in $\mathrm{ppm} \mathrm{yr}^{-1}$, which we convert to units of carbon mass per year, $\mathrm{GtC} \mathrm{yr}^{-1}$, using $1 \mathrm{ppm}=2.12 \mathrm{GtC}$ (Ballantyne et al., 2012; Prather et al., 2012; Table 1). We also include a quantification of $E_{\mathrm{FF}}$ by

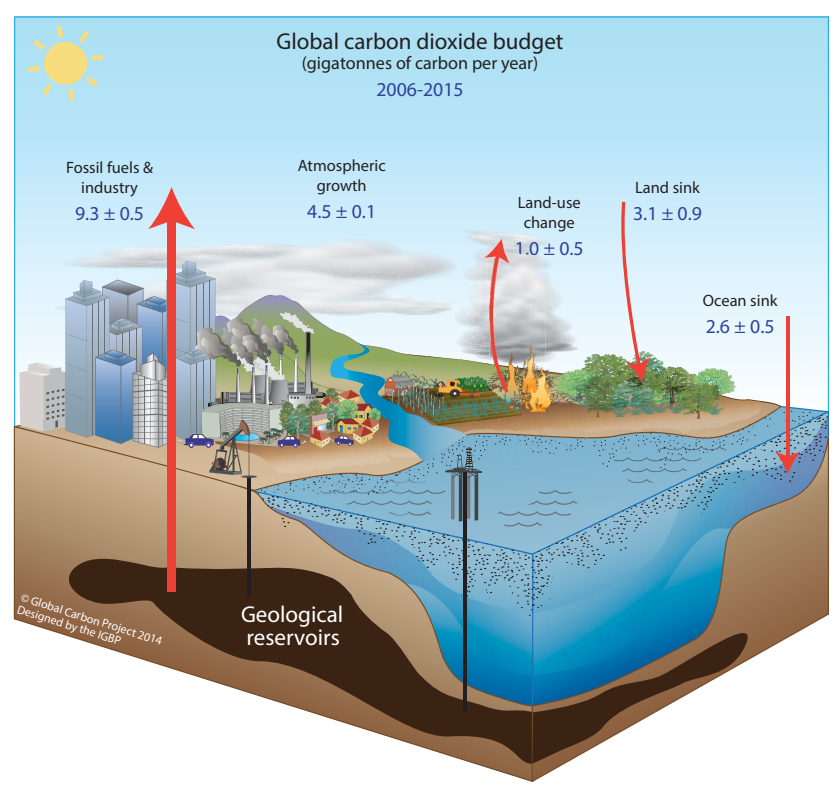

Figure 2. Schematic representation of the overall perturbation of the global carbon cycle caused by anthropogenic activities, averaged globally for the decade 2006-2015. The arrows represent emission from fossil fuels and industry $\left(E_{\mathrm{FF}}\right)$, emissions from deforestation and other land-use change $\left(E_{\mathrm{LUC}}\right)$, the growth rate in atmospheric $\mathrm{CO}_{2}$ concentration $\left(G_{\mathrm{ATM}}\right)$, and the uptake of carbon by the "sinks" in the ocean $\left(S_{\text {OCEAN }}\right)$ and land $\left(S_{\text {LAND }}\right)$ reservoirs.

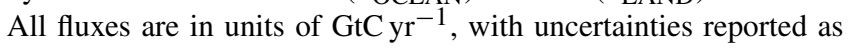
$\pm 1 \sigma$ ( $68 \%$ confidence that the real value lies within the given interval) as described in the text. This figure is an update of one prepared by the International Geosphere-Biosphere Programme for the Global Carbon Project (GCP), first presented in Le Quéré (2009).

country, computed with both territorial and consumptionbased accounting (see Sect. 2).

Equation (1) partly omits two kinds of processes. The first is the net input of $\mathrm{CO}_{2}$ to the atmosphere from the chemical oxidation of reactive carbon-containing gases from sources other than the combustion of fossil fuels (e.g. fugitive anthropogenic $\mathrm{CH}_{4}$ emissions, industrial processes, and biogenic emissions from changes in vegetation, fires, wetlands), primarily methane $\left(\mathrm{CH}_{4}\right)$, carbon monoxide $(\mathrm{CO})$, and volatile organic compounds such as isoprene and terpene (GonzalezGaya et al., 2016). CO emissions are currently implicit in $E_{\mathrm{FF}}$, while fugitive anthropogenic $\mathrm{CH}_{4}$ emissions are not and thus their inclusion would result in a small increase in $E_{\mathrm{FF}}$. The second is the anthropogenic perturbation to carbon cycling in terrestrial freshwaters, estuaries, and coastal areas, which modifies lateral fluxes from land ecosystems to the open ocean; the evasion of $\mathrm{CO}_{2}$ flux from rivers, lakes, and estuaries to the atmosphere; and the net air-sea anthropogenic $\mathrm{CO}_{2}$ flux of coastal areas (Regnier et al., 2013). The inclusion of freshwater fluxes of anthropogenic $\mathrm{CO}_{2}$ would affect the estimates of, and partitioning between, $S_{\text {LAND }}$ and $S_{\text {OCEAN }}$ in Eq. (1) in complementary ways, but it would not 
Table 1. Factors used to convert carbon in various units (by convention, unit $1=$ unit $2 \cdot$ conversion).

\begin{tabular}{llrl}
\hline Unit 1 & Unit 2 & Conversion & Source \\
\hline GtC (gigatonnes of carbon) & $\mathrm{ppm}^{\text {(parts per million) }}{ }^{\mathrm{a}}$ & $2.12^{\mathrm{b}}$ & Ballantyne et al. (2012) \\
$\mathrm{GtC}$ (gigatonnes of carbon) & PgC (petagrams of carbon) & 1 & SI unit conversion \\
$\mathrm{GtCO}_{2}$ (gigatonnes of carbon dioxide) & $\mathrm{GtC}$ (gigatonnes of carbon) & 3.664 & $44.01 / 12.011$ in mass equivalent \\
$\mathrm{GtC}$ (gigatonnes of carbon) & MtC (megatonnes of carbon) & 1000 & SI unit conversion \\
\hline
\end{tabular}

a Measurements of atmospheric $\mathrm{CO}_{2}$ concentration have units of dry-air mole fraction. "ppm" is an abbreviation for micromole per mole of dry air. b The use of a factor of 2.12 assumes that all the atmosphere is well mixed within one year. In reality, only the troposphere is well mixed and the growth rate of $\mathrm{CO}_{2}$ concentration in the less well-mixed stratosphere is not measured by sites from the NOAA network. Using a factor of 2.12 makes the approximation that the growth rate of $\mathrm{CO}_{2}$ concentration in the stratosphere equals that of the troposphere on a yearly basis.

affect the other terms. These flows are omitted in the absence of annual information on the natural vs. anthropogenic perturbation terms of these loops of the carbon cycle, and they are discussed in Sect. 2.7.

The $\mathrm{CO}_{2}$ budget has been assessed by the Intergovernmental Panel on Climate Change (IPCC) in all assessment reports (Ciais et al., 2013; Denman et al., 2007; Prentice et al., 2001; Schimel et al., 1995; Watson et al., 1990), as well as by others (e.g. Ballantyne et al., 2012). These assessments included budget estimates for the decades of the 1980s and 1990s (Denman et al., 2007) and, most recently, the period 2002-2011 (Ciais et al., 2013). The IPCC methodology has been adapted and used by the Global Carbon Project (GCP, http://www.globalcarbonproject.org), which has coordinated a cooperative community effort for the annual publication of global carbon budgets up to year 2005 (Raupach et al., 2007; including fossil emissions only), year 2006 (Canadell et al., 2007), year 2007 (published online; GCP, 2007), year 2008 (Le Quéré et al., 2009), year 2009 (Friedlingstein et al., 2010), year 2010 (Peters et al., 2012b), year 2012 (Le Quéré et al., 2013; Peters et al., 2013), year 2013 (Le Quéré et al., 2014), year 2014 (Friedlingstein et al., 2014; Le Quéré et al., 2015b), and most recently year 2015 (Jackson et al., 2016; Le Quéré et al., 2015a). Each of these papers updated previous estimates with the latest available information for the entire time series. From 2008, these publications projected fossil fuel emissions for one additional year.

We adopt a range of \pm 1 standard deviation $(\sigma)$ to report the uncertainties in our estimates, representing a likelihood of $68 \%$ that the true value will be within the provided range if the errors have a Gaussian distribution. This choice reflects the difficulty of characterising the uncertainty in the $\mathrm{CO}_{2}$ fluxes between the atmosphere and the ocean and land reservoirs individually, particularly on an annual basis, as well as the difficulty of updating the $\mathrm{CO}_{2}$ emissions from land-use change. A likelihood of $68 \%$ provides an indication of our current capability to quantify each term and its uncertainty given the available information. For comparison, the Fifth Assessment Report of the IPCC (AR5) generally reported a likelihood of $90 \%$ for large data sets whose uncertainty is well characterised, or for long time intervals less affected by year-to-year variability. Our $68 \%$ uncertainty value is near the $66 \%$ which the IPCC characterises as "likely" for values falling into the $\pm 1 \sigma$ interval. The uncertainties reported here combine statistical analysis of the underlying data and expert judgement of the likelihood of results lying outside this range. The limitations of current information are discussed in the paper and have been examined in detail elsewhere (Ballantyne et al., 2015).

All quantities are presented in units of gigatonnes of carbon $\left(\mathrm{GtC}, 10^{15} \mathrm{gC}\right)$, which is the same as petagrams of carbon $\left(\mathrm{PgC}\right.$; Table 1). Units of gigatonnes of $\mathrm{CO}_{2}$ (or billion tonnes of $\mathrm{CO}_{2}$ ) used in policy are equal to 3.664 multiplied by the value in units of GtC.

This paper provides a detailed description of the data sets and methodology used to compute the global carbon budget estimates for the period pre-industrial (1750) to 2015 and in more detail for the period 1959 to 2015. We also provide decadal averages starting in 1960 including the last decade (2006-2015), results for the year 2015, and a projection for year 2016. Finally, we provide cumulative emissions from fossil fuels and land-use change since year 1750 , the pre-industrial period, and since year 1870, the reference year for the cumulative carbon estimate used by the IPCC (AR5) based on the availability of global temperature data (Stocker et al., 2013). This paper will be updated every year using the format of "living data" to keep a record of budget versions and the changes in new data, revision of data, and changes in methodology that lead to changes in estimates of the carbon budget. Additional materials associated with the release of each new version will be posted at the Global Carbon Project (GCP) website (http://www.globalcarbonproject.org/carbonbudget), with fossil fuel emissions also available through the Global Carbon Atlas (http://www.globalcarbonatlas.org). With this approach, we aim to provide the highest transparency and traceability in the reporting of $\mathrm{CO}_{2}$, the key driver of climate change.

\section{Methods}

Multiple organisations and research groups around the world generated the original measurements and data used to complete the global carbon budget. The effort presented here is 
Table 2. How to cite the individual components of the global carbon budget presented here.

\begin{tabular}{|c|c|}
\hline Component & Primary reference \\
\hline $\begin{array}{l}\text { Global emissions from fossil fuels and industry }\left(E_{\mathrm{FF}}\right) \text {, } \\
\text { total and by fuel type }\end{array}$ & $\begin{array}{l}\text { Boden and Andres (2016; CDIAC; http://cdiac.ornl. } \\
\text { gov/trends/emis/meth_reg.html) }\end{array}$ \\
\hline $\begin{array}{l}\text { National territorial emissions from fossil fuels and in- } \\
\text { dustry }\left(E_{\mathrm{FF}}\right)\end{array}$ & $\begin{array}{l}\text { CDIAC source: Boden and Andres (2016; as above) } \\
\text { UNFCCC source: (2016; http://unfccc.int/national_ } \\
\text { reports/annex_i_ghg_inventories/national_inventories_ } \\
\text { submissions/items/8108.php; last access: June 2016) }\end{array}$ \\
\hline $\begin{array}{l}\text { National consumption-based emissions from fossil fu- } \\
\text { els and industry }\left(E_{\mathrm{FF}}\right) \text { by country (consumption) }\end{array}$ & Peters et al. (2011b) updated as described in this paper \\
\hline Land-use-change emissions ( $\left.E_{\mathrm{LUC}}\right)$ & $\begin{array}{l}\text { Houghton et al. (2012) combined with Giglio et } \\
\text { al. (2013) }\end{array}$ \\
\hline Growth rate in atmospheric $\mathrm{CO}_{2}$ concentration $\left(G_{\mathrm{ATM}}\right)$ & $\begin{array}{l}\text { Dlugokencky and Tans (2016; NOAA/ESRL: http: } \\
\text { //www.esrl.noaa.gov/gmd/ccgg/trends/global.html; last } \\
\text { access: July 2016) }\end{array}$ \\
\hline Ocean and land $\mathrm{CO}_{2}$ sinks ( $S_{\text {OCEAN }}$ and $\left.S_{\text {LAND }}\right)$ & $\begin{array}{l}\text { This paper for } S_{\text {OCEAN }} \text { and } S_{\text {LAND }} \text { and references in } \\
\text { Table } 6 \text { for individual models }\end{array}$ \\
\hline
\end{tabular}

thus mainly one of synthesis, where results from individual groups are collated, analysed, and evaluated for consistency. We facilitate access to original data with the understanding that primary data sets will be referenced in future work (see Table 2 for how to cite the data sets). Descriptions of the measurements, models, and methodologies follow below and in-depth descriptions of each component are described elsewhere.

This is the 11th version of the global carbon budget and the fifth revised version in the format of a living data update. It builds on the latest published global carbon budget of Le Quéré et al. (2015a). The main changes are (1) the inclusion of data to year 2015 (inclusive) and a projection for fossil fuel emissions for year 2016; (2) the introduction of a projection for the full carbon budget for year 2016 using our fossil fuel projection, combined with preliminary data (Dlugokencky and Tans, 2016) and analysis by others (Betts et al., 2016) of the growth rate in atmospheric $\mathrm{CO}_{2}$ concentration; and (3) the use of BP data from 1990 (BP, 2016b) to estimate emissions in China to ensure all recent revisions in Chinese statistics are incorporated. The main methodological differences between annual carbon budgets are summarised in Table 3.

\section{1 $\mathrm{CO}_{2}$ emissions from fossil fuels and industry ( $\left.E_{\mathrm{FF}}\right)$}

\subsubsection{Emissions from fossil fuels and industry and their uncertainty}

The calculation of global and national $\mathrm{CO}_{2}$ emissions from fossil fuels, including gas flaring and cement production $\left(E_{\mathrm{FF}}\right)$, relies primarily on energy consumption data, specifically data on hydrocarbon fuels, collated and archived by several organisations (Andres et al., 2012). These include the Carbon Dioxide Information Analysis Center (CDIAC), the International Energy Agency (IEA), the United Nations (UN), the United States Department of Energy (DoE) Energy Information Administration (EIA), and more recently also the Planbureau voor de Leefomgeving (PBL) Netherlands Environmental Assessment Agency. Where available, we use national emissions estimated by the countries themselves and reported to the UNFCCC for the period 19902014 (40 countries). We assume that national emissions reported to the UNFCCC are the most accurate because national experts have access to additional and country-specific information, and because these emission estimates are periodically audited for each country through an established international methodology overseen by the UNFCCC. We also use global and national emissions estimated by CDIAC (Boden and Andres, 2016). The CDIAC emission estimates are the only data set that extends back in time to 1751 with consistent and well-documented emissions from fossil fuels, cement production, and gas flaring for all countries and their uncertainty (Andres et al., 2014, 2012, 1999); this makes the data set a unique resource for research of the carbon cycle during the fossil fuel era.

The global emissions presented here are based on CDIAC's analysis, which provides an internally consistent global estimate including bunker fuels, minimising the effects of lower-quality energy trade data. Thus, the comparison of global emissions with previous annual carbon budgets is not influenced by the use of national data from UNFCCC reports.

During the period 1959-2013, the emissions from fossil fuels estimated by CDIAC are based primarily on energy data provided by the UN Statistics Division (UN, 2015a, b; Ta- 


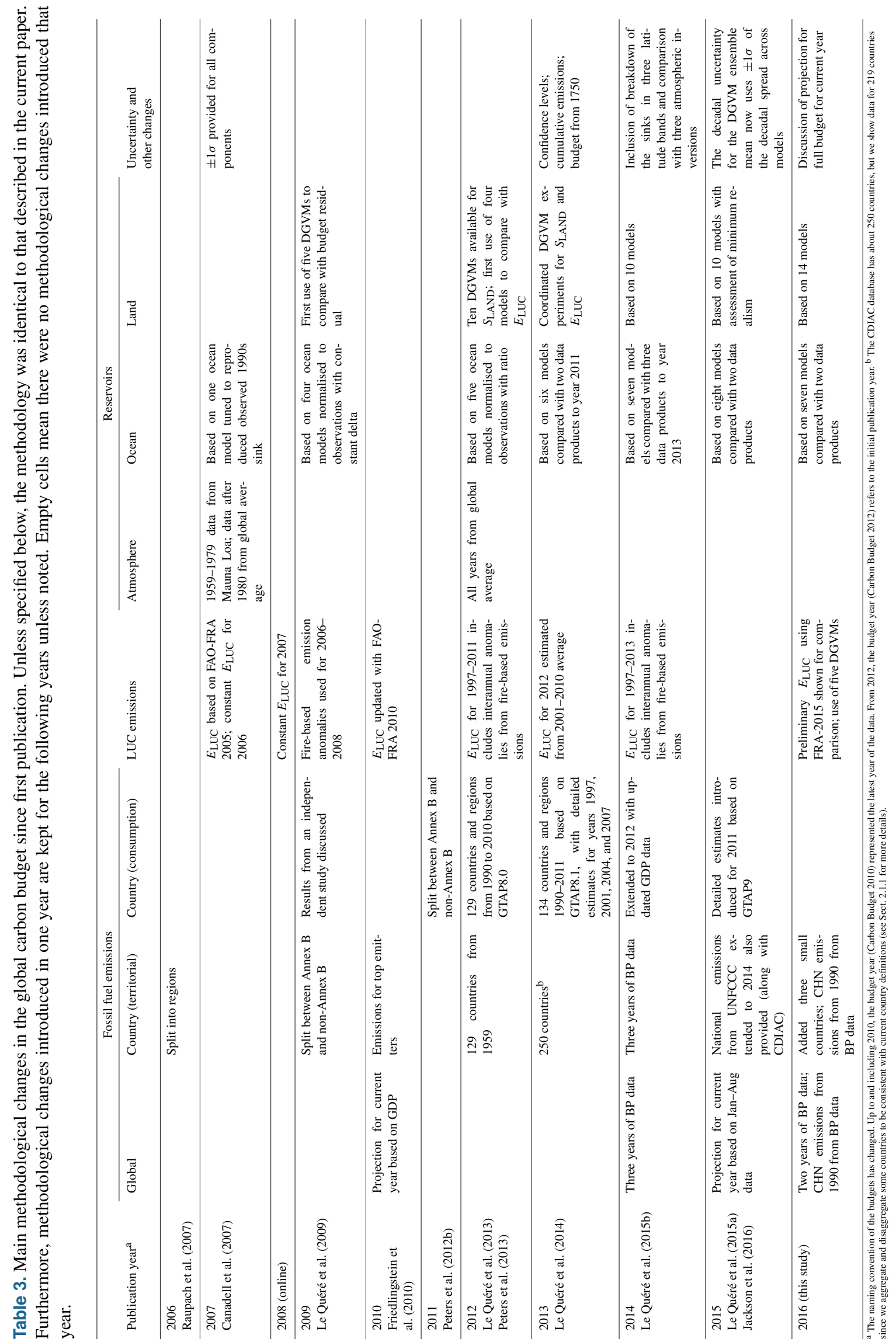


Table 4. Data sources used to compute each component of the global carbon budget.

\begin{tabular}{|c|c|c|c|}
\hline Component & Process & Data source & Data reference \\
\hline \multirow[t]{3}{*}{$\begin{array}{l}E_{\mathrm{FF}} \quad \text { (global and } \\
\text { CDIAC national) }\end{array}$} & $\begin{array}{l}\text { Fossil fuel combustion and gas } \\
\text { flaring }\end{array}$ & UN Statistics Division to 2013 & $\mathrm{UN}(2015 \mathrm{a}, \mathrm{b})$ \\
\hline & & BP for 2014-2015 & $\mathrm{BP}(\mathrm{BP}, 2016 \mathrm{~b})$ \\
\hline & Cement production & US Geological Survey & USGS $(2016 a, b)$ \\
\hline \multirow[t]{3}{*}{$E_{\mathrm{LUC}}$} & $\begin{array}{l}\text { Land-cover change (deforesta- } \\
\text { tion, afforestation, and forest } \\
\text { regrowth) }\end{array}$ & $\begin{array}{l}\text { Forest Resource Assessment } \\
\text { (FRA) of the Food and Agricul- } \\
\text { ture Organization (FAO) }\end{array}$ & FAO (2010) \\
\hline & $\begin{array}{l}\text { Wood harvest } \\
\text { Shifting agriculture }\end{array}$ & $\begin{array}{l}\text { FAO Statistics Division } \\
\text { FAO FRA and Statistics Divi- } \\
\text { sion }\end{array}$ & $\begin{array}{l}\text { FAOSTAT (2010) } \\
\text { FAO (2010) } \\
\text { FAOSTAT }(2010)\end{array}$ \\
\hline & $\begin{array}{l}\text { Interannual variability from } \\
\text { peat fires and climate-land } \\
\text { management interactions } \\
(1997-2013)\end{array}$ & $\begin{array}{l}\text { Global Fire Emissions } \\
\text { Database (GFED4) }\end{array}$ & Giglio et al. (2013) \\
\hline \multirow[t]{2}{*}{$G_{\mathrm{ATM}}$} & $\begin{array}{l}\text { Change in atmospheric } \mathrm{CO}_{2} \\
\text { concentration }\end{array}$ & $\begin{array}{l}\text { 1959-1980: } \mathrm{CO}_{2} \text { Program at } \\
\text { Scripps Institution of Oceanog- } \\
\text { raphy and other research groups }\end{array}$ & Keeling et al. (1976) \\
\hline & & $\begin{array}{l}\text { 1980-2015: US National } \\
\text { Oceanic and Atmospheric } \\
\text { Administration Earth System } \\
\text { Research Laboratory }\end{array}$ & $\begin{array}{l}\text { Dlugokencky and Tans (2016) } \\
\text { Ballantyne et al. (2012) }\end{array}$ \\
\hline \multirow[t]{2}{*}{$S_{\text {OCEAN }}$} & Uptake of anthropogenic $\mathrm{CO}_{2}$ & $\begin{array}{l}\text { 1990-1999 average: indirect es- } \\
\text { timates based on CFCs, atmo- } \\
\text { spheric } \mathrm{O}_{2} \text {, and other tracer ob- } \\
\text { servations }\end{array}$ & $\begin{array}{l}\text { Manning and Keeling (2006) } \\
\text { McNeil et al. (2003) } \\
\text { Mikaloff Fletcher et al. (2006) } \\
\text { as assessed by the IPCC in Den- } \\
\text { man et al. (2007) }\end{array}$ \\
\hline & $\begin{array}{l}\text { Impact of increasing atmo- } \\
\text { spheric } \mathrm{CO}_{2} \text {, climate, and vari- } \\
\text { ability }\end{array}$ & Ocean models & Table 6 \\
\hline$S_{\text {LAND }}$ & $\begin{array}{l}\text { Response of land vegetation to } \\
\text { increasing atmospheric } \mathrm{CO}_{2} \\
\text { concentration, } \\
\text { climate and variability, and } \\
\text { other environmental changes }\end{array}$ & Budget residual & \\
\hline
\end{tabular}

ble 4). When necessary, fuel masses/volumes are converted to fuel energy content using coefficients provided by the UN and then to $\mathrm{CO}_{2}$ emissions using conversion factors that take into account the relationship between carbon content and energy (heat) content of the different fuel types (coal, oil, gas, gas flaring) and the combustion efficiency (to account, for example, for soot left in the combustor or fuel otherwise lost or discharged without oxidation). Most data on energy consumption and fuel quality (carbon content and heat content) are available at the country level (UN, 2015a). In general, $\mathrm{CO}_{2}$ emissions for equivalent primary energy consumption are about $30 \%$ higher for coal compared to oil, and $70 \%$ higher for coal compared to natural gas (Marland et al., 2007).
Recent revisions in energy data for China (Korsbakken et al., 2016) have not yet fully propagated to the UN energy statistics used by CDIAC but are available through the BP energy statistics (BP, 2016b). We thus use the BP energy statistics (BP, 2016b) and estimate the emissions by fuel type using the BP methodology (BP, 2016a) to be consistent with the format of the CDIAC data. Emissions in China calculated from the BP statistics differ from those provided by CDIAC emissions mostly between 1997 and 2009. The revised emissions are higher by $5 \%$ on average between 1990 and 2015 for a total additional emissions of $2.0 \mathrm{GtC}$ during that period (41.3 GtC using the BP statistics and methodology compared to 39.3 provided by CDIAC). The two estimates converge to similar values from 2011 onwards ( $<2 \%$ differ- 
ence). We propagate these new estimates for China through to the global total to ensure consistency.

Our emission totals for the UNFCCC-reporting countries were recorded as in the UNFCCC submissions, which have a slightly larger system boundary than CDIAC. Additional emissions come from carbonates other than in cement manufacture, and thus UNFCCC totals will be slightly higher than CDIAC totals in general, although there are multiple sources of differences. We use the CDIAC method to report emissions by fuel type (e.g. all coal oxidation is reported under "coal", regardless of whether oxidation results from combustion as an energy source), which differs slightly from UNFCCC.

For the most recent 1-2 years when the UNFCCC estimates (1 year) and UN statistics (2 years) used by CDIAC are not yet available, we generated preliminary estimates based on the BP annual energy review by applying the growth rates of energy consumption (coal, oil, gas) for 2015 to the national and global emissions from the UN national data in 2014, and for 2014 and 2015 to the CDIAC national and global emissions in 2013. BP's sources for energy statistics overlap with those of the UN data but are compiled more rapidly from about 70 countries covering about $96 \%$ of global emissions. We use the BP values only for the yearto-year rate of change, because the rates of change are less uncertain than the absolute values and to avoid discontinuities in the time series when linking the UN-based data with the BP data. These preliminary estimates are replaced by the more complete UNFCCC or CDIAC data based on UN statistics when they become available. Past experience and work by others (Andres et al., 2014; Myhre et al., 2009) show that projections based on the BP rate of change are within the uncertainty provided (see Sect. 3.2 and Supplement from Peters et al., 2013).

Estimates of emissions from cement production by CDIAC are based on data on growth rates of cement production from the US Geological Survey up to year 2013 (USGS, 2016a). For 2014 and 2015 we use estimates of cement production made by the USGS for the top 18 countries (representing $85 \%$ of global production; USGS, 2016b), while for all other countries we use the 2013 values (zero growth). Some fraction of the $\mathrm{CaO}$ and $\mathrm{MgO}$ in cement is returned to the carbonate form during cement weathering, but this is neglected here.

Estimates of emissions from gas flaring by CDIAC are calculated in a similar manner to those from solid, liquid, and gaseous fuels and rely on the UN energy statistics to supply the amount of flared or vented fuel. For the most recent 1-2 emission years, flaring is assumed constant from the most recent available year of data (2014 for countries that report to the UNFCCC, and 2013 for the remainder). The basic data on gas flaring report atmospheric losses during petroleum production and processing that have large uncertainty and do not distinguish between gas that is flared as $\mathrm{CO}_{2}$ or vented as $\mathrm{CH}_{4}$. Fugitive emissions of $\mathrm{CH}_{4}$ from the so-called upstream sector (e.g. coal mining and natural gas distribution) are not included in the accounts of $\mathrm{CO}_{2}$ emissions except to the extent that they are captured in the UN energy data and counted as gas "flared or lost".

The published CDIAC data set includes 255 countries and regions. This list includes countries that no longer exist, such as the USSR and East Pakistan. For the carbon budget, we reduce the list to 219 countries by reallocating emissions to the currently defined territories. This involved both aggregation and disaggregation, and does not change global emissions. Examples of aggregation include merging East and West Germany to the currently defined Germany. Examples of disaggregation include reallocating the emissions from the former USSR to the resulting independent countries. For disaggregation, we use the emission shares when the current territories first appeared. The disaggregated estimates should be treated with care when examining countries' emissions trends prior to their disaggregation. For the most recent years, 2014 and 2015, the BP statistics are more aggregated, but we retain the detail of CDIAC by applying the growth rates of each aggregated region in the BP data set to its constituent individual countries in CDIAC.

Estimates of $\mathrm{CO}_{2}$ emissions show that the global total of emissions is not equal to the sum of emissions from all countries. This is largely attributable to emissions that occur in international territory, in particular the combustion of fuels used in international shipping and aviation (bunker fuels), where the emissions are included in the global totals but are not attributed to individual countries. In practice, the emissions from international bunker fuels are calculated based on where the fuels were loaded, but they are not included with national emissions estimates. Other differences occur because globally the sum of imports in all countries is not equal to the sum of exports and because of inconsistent national reporting, differing treatment of oxidation of non-fuel uses of hydrocarbons (e.g. as solvents, lubricants, feedstocks), and changes in stock (Andres et al., 2012).

The uncertainty in the annual emissions from fossil fuels and industry for the globe has been estimated at $\pm 5 \%$ (scaled down from the published $\pm 10 \%$ at $\pm 2 \sigma$ to the use of $\pm 1 \sigma$ bounds reported here; Andres et al., 2012). This is consistent with a more detailed recent analysis of uncertainty of $\pm 8.4 \%$ at $\pm 2 \sigma$ (Andres et al., 2014) and at the high end of the range of $\pm 5-10 \%$ at $\pm 2 \sigma$ reported by Ballantyne et al. (2015). This includes an assessment of uncertainties in the amounts of fuel consumed, the carbon and heat contents of fuels, and the combustion efficiency. While we consider a fixed uncertainty of $\pm 5 \%$ for all years, in reality the uncertainty, as a percentage of the emissions, is growing with time because of the larger share of global emissions from non-Annex B countries (emerging economies and developing countries) with less precise statistical systems (Marland et al., 2009). For example, the uncertainty in Chinese emissions has been estimated at around $\pm 10 \%$ (for $\pm 1 \sigma$; Gregg et al., 2008), and important potential biases have been iden- 
tified suggesting China's emissions could be overestimated in published studies (Liu et al., 2015). Generally, emissions from mature economies with good statistical bases have an uncertainty of only a few percent (Marland, 2008). Further research is needed before we can quantify the time evolution of the uncertainty, as well as its temporal error correlation structure. We note that even if they are presented as $1 \sigma$ estimates, uncertainties in emissions are likely to be mainly country-specific systematic errors related to underlying biases of energy statistics and to the accounting method used by each country. We assign a medium confidence to the results presented here because they are based on indirect estimates of emissions using energy data (Durant et al., 2011). There is only limited and indirect evidence for emissions, although there is a high agreement among the available estimates within the given uncertainty (Andres et al., 2014, 2012), and emission estimates are consistent with a range of other observations (Ciais et al., 2013), even though their regional and national partitioning is more uncertain (Francey et al., 2013).

\subsubsection{Emissions embodied in goods and services}

National emission inventories take a territorial (production) perspective and "include greenhouse gas emissions and removals taking place within national territory and offshore areas over which the country has jurisdiction" (Rypdal et al., 2006). That is, emissions are allocated to the country where and when the emissions actually occur. The territorial emission inventory of an individual country does not include the emissions from the production of goods and services produced in other countries (e.g. food and clothes) that are used for consumption. Consumption-based emission inventories for an individual country are another attribution point of view that allocates global emissions to products that are consumed within a country; these inventories are conceptually calculated as the territorial emissions minus the "embedded" territorial emissions to produce exported products plus the emissions in other countries to produce imported products (consumption $=$ territorial - exports + imports $)$. The difference between the territorial- and consumption-based emission inventories is the net transfer (exports minus imports) of emissions from the production of internationally traded products. Consumption-based emission attribution results (e.g. Davis and Caldeira, 2010) provide additional information to territorial-based emissions that can be used to understand emission drivers (Hertwich and Peters, 2009), quantify emission transfers by the trade of products between countries (Peters et al., 2011b), and potentially design more effective and efficient climate policy (Peters and Hertwich, 2008).

We estimate consumption-based emissions from 1990 to 2014 by enumerating the global supply chain using a global model of the economic relationships between economic sectors within and between every country (Andrew and Peters, 2013; Peters et al., 2011a). Our analysis is based on the eco- nomic and trade data from the Global Trade and Analysis Project (GTAP; Narayanan et al., 2015), and we make detailed estimates for the years 1997 (GTAP version 5), 2001 (GTAP6), and 2004, 2007, and 2011 (GTAP9.1) (using the methodology of Peters et al., 2011b). The results cover 57 sectors and up to 141 countries and regions. The detailed results are then extended into an annual time series from 1990 to the latest year of the GDP data (2014 in this budget), using GDP data by expenditure in current exchange rate of US dollars (USD; from the UN National Accounts Main Aggregates Database; UN, 2015c) and time series of trade data from GTAP (based on the methodology in Peters et al., 2011b).

We estimate the sector-level $\mathrm{CO}_{2}$ emissions using our own calculations based on the GTAP data and methodology, include flaring and cement emissions from CDIAC, and then scale the national totals (excluding bunker fuels) to match the CDIAC estimates from the most recent carbon budget. We do not include international transportation in our estimates of national totals, but include them in the global total. The time series of trade data provided by GTAP covers the period 1995-2013 and our methodology uses the trade shares as this data set. For the period 1990-1994 we assume the trade shares of 1995, while for 2014 we assume the trade shares of 2013.

Comprehensive analysis of the uncertainty in consumption emissions accounts is still lacking in the literature, although several analyses of components of this uncertainty have been made (e.g. Dietzenbacher et al., 2012; Inomata and Owen, 2014; Karstensen et al., 2015; Moran and Wood, 2014). For this reason we do not provide an uncertainty estimate for these emissions, but based on model comparisons and sensitivity analysis, they are unlikely to be larger than for the territorial emission estimates (Peters et al., 2012a). Uncertainty is expected to increase for more detailed results, and to decrease with aggregation (Peters et al., 2011b; e.g. the results for Annex B countries will be more accurate than the sector results for an individual country).

The consumption-based emissions attribution method considers the $\mathrm{CO}_{2}$ emitted to the atmosphere in the production of products, but not the trade in fossil fuels (coal, oil, gas). It is also possible to account for the carbon trade in fossil fuels (Andrew et al., 2013), but we do not present those data here. Peters et al. (2012a) additionally considered trade in biomass.

The consumption data do not modify the global average terms in Eq. (1) but are relevant to the anthropogenic carbon cycle as they reflect the trade-driven movement of emissions across the Earth's surface in response to human activities. Furthermore, if national and international climate policies continue to develop in an un-harmonised way, then the trends reflected in these data will need to be accommodated by those developing policies. 


\subsubsection{Growth rate in emissions}

We report the annual growth rate in emissions for adjacent years (in percent per year) by calculating the difference between the two years and then comparing to the emissions in the first year: $\left[\frac{E_{\mathrm{FF}\left(t_{0+1}\right)}-E_{\mathrm{FF}\left(t_{0}\right)}}{E_{\mathrm{FF}\left(t_{0}\right)}}\right] \times 100 \% \mathrm{yr}^{-1}$. This is the simplest method to characterise a 1-year growth compared to the previous year and is widely used. We apply a leap-year adjustment to ensure valid interpretations of annual growth rates. This affects the growth rate by about $0.3 \% \mathrm{yr}^{-1}$ $(1 / 365)$ and causes growth rates to go up approximately $0.3 \%$ if the first year is a leap year and down $0.3 \%$ if the second year is a leap year.

The relative growth rate of $E_{\mathrm{FF}}$ over time periods of greater than 1 year can be re-written using its logarithm equivalent as follows:

$$
\frac{1}{E_{\mathrm{FF}}} \frac{\mathrm{d} E_{\mathrm{FF}}}{\mathrm{d} t}=\frac{\mathrm{d}\left(\ln E_{\mathrm{FF}}\right)}{\mathrm{d} t} .
$$

Here we calculate relative growth rates in emissions for multi-year periods (e.g. a decade) by fitting a linear trend to $\ln \left(E_{\mathrm{FF}}\right)$ in Eq. (2), reported in percent per year. We fit the logarithm of $E_{\mathrm{FF}}$ rather than $E_{\mathrm{FF}}$ directly because this method ensures that computed growth rates satisfy Eq. (6). This method differs from previous papers (Canadell et al., 2007; Le Quéré et al., 2009; Raupach et al., 2007) that computed the fit to $E_{\mathrm{FF}}$ and divided by average $E_{\mathrm{FF}}$ directly, but the difference is very small $\left(<0.05 \% \mathrm{yr}^{-1}\right)$ in the case of $E_{\mathrm{FF}}$.

\subsubsection{Emissions projections}

Energy statistics from BP are normally available around June for the previous year. To gain insight on emission trends for the current year (2016), we provide an assessment of global emissions for $E_{\mathrm{FF}}$ by combining individual assessments of emissions for China and the USA (the two biggest emitting countries) and the rest of the world.

We specifically estimate emissions in China because the data indicate a significant departure from the long-term trends in the carbon intensity of the economy used in emissions projections in previous global carbon budgets (e.g. Le Quéré et al., 2015a), resulting from a rapid deceleration in emissions growth against continued growth in economic output. This departure could be temporary (Jackson et al., 2016). Our 2016 estimate for China uses (1) coal consumption estimates from the China Coal Industry Association for January through September (CCIA, 2016), (2) estimated consumption of natural gas (IEW, 2016; NDRC, 2016a) and domestic production plus net imports of petroleum (NDRC, 2016b) for January through July from the National Development and Reform Commission, and (3) production of cement reported for January to September (NBS, 2016). Using these data, we estimate the change in emissions for the corresponding months in 2016 compared to 2015 assuming a $2 \%$ increase in the energy (and thus carbon) content of coal for 2016 resulting from improvements in the quality of the coal used, in line with the trends reported by the National Bureau of Statistics for recent years. We then assume that the relative changes during the first months will persist throughout the year. The main sources of uncertainty are from the incomplete data on stock changes, the carbon content of coal, and the assumption of persistent behaviour for the rest of the year. These are discussed further in Sect. 3.2.1.

For the USA, we use the forecast of the US Energy Information Administration (EIA) for emissions from fossil fuels (EIA, 2016). This is based on an energy forecasting model which is revised monthly, and takes into account heating degree days, household expenditures by fuel type, energy markets, policies, and other effects. We combine this with our estimate of emissions from cement production using the monthly US cement data from USGS for January-July, assuming changes in cement production over the first seven months apply throughout the year. While the EIA's forecasts for current full-year emissions have on average been revised downwards, only seven such forecasts are available, so we conservatively use the full range of adjustments following revision, and additionally assume symmetrical uncertainty to give $\pm 2.3 \%$ around the central forecast.

For the rest of the world, we use the close relationship between the growth in GDP and the growth in emissions (Raupach et al., 2007) to project emissions for the current year. This is based on the so-called Kaya identity (also called IPAT identity, the acronym standing for human impact $(I)$ on the environment, which is equal to the product of population $(P)$, affluence $(A)$, and technology $(T)$ ), whereby $E_{\mathrm{FF}}\left(\mathrm{GtC} \mathrm{yr}^{-1}\right)$ is decomposed by the product of GDP (USD $\mathrm{yr}^{-1}$ ) and the fossil fuel carbon intensity of the economy $\left(I_{\mathrm{FF}} ; \mathrm{GtC} \mathrm{USD}^{-1}\right)$ as follows:

$E_{\mathrm{FF}}=\mathrm{GDP} \times I_{\mathrm{FF}}$.

Such product-rule decomposition identities imply that the relative growth rates of the multiplied quantities are additive. Taking a time derivative of Eq. (3) gives

$\frac{\mathrm{d} E_{\mathrm{FF}}}{\mathrm{d} t}=\frac{\mathrm{d}\left(\mathrm{GDP} \times I_{\mathrm{FF}}\right)}{\mathrm{d} t}$

and, applying the rules of calculus,

$\frac{\mathrm{d} E_{\mathrm{FF}}}{\mathrm{d} t}=\frac{\mathrm{dGDP}}{\mathrm{d} t} \times I_{\mathrm{FF}}+\mathrm{GDP} \times \frac{\mathrm{d} I_{\mathrm{FF}}}{\mathrm{d} t}$.

Finally, dividing Eq. (5) by Eq. (3) gives

$\frac{1}{E_{\mathrm{FF}}} \frac{\mathrm{d} E_{\mathrm{FF}}}{\mathrm{d} t}=\frac{1}{\mathrm{GDP}} \frac{\mathrm{dGDP}}{\mathrm{d} t}+\frac{1}{I_{\mathrm{FF}}} \frac{\mathrm{d} I_{\mathrm{FF}}}{\mathrm{d} t}$,

where the left-hand term is the relative growth rate of $E_{\mathrm{FF}}$, and the right-hand terms are the relative growth rates of GDP 
and $I_{\mathrm{FF}}$, respectively, which can simply be added linearly to give overall growth rate. The growth rates are reported in percent by multiplying each term by 100 . As preliminary estimates of annual change in GDP are made well before the end of a calendar year, making assumptions on the growth rate of $I_{\mathrm{FF}}$ allows us to make projections of the annual change in $\mathrm{CO}_{2}$ emissions well before the end of a calendar year. The $I_{\mathrm{FF}}$ is based on GDP in constant PPP (purchasing power parity) from the IEA up to 2013 (IEA/OECD, 2015) and extended using the IMF growth rates for 2014 and 2015 (IMF, 2016). Interannual variability in $I_{\mathrm{FF}}$ is the largest source of uncertainty in the GDP-based emissions projections. We thus use the standard deviation of the annual $I_{\mathrm{FF}}$ for the period 2006-2015 as a measure of uncertainty, reflecting a $\pm 1 \sigma$ as in the rest of the carbon budget. This is $\pm 1.0 \% \mathrm{yr}^{-1}$ for the rest of the world (global emissions minus China and USA).

The 2016 projection for the world is made of the sum of the projections for China, USA, and the rest of the world. The uncertainty is added in quadrature among the three regions. The uncertainty here reflects the best of our expert opinion.

\section{2 $\mathrm{CO}_{2}$ emissions from land use, land-use change, and forestry ( $\left.E_{\text {LUC }}\right)$}

Land-use-change emissions reported here $\left(E_{\mathrm{LUC}}\right)$ include $\mathrm{CO}_{2}$ fluxes from deforestation, afforestation, logging (forest degradation and harvest activity), shifting cultivation (cycle of cutting forest for agriculture and then abandoning), and regrowth of forests following wood harvest or abandonment of agriculture. Only some land management activities are included in our land-use-change emissions estimates (Table 5). Some of these activities lead to emissions of $\mathrm{CO}_{2}$ to the atmosphere, while others lead to $\mathrm{CO}_{2}$ sinks. $E_{\mathrm{LUC}}$ is the net sum of all anthropogenic activities considered. Our annual estimate for 1959-2010 is from a bookkeeping method (Sect. 2.2.1) primarily based on net forest area change and biomass data from the Forest Resource Assessment (FRA) of the Food and Agriculture Organization (FAO), which are only available at intervals of 5 years. We use the bookkeeping method based on FAO FRA 2010 here (Houghton et al., 2012) and present preliminary results of an update using the FAO FRA 2015 (Houghton and Nassikas, 2016). Interannual variability in emissions due to deforestation and degradation have been coarsely estimated from satellite-based fire activity in tropical forest areas (Sect. 2.2.2; Giglio et al., 2013; van der Werf et al., 2010). The bookkeeping method is used to quantify the $E_{\mathrm{LUC}}$ over the time period of the available data, and the satellite-based deforestation fire information to incorporate interannual variability ( $E_{\mathrm{LUC}}$ flux annual anomalies) from tropical deforestation fires. The satellite-based deforestation and degradation fire emissions estimates are available for years 1997-2015. We calculate the global annual anomaly in deforestation and degradation fire emissions in tropical forest regions for each year, compared to the 19972010 period, and add this annual flux anomaly to the $E_{\text {LUC }}$ estimated using the published bookkeeping method that is available up to 2010 only and assumed constant at the 2010 value during the period 2011-2015. We thus assume that all land management activities apart from deforestation and degradation do not vary significantly on a year-to-year basis. Other sources of interannual variability (e.g. the impact of climate variability on regrowth fluxes) are accounted for in $S_{\text {LAND. }}$ In addition, we use results from dynamic global vegetation models (see Sect. 2.2.3 and Table 6) that calculate net land-use-change $\mathrm{CO}_{2}$ emissions in response to landcover change reconstructions prescribed to each model in order to help quantify the uncertainty in $E_{\mathrm{LUC}}$ and to explore the consistency of our understanding. The three methods are described below, and differences are discussed in Sect. 3.2. A discussion of other methods to estimate $E_{\mathrm{LUC}}$ was provided in the 2015 update (Le Quéré et al., 2015a; Sect. 2.2.4).

\subsubsection{Bookkeeping method}

Land-use-change $\mathrm{CO}_{2}$ emissions are calculated by a bookkeeping method approach (Houghton, 2003) that keeps track of the carbon stored in vegetation and soils before deforestation or other land-use change, and the changes in forest age classes, or cohorts, of disturbed lands after land-use change, including possible forest regrowth after deforestation. The method tracks the $\mathrm{CO}_{2}$ emitted to the atmosphere immediately during deforestation, and over time due to the followup decay of soil and vegetation carbon in different pools, including wood products pools after logging and deforestation. It also tracks the regrowth of vegetation and associated build-up of soil carbon pools after land-use change. It considers transitions between forests, pastures, and cropland; shifting cultivation; degradation of forests where a fraction of the trees is removed; abandonment of agricultural land; and forest management such as wood harvest and, in the USA, fire management. In addition to tracking logging debris on the forest floor, the bookkeeping method tracks the fate of carbon contained in harvested wood products that is eventually emitted back to the atmosphere as $\mathrm{CO}_{2}$, although a detailed treatment of the lifetime in each product pool is not performed (Earles et al., 2012). Harvested wood products are partitioned into three pools with different turnover times. All fuel wood is assumed burned in the year of harvest $\left(1.0 \mathrm{yr}^{-1}\right)$. Pulp and paper products are oxidised at a rate of $0.1 \mathrm{yr}^{-1}$, timber is assumed to be oxidised at a rate of $0.01 \mathrm{yr}^{-1}$, and elemental carbon decays at $0.001 \mathrm{yr}^{-1}$. The general assumptions about partitioning wood products among these pools are based on national harvest data (Houghton, 2003).

The primary land-cover change and biomass data for the bookkeeping method analysis is the Forest Resource Assessment of the FAO which provides statistics on forest-cover change and management at intervals of 5 years (FAO, 2010). The data are based on countries' self-reporting, some of which include satellite data in more recent assessments (Table 4). Changes in land cover other than forest are based 
Table 5. Comparison of the processes included in the bookkeeping method and DGVMs in their estimates of $E_{\text {LUC }}$ and $S_{\text {LAND }}$ See Table 6 for model references. All models include deforestation and forest regrowth after abandonment of agriculture (or from afforestation activities on agricultural land). Processes relevant for $E_{\mathrm{LUC}}$ are only described for the DGVMs used with land-cover change in this study (Fig. 6 top panel).

\begin{tabular}{|c|c|c|c|c|c|c|c|c|c|c|c|c|c|c|c|}
\hline & 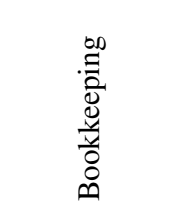 & 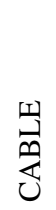 & 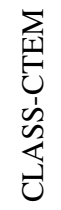 & $\sum_{\circlearrowright}$ & 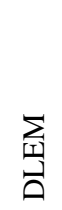 & $\sum_{\overparen{Z}}$ & 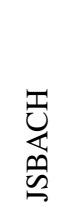 & 至 & 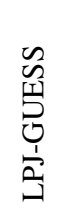 & $\vec{a}$ & $\begin{array}{l}E \\
0 \\
\infty \\
\dot{x} \\
a \\
a\end{array}$ & Z & 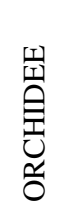 & 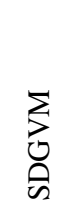 & $\stackrel{\bullet}{\bar{\Omega}}$ \\
\hline \multicolumn{16}{|c|}{ Processes relevant for $E_{\mathrm{LUC}}$} \\
\hline $\begin{array}{l}\text { Wood harvest and for- } \\
\text { est degradation }{ }^{\mathrm{a}}\end{array}$ & yes & & & & & yes & & no & no & no & & yes & & & \\
\hline Shifting cultivation & yes $^{\mathrm{b}}$ & & & & & no & & no & no & no & & no & & & \\
\hline Cropland harvest & yes & & & & & yes & & no & yes & no & & yes & & & \\
\hline Peat fires & no & & & & & no & & no & no & no & & no & & & \\
\hline \multicolumn{16}{|c|}{ Processes also relevant for $S_{\mathrm{LAND}}$} \\
\hline $\begin{array}{l}\text { Fire simulation and/or } \\
\text { suppression }\end{array}$ & for US only & no & yes & yes & yes & no & yes & no & yes & yes & yes & no & no & yes & yes \\
\hline Climate and variability & no & yes & yes & yes & yes & yes & yes & yes & yes & yes & yes & yes & yes & yes & yes \\
\hline $\mathrm{CO}_{2}$ fertilisation & no & yes & yes & yes & yes & yes & yes & yes & yes & yes & yes & yes & yes & yes & yes \\
\hline $\begin{array}{l}\text { Carbon-nitrogen inter- } \\
\text { actions, including } \mathrm{N} \mathrm{de-} \\
\text { position }\end{array}$ & no & yes & no & yes & yes & yes & no & no & yes & no & yes & yes & no & $\mathrm{yes}^{\mathrm{c}}$ & no \\
\hline
\end{tabular}

${ }^{a}$ Refers to the routine harvest of established managed forests rather than pools of harvested products. ${ }^{b}$ Not in the recent update (Houghton and Nassikas, 2016). ${ }^{\mathrm{c}}$ Very limited. Nitrogen uptake is simulated as a function of soil C, and Vcmax is an empirical function of canopy N. Does not consider N deposition.

on annual, national changes in cropland and pasture areas reported by the FAO Statistics Division (FAOSTAT, 2010). Land-use-change country data are aggregated by regions. The carbon stocks on land (biomass and soils), and their response functions subsequent to land-use change, are based on FAO data averages per land-cover type, per biome, and per region. Similar results were obtained using forest biomass carbon density based on satellite data (Baccini et al., 2012). The bookkeeping method does not include land ecosystems' transient response to changes in climate, atmospheric $\mathrm{CO}_{2}$, and other environmental factors, and the growth/decay curves are based on contemporary data that will implicitly reflect the effects of $\mathrm{CO}_{2}$ and climate at that time. Published results from the bookkeeping method are available from 1850 to 2010 , with preliminary results available to 2015 .

\subsubsection{Fire-based interannual variability in $E_{\text {LUC }}$}

$\mathrm{CO}_{2}$ emissions associated with land-use change calculated from satellite-based fire activity in tropical forest areas (van der Werf et al., 2010) provide information on emissions due to tropical deforestation and degradation that are complementary to the bookkeeping approach. They do not provide a direct estimate of $E_{\mathrm{LUC}}$ as they do not include noncombustion processes such as respiration, wood harvest, wood products, or forest regrowth. Legacy emissions such as decomposition from on-ground debris and soils are not included in this method either. However, fire estimates provide some insight in the year-to-year variations in the subcomponent of the total $E_{\mathrm{LUC}}$ flux that result from immediate $\mathrm{CO}_{2}$ emissions during deforestation caused, for example, by the interactions between climate and human activity (e.g. there is more burning and clearing of forests in dry years) that are not represented by other methods. The "deforestation fire emissions" assume an important role of fire in removing biomass in the deforestation process and thus can be used to infer gross instantaneous $\mathrm{CO}_{2}$ emissions from deforestation using satellite-derived data on fire activity in regions with active deforestation. The method requires information on the fraction of total area burned associated with deforestation vs. other types of fires, and this information can be merged with information on biomass stocks and the fraction of the biomass lost in a deforestation fire to estimate $\mathrm{CO}_{2}$ emissions. The satellite-based deforestation fire emissions are limited to the tropics, where fires result mainly from human activities. Tropical deforestation is the largest and most variable single contributor to $E_{\mathrm{LUC}}$.

Fire emissions associated with deforestation and tropical peat burning are based on the Global Fire Emissions Database (GFED4; accessed July 2016) described in van der Werf et al. (2010) but with updated burned area (Giglio et al., 2013) as well as burned area from relatively small 
Table 6. References for the process models and data products included in Figs. 6-8. All models and products are updated with new data to end of year 2015 .

\begin{tabular}{|c|c|c|}
\hline Model/data name & Reference & Change from Le Quéré et al. (2015a) \\
\hline \multicolumn{3}{|c|}{ Dynamic global vegetation models } \\
\hline CABLE & Zhang et al. (2013) & Not applicable (not used in 2015) \\
\hline CLASS-CTEM & Melton and Arora (2016) & Not applicable (not used in 2015) \\
\hline CLM & Oleson et al. (2013) & No change \\
\hline DLEM & Tian et al. (2010) & Not applicable (not used in 2015) \\
\hline ISAM & Jain et al. (2013) & $\begin{array}{l}\text { Updated to account for dynamic phenology and dynamic rooting distribution and depth param- } \\
\text { eterisations for various ecosystem types as described in El Masri et al. (2015). These parame- } \\
\text { terisations account for light, water, and nutrient stresses while allocating the assimilated carbon } \\
\text { to leaf, stem, and root pools. }\end{array}$ \\
\hline JSBACH & Reick et al. $(2013)^{\mathrm{a}}$ & No change \\
\hline $\mathrm{JULES}^{\mathrm{b}}$ & Clark et al. $(2011)^{\mathrm{c}}$ & $\begin{array}{l}\text { Updated to code release } 4.6 \text { and configuration JULES-C-1.1. This version includes improve- } \\
\text { ments to the seasonal cycle of soil respiration. }\end{array}$ \\
\hline LPJ-GUESS & Smith et al. (2014) & $\begin{array}{l}\text { Use of CRU-NCEP. Crop representation in LPJ-GUESS was adopted from Olin et al. (2015), } \\
\text { applying constant fertiliser rate and area fraction under irrigation, as in Elliott et al. (2015). }\end{array}$ \\
\hline LPJ $^{\mathrm{d}}$ & Sitch et al. $(2003)^{\mathrm{e}}$ & No change \\
\hline LPX-Bern & Stocker et al. $(2014)^{\mathrm{f}}$ & Not applicable (not used in 2015) \\
\hline $\mathrm{OCN}$ & $\begin{array}{l}\text { Zaehle and Friend } \\
(2010)^{\mathrm{g}}\end{array}$ & $\begin{array}{l}\text { Updated to v1.r278. Biological N fixation is now simulated dynamically according to the OPT } \\
\text { scheme of Meyerholt et al. (2016). }\end{array}$ \\
\hline ORCHIDEE & Krinner et al. $(2005)^{\mathrm{h}}$ & $\begin{array}{l}\text { Updated revision } 3687 \text {, including a new hydrological scheme with } 11 \text { layers and a complete } \\
\text { diffusion scheme, a new parameterisation of photosynthesis, an improved scheme for represen- } \\
\text { tation of snow, and a new representation of soil albedo based on satellite data. }\end{array}$ \\
\hline SDGVM & Woodward et al. $(1995)^{\mathrm{i}}$ & Not applicable (not used in 2015) \\
\hline VISIT & Kato et al. $(2013)^{\mathrm{j}}$ & $\begin{array}{l}\text { Updated to use CRU-NCEP shortwave radiation data instead of using internally estimated radi- } \\
\text { ation from CRU cloudiness data. }\end{array}$ \\
\hline \multicolumn{3}{|c|}{ Data products for land-use-change emissions } \\
\hline Bookkeeping & Houghton et al. (2012) & No change \\
\hline $\begin{array}{l}\text { Bookkeeping using } \\
\text { FAO2015 }\end{array}$ & $\begin{array}{l}\text { Houghton and Nassikas } \\
(2016)\end{array}$ & Not applicable (not used in 2015) \\
\hline Fire-based emissions & van der Werf et al. (2010) & No change \\
\hline
\end{tabular}

Ocean biogeochemistry models

$\begin{array}{lll}\text { NEMO-PlankTOM5 } & \text { Buitenhuis et al. (2010) } & \text { No change } \\ \text { NEMO-PISCES (IPSL) } & \text { Aumont and Bopp (2006) } & \text { No change } \\ \begin{array}{l}\text { CCSM-BEC } \\ \text { MICOM-HAMOCC } \\ \text { (NorESM-OC) }\end{array} & \begin{array}{l}\text { Doney et al. (2009) } \\ \text { Schwinger et al. (2016) }\end{array} & \begin{array}{l}\text { No change } \\ \text { No change }\end{array} \\ \begin{array}{ll}\text { NEMO-PISCES } \\ \text { CNRM) }\end{array} & \text { Séférian et al. (2013) } & \text { No change } \\ \begin{array}{l}\text { CSIRO } \\ \text { MITgcm-REcoM2 }\end{array} & \text { Oke et al. (2013) } & \text { No change } \\ \end{array}$

Data products for ocean $\mathrm{CO}_{2}$ flux

$\begin{array}{lll}\text { Landschützer } & \text { Landschützer et al. (2015) } & \begin{array}{l}\text { No change } \\ \text { Jena CarboScope }\end{array} \\ \text { Rödenbeck et al. (2014) } & \begin{array}{l}\text { Updated to version oc_1.4 with longer spin-up/down periods both before and after the data- } \\ \text { constrained period. }\end{array}\end{array}$

Atmospheric inversions for total $\mathrm{CO}_{2}$ fluxes (land-use-change + land + ocean $\mathrm{CO}_{2}$ fluxes)

\begin{tabular}{|c|c|c|}
\hline CarbonTracker & Peters et al. (2010) & Updated to version CTE2016-FT with minor changes in the inversion setup. \\
\hline Jena CarboScope & Rödenbeck et al. (2003) & Updated to version s81_v3.8. \\
\hline $\mathrm{CAMS}^{\mathrm{m}}$ & Chevallier et al. (2005) & Updated to version 15.2 with minor changes in the inversion setup. \\
\hline
\end{tabular}


fires that are detected by satellite as thermal anomalies but not mapped by the burned-area approach (Randerson et al., 2012). The burned-area information is used as input data in a modified version of the satellite-driven Carnegie-AmesStanford Approach (CASA) biogeochemical model to estimate carbon emissions associated with fires, keeping track of what fraction of fire emissions was due to deforestation (see van der Werf et al., 2010). The CASA model uses different assumptions to compute decay functions compared to the bookkeeping method, and does not include historical emissions or regrowth from land-use change prior to the availability of satellite data. Comparing coincident $\mathrm{CO}$ emissions and their atmospheric fate with satellite-derived $\mathrm{CO}$ concentrations allows for some validation of this approach (e.g. van der Werf et al., 2008). Results from the fire-based method to estimate land-use-change emissions anomalies added to the bookkeeping mean $E_{\mathrm{LUC}}$ estimate are available from 1997 to 2015. Our combination of land-use-change $\mathrm{CO}_{2}$ emissions where the variability in annual $\mathrm{CO}_{2}$ deforestation emissions is diagnosed from fires assumes that year-to-year variability is dominated by variability in deforestation.

\subsubsection{Dynamic global vegetation models (DGVMs)}

Land-use-change $\mathrm{CO}_{2}$ emissions have been estimated using an ensemble of DGVM simulations. New model experiments up to year 2015 have been coordinated by the project "Trends and drivers of the regional-scale sources and sinks of carbon dioxide" (TRENDY; Sitch et al., 2015). We use only models that have estimated land-use-change $\mathrm{CO}_{2}$ emissions following the TRENDY protocol (see Sect. 2.5.2). Models use their latest configurations, summarised in Tables 5 and 6.

Two sets of simulations were performed with the DGVMs, first forced with historical changes in land-cover distribution, climate, atmospheric $\mathrm{CO}_{2}$ concentration, and $\mathrm{N}$ deposition, and second, as further described below with a time-invariant pre-industrial land-cover distribution, allowing for estimation of, by difference with the first simulation, the dynamic evolution of biomass and soil carbon pools in response to prescribed land-cover change. Because of the limited availability of the land-use forcing (see below), 14 DGVMs performed historical simulations with time-invariant land-cover distribution, but only 5 DGVMs managed to simulate realistic simulations with time varying land-cover change. These latter DGVMs accounted for deforestation and (to some extent) regrowth, the most important components of $E_{\mathrm{LUC}}$, but they do not represent all processes resulting directly from human activities on land (Table 5). All DGVMs represent processes of vegetation growth and mortality, as well as decomposition of dead organic matter associated with natural cycles, and include the vegetation and soil carbon response to increasing atmospheric $\mathrm{CO}_{2}$ levels and to climate variability and change. In addition, eight models explicitly simulate the coupling of $\mathrm{C}$ and $\mathrm{N}$ cycles and account for atmospheric $\mathrm{N}$ deposition (Table 5), with three of those models used for land-use-change simulations. The DGVMs are independent of the other budget terms except for their use of atmospheric $\mathrm{CO}_{2}$ concentration to calculate the fertilisation effect of $\mathrm{CO}_{2}$ on primary production.

For this global carbon budget, the DGVMs used the HYDE land-use-change data set (Klein Goldewijk et al., 2011), which provides annual, half-degree, fractional data on cropland and pasture. These data are based on annual FAO statistics of change in agricultural area available to 2012 (FAOSTAT, 2010). For the years 2013 to 2015, the HYDE data were extrapolated by country for pastures and cropland separately based on the trend in agricultural area over the previous 5 years. The more comprehensive harmonised land-use data set (Hurtt et al., 2011), which also includes fractional data on primary vegetation and secondary vegetation, as well as all underlying transitions between land-use states, has not been made available yet for this year. Hence, the reduced ensemble of DGVMs that can simulate the LUC flux from the HYDE data set only. The HYDE data are independent of the data set used in the bookkeeping method (Houghton, 2003, and updates), which is based primarily on forest area change statistics (FAO, 2010). The HYDE land-use-change data set does not indicate whether land-use changes occur on forested or non-forested land; it only provides the changes in agricultural areas. Hence, it is implemented differently within each model (e.g. an increased cropland fraction in a grid cell can be at the expense of either grassland or forest, the latter resulting in deforestation; land-cover fractions of the nonagricultural land differ between models). Thus, the DGVM forest area and forest area change over time is not consistent with the Forest Resource Assessment of the FAO forest area data used for the bookkeeping model to calculate $E_{\mathrm{LUC}}$. Similarly, model-specific assumptions are applied to convert deforested biomass or deforested area, and other forest product pools, into carbon in some models (Table 5).

The DGVM runs were forced by either 6-hourly CRUNCEP or by monthly CRU temperature, precipitation, and cloud cover fields (transformed into incoming surface radiation) based on observations and provided on a $0.5^{\circ} \times 0.5^{\circ}$ grid and updated to 2015 (Harris et al., 2014; Viovy, 2016). The forcing data include both gridded observations of climate and global atmospheric $\mathrm{CO}_{2}$, which change over time (Dlugokencky and Tans, 2016), and $\mathrm{N}$ deposition (as used in some models; Table 5). As mentioned before, $E_{\mathrm{LUC}}$ is diagnosed in each model by the difference between a model simulation with prescribed historical land-cover change and a simulation with constant, pre-industrial land-cover distribution. Both simulations were driven by changing atmospheric $\mathrm{CO}_{2}$, climate, and, in some models, $\mathrm{N}$ deposition over the period 1860-2015. Using the difference between these two DGVM simulations to diagnose $E_{\mathrm{LUC}}$ is not fully consistent with the definition of $E_{\mathrm{LUC}}$ in the bookkeeping method (Gasser and Ciais, 2013; Stocker and Joos, 2015). The DGVM approach to diagnose land-use-change $\mathrm{CO}_{2}$ emissions would be expected to produce systematically higher 
Table 7. Comparison of results from the bookkeeping method and budget residuals with results from the DGVMs and inverse estimates for the periods 1960-1969, 1970-1979, 1980-1989, 1990-1999, and 2000-2009, as well as the last decade and last year available. All values

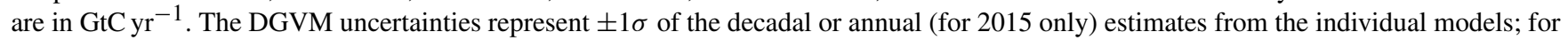
the inverse models all three results are given where available.

\begin{tabular}{|c|c|c|c|c|c|c|c|}
\hline & \multicolumn{7}{|c|}{ Mean $\left(\mathrm{GtC} \mathrm{yr}^{-1}\right)$} \\
\hline & $1960-1969$ & 1970-1979 & $1980-1989$ & 1990-1999 & $2000-2009$ & $2006-2015$ & 2015 \\
\hline \multicolumn{8}{|l|}{ Land-use-change emissions ( $\left.E_{\mathrm{LUC}}\right)$} \\
\hline Bookkeeping method & $1.5 \pm 0.5$ & $1.3 \pm 0.5$ & $1.4 \pm 0.5$ & $1.6 \pm 0.5$ & $1.0 \pm 0.5$ & $1.0 \pm 0.5$ & $1.3 \pm 0.5$ \\
\hline $\operatorname{DGVMs}^{\mathrm{a}}$ & $1.2 \pm 0.3$ & $1.2 \pm 0.3$ & $1.2 \pm 0.2$ & $1.2 \pm 0.2$ & $1.1 \pm 0.2$ & $1.3 \pm 0.3$ & $1.2 \pm 0.4$ \\
\hline \multicolumn{8}{|l|}{ Residual terrestrial sink ( $\left.S_{\text {LAND }}\right)$} \\
\hline Budget residual & $1.7 \pm 0.7$ & $1.7 \pm 0.8$ & $1.6 \pm 0.8$ & $2.6 \pm 0.8$ & $2.6 \pm 0.8$ & $3.1 \pm 0.9$ & $1.9 \pm 0.9$ \\
\hline $\mathrm{DGVMs}^{\mathrm{a}}$ & $1.2 \pm 0.5$ & $2.2 \pm 0.5$ & $1.7 \pm 0.6$ & $2.3 \pm 0.5$ & $2.8 \pm 0.6$ & $2.8 \pm 0.7$ & $1.0 \pm 1.4$ \\
\hline \multicolumn{8}{|l|}{ Total land fluxes ( $\left.S_{\text {LAND }}-E_{\text {LUC }}\right)$} \\
\hline Budget $\left(E_{\mathrm{FF}}-G_{\mathrm{ATM}}-S_{\mathrm{OCEAN}}\right)$ & $0.2 \pm 0.5$ & $0.4 \pm 0.6$ & $0.1 \pm 0.6$ & $1.0 \pm 0.6$ & $1.6 \pm 0.6$ & $2.2 \pm 0.7$ & $0.6 \pm 0.7$ \\
\hline$D_{\text {DVMs }}{ }^{\mathrm{a}}$ & $-0.2 \pm 0.7$ & $1.1 \pm 0.5$ & $0.4 \pm 0.5$ & $1.1 \pm 0.3$ & $1.8 \pm 0.4$ & $1.7 \pm 0.5$ & $-0.1 \pm 1.4$ \\
\hline $\begin{array}{l}\text { Inversions (CTE2016-FT/Jena } \\
\text { CarboScope/CAMS) }\end{array}$ & $-1-1-$ & $-1-1-$ & $-/ 0.2^{\mathrm{b}} / 0.9^{\mathrm{b}}$ & $-11.0^{\mathrm{b}} / 1.9^{\mathrm{b}}$ & $1.5^{\mathrm{b}} / 1.6^{\mathrm{b}} / 2.5^{\mathrm{b}}$ & $2.2^{\mathrm{b}} / 2.3^{\mathrm{b}} / 3.4^{\mathrm{b}}$ & $1.9^{\mathrm{b}} / 2.6^{\mathrm{b}} / 2.6^{\mathrm{b}}$ \\
\hline
\end{tabular}

${ }^{a}$ Note that for DGVMs, the mean reported for the total land fluxes is not equal to the difference between the means reported for $S_{\mathrm{LAND}}$ and $E_{\mathrm{LUC}}$ as a different set of models contributed to these two estimates (see Sect. 2.2.3). ${ }^{\mathrm{b}}$ Estimates are not corrected for the influence of river fluxes, which would reduce the fluxes by $0.45 \mathrm{GtC}^{-1} \mathrm{when}^{-1}$ neglecting the anthropogenic influence on land (Sect. 2.7.2). See Table 6 for model references.

$E_{\mathrm{LUC}}$ emissions than the bookkeeping approach if all the parameters of the two approaches were the same, which is not the case (see Sect. 2.5.2).

\subsubsection{Uncertainty assessment for $E_{\text {LUC }}$}

Differences between the bookkeeping, the addition of firebased interannual variability to the bookkeeping, and DGVM methods originate from three main sources: the land-coverchange data set, the different approaches used in models, and the different processes represented (Table 5). We examine the results from the DGVMs and of the bookkeeping method to assess the uncertainty in $E_{\mathrm{LUC}}$.

The uncertainties in annual $E_{\mathrm{LUC}}$ estimates are examined using the standard deviation across models, which averages $0.3 \mathrm{GtC} \mathrm{yr}^{-1}$ from 1959 to 2015 (Table 7). The mean of the multi-model $E_{\mathrm{LUC}}$ estimates is consistent with a combination of the bookkeeping method and fire-based emissions (Table 7), with the multi-model mean and bookkeeping method differing by less than $0.5 \mathrm{GtC} \mathrm{yr}^{-1}$ over $85 \%$ of the time. Based on this comparison, we determine that an uncertainty of $\pm 0.5 \mathrm{GtC} \mathrm{yr}^{-1}$ provides a semi-quantitative measure of uncertainty for annual emissions and reflects our best value judgement that there is at least $68 \%$ chance $( \pm 1 \sigma)$ that the true land-use-change emission lies within the given range, for the range of processes considered here. This is consistent with the uncertainty analysis of Houghton et al. (2012), which partly reflects improvements in data on forest area change using data and partly more complete understanding and representation of processes in models.

The uncertainties in the decadal $E_{\mathrm{LUC}}$ estimates are also examined using the DGVM ensemble, although they are likely correlated between decades. The correlations between decades come from (1) common biases in system boundaries (e.g. not counting forest degradation in some models), (2) common definition for the calculation of $E_{\mathrm{LUC}}$ from the difference of simulations with and without land-use change (a source of bias vs. the unknown truth), (3) common and uncertain land-cover change input data which also cause a bias (though if a different input data set is used each decade, decadal fluxes from DGVMs may be partly decorrelated), and (4) model structural errors (e.g. systematic errors in biomass stocks). In addition, errors arising from uncertain DGVM parameter values would be random but they are not accounted for in this study, since no DGVM provided an ensemble of runs with perturbed parameters.

Prior to 1959 , the uncertainty in $E_{\mathrm{LUC}}$ is taken as $\pm 33 \%$, which is the ratio of uncertainty to mean from the 1960s in the bookkeeping method (Table 7), the first decade available. This ratio is consistent with the mean standard deviation of DGVMs land-use-change emissions over 1870-1958 $(0.32 \mathrm{GtC})$ over the multi-model mean $(0.9 \mathrm{GtC})$.

\subsection{Growth rate in atmospheric $\mathrm{CO}_{2}$ concentration $\left(G_{\text {ATM }}\right)$}

\section{Global growth rate in atmospheric $\mathrm{CO}_{2}$ concentration}

The rate of growth of the atmospheric $\mathrm{CO}_{2}$ concentration is provided by the US National Oceanic and Atmospheric Administration Earth System Research Laboratory (NOAA/ESRL; Dlugokencky and Tans, 2016), which is updated from Ballantyne et al. (2012). For the 1959-1980 period, the global growth rate is based on measurements of 
atmospheric $\mathrm{CO}_{2}$ concentration averaged from the Mauna Loa and South Pole stations, as observed by the $\mathrm{CO}_{2}$ Program at Scripps Institution of Oceanography (Keeling et al., 1976). For the 1980-2015 time period, the global growth rate is based on the average of multiple stations selected from the marine boundary layer sites with well-mixed background air (Ballantyne et al., 2012), after fitting each station with a smoothed curve as a function of time, and averaging by latitude band (Masarie and Tans, 1995). The annual growth rate is estimated by Dlugokencky and Tans (2016) from atmospheric $\mathrm{CO}_{2}$ concentration by taking the average of the most recent December-January months corrected for the average seasonal cycle and subtracting this same average 1 year earlier. The growth rate in units of $\mathrm{ppm} \mathrm{yr}^{-1}$ is converted to units of $\mathrm{GtC} \mathrm{yr}^{-1}$ by multiplying by a factor of $2.12 \mathrm{GtC} \mathrm{ppm}^{-1}$ (Ballantyne et al., 2012) for consistency with the other components.

The uncertainty around the annual growth rate based on the multiple stations data set ranges between 0.11 and $0.72 \mathrm{GtC} \mathrm{yr}^{-1}$, with a mean of $0.61 \mathrm{GtC} \mathrm{yr}^{-1}$ for $1959-1979$ and $0.19 \mathrm{GtC} \mathrm{yr}^{-1}$ for $1980-2015$, when a larger set of stations were available (Dlugokencky and Tans, 2016). It is based on the number of available stations, and thus takes into account both the measurement errors and data gaps at each station. This uncertainty is larger than the uncertainty of $\pm 0.1 \mathrm{GtC} \mathrm{yr}^{-1}$ reported for decadal mean growth rate by the IPCC because errors in annual growth rate are strongly anti-correlated in consecutive years leading to smaller errors for longer timescales. The decadal change is computed from the difference in concentration 10 years apart based on a measurement error of $0.35 \mathrm{ppm}$. This error is based on offsets between NOAA/ESRL measurements and those of the World Meteorological Organization World Data Centre for Greenhouse Gases (NOAA/ESRL, 2015) for the start and end points (the decadal change uncertainty is the $\sqrt{\left(2(0.35 \mathrm{ppm})^{2}\right)}(10 \mathrm{yr})^{-1}$ assuming that each yearly measurement error is independent). This uncertainty is also used in Table 8.

The contribution of anthropogenic $\mathrm{CO}$ and $\mathrm{CH}_{4}$ is neglected from the global carbon budget (see Sect. 2.7.1). We assign a high confidence to the annual estimates of $G_{\text {ATM }}$ because they are based on direct measurements from multiple and consistent instruments and stations distributed around the world (Ballantyne et al., 2012).

In order to estimate the total carbon accumulated in the atmosphere since 1750 or 1870 , we use an atmospheric $\mathrm{CO}_{2}$ concentration of $277 \pm 3$ or $288 \pm 3$ ppm, respectively, based on a cubic spline fit to ice core data (Joos and Spahni, 2008). The uncertainty of $\pm 3 \mathrm{ppm}$ (converted to $\pm 1 \sigma$ ) is taken directly from the IPCC's assessment (Ciais et al., 2013). Typical uncertainties in the growth rate in atmospheric $\mathrm{CO}_{2}$ concentration from ice core data are $\pm 1-1.5 \mathrm{GtC}$ per decade as evaluated from the Law Dome data (Etheridge et al., 1996) for individual 20-year intervals over the period from 1870 to 1960 (Bruno and Joos, 1997).

\subsection{Ocean $\mathrm{CO}_{2}$ sink}

Estimates of the global ocean $\mathrm{CO}_{2}$ sink are based on a combination of a mean $\mathrm{CO}_{2}$ sink estimate for the 1990s from observations, as well as a trend and variability in the ocean $\mathrm{CO}_{2}$ sink for 1959-2015 from seven global ocean biogeochemistry models. We use two observation-based estimates of $S_{\text {OCEAN }}$ available for recent decades to provide a qualitative assessment of confidence in the reported results.

\subsubsection{Observation-based estimates}

A mean ocean $\mathrm{CO}_{2}$ sink of $2.2 \pm 0.4 \mathrm{GtC} \mathrm{yr}^{-1}$ for the $1990 \mathrm{~s}$ was estimated by the IPCC (Denman et al., 2007) based on indirect observations and their spread: ocean-land $\mathrm{CO}_{2}$ sink partitioning from observed atmospheric $\mathrm{O}_{2} / \mathrm{N}_{2}$ concentration trends (Manning and Keeling, 2006), an oceanic inversion method constrained by ocean biogeochemistry data (Mikaloff Fletcher et al., 2006), and a method based on penetration timescale for CFCs (McNeil et al., 2003). This is comparable with the sink of $2.0 \pm 0.5 \mathrm{GtC} \mathrm{yr}^{-1}$ estimated by Khatiwala et al. (2013) for the 1990s, and with the sink of 1.9 to $2.5 \mathrm{GtC} \mathrm{yr}^{-1}$ estimated from a range of methods for the period 1990-2009 (Wanninkhof et al., 2013), with uncertainties ranging from \pm 0.3 to $\pm 0.7 \mathrm{GtC} \mathrm{yr}^{-1}$. The most direct way for estimating the observation-based ocean sink is from the product of (sea-air $p \mathrm{CO}_{2}$ difference) $\times$ (gas transfer coefficient). Estimates based on sea-air $p \mathrm{CO}_{2}$ are fully consistent with indirect observations (Wanninkhof et al., 2013), but their uncertainty is larger mainly due to difficulty in capturing complex turbulent processes in the gas transfer coefficient (Sweeney et al., 2007) and because of uncertainties in the pre-industrial river outgas of $\mathrm{CO}_{2}$ (Jacobson et al., 2007).

The two observation-based estimates (Landschützer et al., 2015; Rödenbeck et al., 2014) used here compute the ocean $\mathrm{CO}_{2}$ sink and its variability using interpolated measurements of surface ocean fugacity of $\mathrm{CO}_{2}\left(p \mathrm{CO}_{2}\right.$ corrected for the non-ideal behaviour of the gas; Pfeil et al., 2013). The measurements were from the Surface Ocean $\mathrm{CO}_{2}$ Atlas version 4, which is an update of version 3 (Bakker et al., 2016) and contains data to 2015 (see data attribution Table 1a). In contrast to last year's global carbon budget, where preliminary data were used for the past year, data used here are fully quality-controlled following standard SOCAT procedures. The SOCAT v4 were mapped using a data-driven diagnostic method (Rödenbeck et al., 2013) and a combined self-organising map and feed-forward neural network (Landschützer et al., 2014). The global observation-based estimates were adjusted to remove a background (not part of the anthropogenic ocean flux) ocean source of $\mathrm{CO}_{2}$ to the atmosphere of $0.45 \mathrm{GtC} \mathrm{yr}^{-1}$ from river input to the ocean (Jacobson et al., 2007) in order to make them comparable to 
Table 8. Decadal mean in the five components of the anthropogenic $\mathrm{CO}_{2}$ budget for the periods 1960-1969, 1970-1979, 1980-1989, 1990-

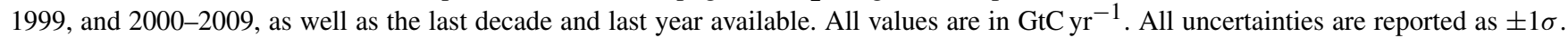
A data set containing data for each year during 1959-2014 is available at http://cdiac.ornl.gov/GCP/carbonbudget/2015/. Please follow the terms of use and cite the original data sources as specified in the data set.

\begin{tabular}{|c|c|c|c|c|c|c|c|}
\hline & \multicolumn{7}{|c|}{ Mean $\left(\mathrm{GtC} \mathrm{yr}^{-1}\right)$} \\
\hline & 1960-1969 & 1970-1979 & 1980-1989 & 1990-1999 & 2000-2009 & 2006-2015 & 2015 \\
\hline \multicolumn{8}{|l|}{ Emissions } \\
\hline $\begin{array}{l}\text { Fossil fuels and industry }\left(E_{\mathrm{FF}}\right) \\
\text { Land-use-change emissions } \\
\left(E_{\text {LUC }}\right)\end{array}$ & $\begin{array}{l}3.1 \pm 0.2 \\
1.5 \pm 0.5\end{array}$ & $\begin{array}{l}4.7 \pm 0.2 \\
1.3 \pm 0.5\end{array}$ & $\begin{array}{l}5.5 \pm 0.3 \\
1.4 \pm 0.5\end{array}$ & $\begin{array}{l}6.3 \pm 0.3 \\
1.6 \pm 0.5\end{array}$ & $\begin{array}{l}8.0 \pm 0.4 \\
1.0 \pm 0.5\end{array}$ & $\begin{array}{l}9.3 \pm 0.5 \\
1.0 \pm 0.5\end{array}$ & $\begin{array}{l}9.9 \pm 0.5 \\
1.3 \pm 0.5\end{array}$ \\
\hline \multicolumn{8}{|l|}{ Partitioning } \\
\hline $\begin{array}{l}\text { Growth rate in atmospheric } \\
\mathrm{CO}_{2} \text { concentration }\left(G_{\text {ATM }}\right)\end{array}$ & $1.7 \pm 0.1$ & $2.8 \pm 0.1$ & $3.4 \pm 0.1$ & $3.1 \pm 0.1$ & $4.0 \pm 0.1$ & $4.5 \pm 0.1$ & $6.3 \pm 0.2$ \\
\hline $\begin{array}{l}\text { Ocean sink }\left(S_{\text {OCEAN }}\right) \\
\text { Residual terrestrial sink } \\
\left(S_{\text {LAND }}\right)\end{array}$ & $\begin{array}{l}1.2 \pm 0.5 \\
1.7 \pm 0.7\end{array}$ & $\begin{array}{l}1.5 \pm 0.5 \\
1.7 \pm 0.8\end{array}$ & $\begin{array}{l}1.9 \pm 0.5 \\
1.6 \pm 0.8\end{array}$ & $\begin{array}{l}2.2 \pm 0.5 \\
2.6 \pm 0.8\end{array}$ & $\begin{array}{l}2.3 \pm 0.5 \\
2.6 \pm 0.8\end{array}$ & $\begin{array}{l}2.6 \pm 0.5 \\
3.1 \pm 0.9\end{array}$ & $\begin{array}{l}3.0 \pm 0.5 \\
1.9 \pm 0.9\end{array}$ \\
\hline
\end{tabular}

$S_{\text {OCEAN }}$, which only represents the annual uptake of anthropogenic $\mathrm{CO}_{2}$ by the ocean. Several other data-based products are available, but they show large discrepancies with observed variability that need to be resolved. Here we used the two data products that had the best fit to observations for their representation of tropical and global variability (Rödenbeck et al., 2015).

We use the data-based product of Khatiwala et al. (2009) updated by Khatiwala et al. (2013) to estimate the anthropogenic carbon accumulated in the ocean during 17651958 (60.2 GtC) and 1870-1958 (47.5 GtC), and assume an oceanic uptake of $0.4 \mathrm{GtC}$ for 1750-1765 (for which time no data are available) based on the mean uptake during 17651770. The estimate of Khatiwala et al. (2009) is based on regional disequilibrium between surface $p \mathrm{CO}_{2}$ and atmospheric $\mathrm{CO}_{2}$, and a Green's function utilising transient ocean tracers like $\mathrm{CFCs}$ and ${ }^{14} \mathrm{C}$ to ascribe changes through time. It does not include changes associated with changes in ocean circulation, temperature, and climate, but these are thought to be small over the time period considered here (Ciais et al., 2013). The uncertainty in cumulative uptake of $\pm 20 \mathrm{GtC}$ (converted to $\pm 1 \sigma$ ) is taken directly from the IPCC's review of the literature (Rhein et al., 2013), or about $\pm 30 \%$ for the annual values (Khatiwala et al., 2009).

\subsubsection{Global ocean biogeochemistry models}

The trend in the ocean $\mathrm{CO}_{2}$ sink for 1959-2015 is computed using a combination of seven global ocean biogeochemistry models (Table 6). The models represent the physical, chemi$\mathrm{cal}$, and biological processes that influence the surface ocean concentration of $\mathrm{CO}_{2}$ and thus the air-sea $\mathrm{CO}_{2}$ flux. The models are forced by meteorological reanalysis and atmospheric $\mathrm{CO}_{2}$ concentration data available for the entire time period. Models do not include the effects of anthropogenic changes in nutrient supply, which could lead to an increase in the ocean sink of up to about $0.3 \mathrm{GtC} \mathrm{yr}^{-1}$ over the industrial period (Duce et al., 2008). They compute the air-sea flux of $\mathrm{CO}_{2}$ over grid boxes of 1 to $4^{\circ}$ in latitude and longitude. The ocean $\mathrm{CO}_{2}$ sink for each model is normalised to the observations by dividing the annual model values by their modelled average over 1990-1999 and multiplying this by the observation-based estimate of $2.2 \mathrm{GtC} \mathrm{yr}^{-1}$ (obtained from Manning and Keeling, 2006; McNeil et al., 2003; Mikaloff Fletcher et al., 2006). The ocean $\mathrm{CO}_{2}$ sink for each year $(t)$ in $\mathrm{GtC} \mathrm{yr}^{-1}$ is therefore

$S_{\text {OCEAN }}(t)=\frac{1}{n} \sum_{m=1}^{m=n} \frac{S_{\text {OCEAN }}^{m}(t)}{S_{\text {OCEAN }}^{m}(1990-1999)} \times 2.2$,

where $n$ is the number of models. This normalisation ensures that the ocean $\mathrm{CO}_{2}$ sink for the global carbon budget is based on observations, whereas the trends and annual values in $\mathrm{CO}_{2}$ sinks are from model estimates. The normalisation based on a ratio assumes that if models over or underestimate the sink in the 1990s, it is primarily due to the process of diffusion, which depends on the gradient of $\mathrm{CO}_{2}$. Thus, a ratio is more appropriate than an offset as it takes into account the time dependence of $\mathrm{CO}_{2}$ gradients in the ocean. The mean uncorrected ocean $\mathrm{CO}_{2}$ sink from the models for 1990-1999 ranges between 1.7 and $2.4 \mathrm{GtC} \mathrm{yr}^{-1}$, with a multi-model mean of $2.0 \mathrm{GtC} \mathrm{yr}^{-1}$.

\subsubsection{Uncertainty assessment for $S_{\text {OCEAN }}$}

The uncertainty around the mean ocean sink of anthropogenic $\mathrm{CO}_{2}$ was quantified by Denman et al. (2007) for the 1990s (see Sect. 2.4.1). To quantify the uncertainty around 
annual values, we examine the standard deviation of the normalised model ensemble. We use further information from the two data-based products to assess the confidence level. The average standard deviation of the normalised ocean model ensemble is $0.16 \mathrm{GtC} \mathrm{yr}^{-1}$ during 1980-2010 (with a maximum of 0.33), but it increases as the model ensemble goes back in time, with a standard deviation of $0.22 \mathrm{GtC} \mathrm{yr}^{-1}$ across models in the 1960s. We estimate that the uncertainty in the annual ocean $\mathrm{CO}_{2}$ sink is about $\pm 0.5 \mathrm{GtC} \mathrm{yr}^{-1}$ from the fractional uncertainty in the data uncertainty of $\pm 0.4 \mathrm{GtC} \mathrm{yr}^{-1}$ and standard deviation across models of up to $\pm 0.33 \mathrm{GtC} \mathrm{yr}^{-1}$, reflecting both the uncertainty in the mean sink from observations during the 1990s (Denman et al., 2007; Sect. 2.4.1) and in the interannual variability as assessed by models.

We examine the consistency between the variability in the model-based and the data-based products to assess confidence in $S_{\text {OCEAN }}$. The interannual variability of the ocean fluxes (quantified as the standard deviation) of the two data-based estimates for 1986-2015 (where they overlap) is $\pm 0.34 \mathrm{GtC} \mathrm{yr}^{-1}$ (Rödenbeck et al., 2014) and $\pm 0.41 \mathrm{GtC} \mathrm{yr}^{-1}$ (Landschützer et al., 2015), compared to $\pm 0.29 \mathrm{GtC} \mathrm{yr}^{-1}$ for the normalised model ensemble. The standard deviation includes a component of trend and decadal variability in addition to interannual variability, and their relative influence differs across estimates. The phase is generally consistent between estimates, with a higher ocean $\mathrm{CO}_{2}$ sink during El Niño events. The annual data-based estimates correlate with the ocean $\mathrm{CO}_{2}$ sink estimated here with a correlation of $r=0.71$ ( 0.51 to 0.77 for individual models), and $r=0.81$ ( 0.66 to 0.79$)$ for the data-based estimates of Rödenbeck et al. (2014) and Landschützer et al. (2015), respectively (simple linear regression), with their mutual correlation at 0.65 . The agreement is better for decadal variability than for interannual variability. The use of annual data for the correlation may reduce the strength of the relationship because the dominant source of variability associated with El Niño events is less than one year. We assess a medium confidence level to the annual ocean $\mathrm{CO}_{2}$ sink and its uncertainty because they are based on multiple lines of evidence, and the results are consistent in that the interannual variability in the model and data-based estimates are all generally small compared to the variability in the growth rate of atmospheric $\mathrm{CO}_{2}$ concentration.

\subsection{Terrestrial $\mathrm{CO}_{2}$ sink}

The difference between, on the one hand, fossil fuel $\left(E_{\mathrm{FF}}\right)$ and land-use-change emissions $\left(E_{\mathrm{LUC}}\right)$ and, on the other hand, the growth rate in atmospheric $\mathrm{CO}_{2}$ concentration $\left(G_{\mathrm{ATM}}\right)$ and the ocean $\mathrm{CO}_{2}$ sink $\left(S_{\mathrm{OCEAN}}\right)$ is attributable to the net sink of $\mathrm{CO}_{2}$ in terrestrial vegetation and soils $\left(S_{\text {LAND }}\right)$, within the given uncertainties (Eq. 1). Thus, this sink can be estimated as the residual of the other terms in the mass balance budget, as well as directly calculated us- ing DGVMs. The residual land sink ( $\left.S_{\mathrm{LAND}}\right)$ is thought to be in part because of the fertilising effect of rising atmospheric $\mathrm{CO}_{2}$ on plant growth, $\mathrm{N}$ deposition, and effects of climate change such as the lengthening of the growing season in northern temperate and boreal areas. $S_{\text {LAND }}$ does not include gross land sinks directly resulting from land-use change (e.g. regrowth of vegetation) as these are estimated as part of the net land-use flux $\left(E_{\mathrm{LUC}}\right)$. System boundaries make it difficult to exactly attribute $\mathrm{CO}_{2}$ fluxes on land between $S_{\text {LAND }}$ and $E_{\mathrm{LUC}}$ (Erb et al., 2013), and by design most of the uncertainties in our method are allocated to $S_{\text {LAND }}$ for those processes that are poorly known or represented in models.

\subsubsection{Residual of the budget}

For 1959-2015, the terrestrial carbon sink was estimated from the residual of the other budget terms by rearranging Eq. (1):

$S_{\mathrm{LAND}}=E_{\mathrm{FF}}+E_{\mathrm{LUC}}-\left(G_{\mathrm{ATM}}+S_{\mathrm{OCEAN}}\right)$.

The uncertainty in $S_{\text {LAND }}$ is estimated annually from the root sum of squares of the uncertainty in the right-hand terms assuming the errors are not correlated. The uncertainty averages to $\pm 0.8 \mathrm{GtC} \mathrm{yr}^{-1}$ over $1959-2015$ (Table 7). $S_{\text {LAND }}$ estimated from the residual of the budget includes, by definition, all the missing processes and potential biases in the other components of Eq. (8).

\subsubsection{DGVMs}

A comparison of the residual calculation of $S_{\mathrm{LAND}}$ in Eq. (8) with estimates from DGVMs as used to estimate $E_{\mathrm{LUC}}$ in Sect. 2.2.3, but here excluding the effects of changes in land cover (using a constant pre-industrial land-cover distribution), provides an independent estimate of the consistency of $S_{\text {LAND }}$ with our understanding of the functioning of the terrestrial vegetation in response to $\mathrm{CO}_{2}$ and climate variability (Table 7). As described in Sect. 2.2.3, the DGVM runs that exclude the effects of changes in land cover include all climate variability and $\mathrm{CO}_{2}$ effects over land, but they do not include reductions in $\mathrm{CO}_{2}$ sink capacity associated with human activity directly affecting changes in vegetation cover and management, which by design is allocated to $E_{\mathrm{LUC}}$. This effect has been estimated to have led to a reduction in the terrestrial sink by $0.5 \mathrm{GtC} \mathrm{yr}^{-1}$ since 1750 (Gitz and Ciais, 2003). The models in this configuration estimate the mean and variability of $S_{\text {LAND }}$ based on atmospheric $\mathrm{CO}_{2}$ and climate, and thus both terms can be compared to the budget residual. We apply three criteria for minimum model realism by including only those models with (1) steady state after spin-up; (2) where available, net land fluxes $\left(S_{\mathrm{LAND}}-E_{\mathrm{LUC}}\right)$ that are a carbon sink over the 1990s as constrained by global atmospheric and oceanic observations (Keeling and Manning, 2014; Wanninkhof et al., 2013); and (3) where available, global $E_{\mathrm{LUC}}$ that is a carbon source over the $1990 \mathrm{~s}$. 
Fourteen models met criteria (1), and five of the models that provided $E_{\text {LUC }}$ met all three criteria.

The standard deviation of the annual $\mathrm{CO}_{2}$ sink across the DGVMs' averages to $\pm 0.8 \mathrm{GtC} \mathrm{yr}^{-1}$ for the period 1959 to 2015. The model mean, over different decades, correlates with the budget residual with $r=0.68$ ( 0.51 to $r=0.77$ for individual models). The standard deviation is similar to that of the five model ensembles presented in Le Quéré et al. (2009), but the correlation is improved compared to $r=0.54$ obtained in the earlier study. The DGVM results suggest that the sum of our knowledge on annual $\mathrm{CO}_{2}$ emissions and their partitioning is plausible (see Sect. 4), and provide insight on the underlying processes and regional breakdown. However, as the standard deviation across the DGVMs ( $0.8 \mathrm{GtC} \mathrm{yr}^{-1}$ on average) is of the same magnitude as the combined uncertainty due to the other components $\left(E_{\mathrm{FF}}\right.$, $E_{\text {LUC }}, G_{\text {ATM }}, S_{\text {OCEAN }}$; Table 7 ), the DGVMs do not provide further reduction of uncertainty in the annual terrestrial $\mathrm{CO}_{2}$ sink compared to the residual of the budget (Eq. 8). Yet, DGVM results are largely independent of the residual of the budget, and it is worth noting that the residual method and ensemble mean DGVM results are consistent within their respective uncertainties. We attach a medium confidence level to the annual land $\mathrm{CO}_{2}$ sink and its uncertainty because the estimates from the residual budget and averaged DGVMs match well within their respective uncertainties, and the estimates based on the residual budget are primarily dependent on $E_{\mathrm{FF}}$ and $G_{\mathrm{ATM}}$, both of which are well constrained.

\subsection{The atmospheric perspective}

The worldwide network of atmospheric measurements can be used with atmospheric inversion methods to constrain the location of the combined total surface $\mathrm{CO}_{2}$ fluxes from all sources, including fossil and land-use-change emissions and land and ocean $\mathrm{CO}_{2}$ fluxes. The inversions assume $E_{\mathrm{FF}}$ to be well known, and they solve for the spatial and temporal distribution of land and ocean fluxes from the residual gradients of $\mathrm{CO}_{2}$ between stations that are not explained by emissions. Inversions used atmospheric $\mathrm{CO}_{2}$ data to the end of 2015 (including preliminary values in some cases), and three atmospheric $\mathrm{CO}_{2}$ inversions (Table 6) to infer the total $\mathrm{CO}_{2}$ flux over land regions, and the distribution of the total land and ocean $\mathrm{CO}_{2}$ fluxes for the mid- to high-latitude Northern Hemisphere $\left(30-90^{\circ} \mathrm{N}\right)$, tropics $\left(30^{\circ} \mathrm{S}-30^{\circ} \mathrm{N}\right)$ and mid- to high-latitude region of the Southern Hemisphere (30-90 $\mathrm{S}$ ). We focus here on the largest and most consistent sources of information and use these estimates to comment on the consistency across various data streams and process-based estimates.

\section{Atmospheric inversions}

The three inversion systems used in this release are the CarbonTracker (Peters et al., 2010), the Jena CarboScope (Rö- denbeck, 2005), and CAMS (Chevallier et al., 2005). See Table 6 for version numbers. They are based on the same Bayesian inversion principles that interpret the same, for the most part, observed time series (or subsets thereof), but use different methodologies that represent some of the many approaches used in the field. This mainly concerns the time resolution of the estimates (i.e. weekly or monthly), spatial breakdown (i.e. grid size), assumed correlation structures, and mathematical approach. The details of these approaches are documented extensively in the references provided. Each system uses a different transport model, which was demonstrated to be a driving factor behind differences in atmospheric-based flux estimates, and specifically their global distribution (Stephens et al., 2007).

The three inversions use atmospheric $\mathrm{CO}_{2}$ observations from various flask and in situ networks. They prescribe spatial and global $E_{\mathrm{FF}}$ that can vary from that presented here. The CarbonTracker and CAMS inversions prescribed the same global $E_{\mathrm{FF}}$ as in Sect. 2.1.1, during 2010-2015 for CarbonTracker and during 1979-2015 in CAMS. The Jena CarboScope inversion uses $E_{\mathrm{FF}}$ from EDGAR (2011) v4.2. Different spatial and temporal distributions of $E_{\mathrm{FF}}$ were prescribed in each inversion.

Given their prescribed $E_{\mathrm{FF}}$, each inversion estimates natural fluxes from a similar set of surface $\mathrm{CO}_{2}$ measurement stations, and CarbonTracker additionally uses two sites of aircraft $\mathrm{CO}_{2}$ vertical profiles over the Amazon and Siberia, regions where surface observations are sparse. The atmospheric transport models of each inversion are TM5 for CarbonTracker, TM3 for Jena CarboScope, and LMDZ for CAMS. These three models are based on the same ECMWF wind fields. The three inversions use different prior natural fluxes, which partly influences their optimised fluxes. CAMS assumes that the prior land flux is zero on the annual mean in each grid cell of the transport model, so that any sink or source on land is entirely reflecting the information brought by atmospheric measurements. CarbonTracker simulates a small prior sink on land from the SIBCASA model that results from regrowth following fire disturbances of an otherwise net zero biosphere. Jena CarboScope assumes a prior sink on land as well from the LPJ model. Inversion results for the sum of natural ocean and land fluxes (Fig. 8) are more constrained in the Northern Hemisphere $(\mathrm{NH})$ than in the tropics, because of the higher measurement stations density in the $\mathrm{NH}$.

Finally, results from atmospheric inversions include the natural $\mathrm{CO}_{2}$ fluxes from rivers (which need to be taken into account to allow comparison to other sources) and chemical oxidation of reactive carbon-containing gases (which are neglected here). These inverse estimates are not truly independent of the other estimates presented here as the atmospheric observations include a set of observations used to estimate the global growth rate in atmospheric $\mathrm{CO}_{2}$ concentration (Sect. 2.3). However, they provide new information on the regional distribution of fluxes. 
We focus the analysis on two known strengths of the inverse approach: the derivation of the year-to-year changes in total land fluxes $\left(S_{\mathrm{LAND}}-E_{\mathrm{LUC}}\right)$ consistent with the whole network of atmospheric observations, and the spatial breakdown of land and ocean fluxes $\left(S_{\mathrm{LAND}}-E_{\mathrm{LUC}}+S_{\text {OCEAN }}\right)$ across large regions of the globe. The spatial breakdown is discussed in Sect. 3.1.3.

\subsection{Processes not included in the global carbon budget}

\subsubsection{Contribution of anthropogenic $\mathrm{CO}$ and $\mathrm{CH}_{4}$ to the global carbon budget}

Anthropogenic emissions of $\mathrm{CO}$ and $\mathrm{CH}_{4}$ to the atmosphere are eventually oxidised to $\mathrm{CO}_{2}$ and thus are part of the global carbon budget. These contributions are omitted in Eq. (1), but an attempt is made in this section to estimate their magnitude and identify the sources of uncertainty. Anthropogenic $\mathrm{CO}$ emissions are from incomplete fossil fuel and biofuel burning and deforestation fires. The main anthropogenic emissions of fossil $\mathrm{CH}_{4}$ that matter for the global carbon budget are the fugitive emissions of coal, oil, and gas upstream sectors (see below). These emissions of $\mathrm{CO}$ and $\mathrm{CH}_{4}$ contribute a net addition of fossil carbon to the atmosphere.

In our estimate of $E_{\mathrm{FF}}$ we assumed (Sect. 2.1.1) that all the fuel burned is emitted as $\mathrm{CO}_{2}$; thus, $\mathrm{CO}$ anthropogenic emissions and their atmospheric oxidation into $\mathrm{CO}_{2}$ within a few months are already counted implicitly in $E_{\mathrm{FF}}$ and should not be counted twice (same for $E_{\mathrm{LUC}}$ and anthropogenic $\mathrm{CO}$ emissions by deforestation fires). Anthropogenic emissions of fossil $\mathrm{CH}_{4}$ are not included in $E_{\mathrm{FF}}$, because these fugitive emissions are not included in the fuel inventories. Yet they contribute to the annual $\mathrm{CO}_{2}$ growth rate after $\mathrm{CH}_{4}$ gets oxidised into $\mathrm{CO}_{2}$. Anthropogenic emissions of fossil $\mathrm{CH}_{4}$ represent $15 \%$ of total $\mathrm{CH}_{4}$ emissions (Kirschke et al., 2013) that is $0.061 \mathrm{GtC} \mathrm{yr}^{-1}$ for the past decade. Assuming steady state, these emissions are all converted to $\mathrm{CO}_{2}$ by $\mathrm{OH}$ oxidation and thus explain $0.06 \mathrm{GtC} \mathrm{yr}^{-1}$ of the global $\mathrm{CO}_{2}$ growth rate in the past decade, or $0.07-0.1 \mathrm{GtC} \mathrm{yr}^{-1}$ using the higher $\mathrm{CH}_{4}$ emissions reported recently (Schwietzke et al., 2016).

Other anthropogenic changes in the sources of $\mathrm{CO}$ and $\mathrm{CH}_{4}$ from wildfires, biomass, wetlands, ruminants, or permafrost changes are similarly assumed to have a small effect on the $\mathrm{CO}_{2}$ growth rate.

\subsubsection{Anthropogenic carbon fluxes in the land to ocean aquatic continuum}

The approach used to determine the global carbon budget considers only anthropogenic $\mathrm{CO}_{2}$ emissions and their partitioning among the atmosphere, ocean, and land. In this analysis, the land and ocean reservoirs that take up anthropogenic $\mathrm{CO}_{2}$ from the atmosphere are conceived as independent carbon storage repositories. This approach omits the fact that carbon is continuously displaced from the land to the ocean through the land-ocean aquatic continuum (LOAC) comprising freshwaters, estuaries, and coastal areas (Bauer et al., 2013; Regnier et al., 2013). A significant fraction of this lateral carbon flux is entirely "natural" and is thus a steadystate component of the pre-industrial carbon cycle. However, changes in environmental conditions and land-use change have caused an increase in the lateral transport of carbon into the LOAC - a perturbation that is relevant for the global carbon budget presented here.

The results of the analysis of Regnier et al. (2013) can be summarised in two points of relevance for the anthropogenic $\mathrm{CO}_{2}$ budget. First, the anthropogenic perturbation has increased the organic carbon export from terrestrial ecosystems to the hydrosphere at a rate of $1.0 \pm 0.5 \mathrm{GtC} \mathrm{yr}^{-1}$, mainly owing to enhanced carbon export from soils. Second, this exported anthropogenic carbon is partly respired through the LOAC, partly sequestered in sediments along the LOAC and, to a lesser extent, transferred in the open ocean where it may accumulate. The increase in storage of land-derived organic carbon in the LOAC and open ocean combined is estimated by Regnier et al. (2013) at $0.65 \pm 0.35 \mathrm{GtC} \mathrm{yr}^{-1}$. The implication of a substantial LOAC carbon accumulation is that $S_{\text {LAND }}$ corresponds to carbon sequestered both in land ecosystems and in LOAC. We do not attempt to separate these two storage components in our study focused on $S_{\text {LAND. }}$

\section{Results}

\subsection{Global carbon budget averaged over decades and its variability}

The global carbon budget averaged over the last decade (2006-2015) is shown in Fig. 2. For this time period, 91\% of the total emissions $\left(E_{\mathrm{FF}}+E_{\mathrm{LUC}}\right)$ were caused by fossil fuels and industry, and $9 \%$ by land-use change. The total emissions were partitioned among the atmosphere (44\%), ocean $(26 \%)$, and land $(30 \%)$. All components except landuse-change emissions have grown since 1959 (Figs. 3 and 4 ), with important interannual variability in the growth rate in atmospheric $\mathrm{CO}_{2}$ concentration and in the land $\mathrm{CO}_{2}$ sink (Fig. 4) and some decadal variability in all terms (Table 8).

\subsection{1 $\mathrm{CO}_{2}$ emissions}

Global $\mathrm{CO}_{2}$ emissions from fossil fuels and industry have increased every decade from an average of $3.1 \pm 0.2 \mathrm{GtC} \mathrm{yr}^{-1}$ in the 1960 s to an average of $9.3 \pm 0.5 \mathrm{GtC} \mathrm{yr}^{-1}$ during 2006-2015 (Table 8 and Fig. 5). The growth rate in these emissions decreased between the 1960s and the 1990s, with $4.5 \% \mathrm{yr}^{-1}$ in the $1960 \mathrm{~s}$ (1960-1969), $2.8 \% \mathrm{yr}^{-1}$ in the 1970s (1970-1979), $1.9 \% \mathrm{yr}^{-1}$ in the 1980s (1980-1989), and $1.1 \% \mathrm{yr}^{-1}$ in the $1990 \mathrm{~s}$ (1990-1999). After this period, the growth rate began increasing again in the 2000s at an average growth rate of $3.5 \% \mathrm{yr}^{-1}$, decreasing to $1.8 \% \mathrm{yr}^{-1}$ 


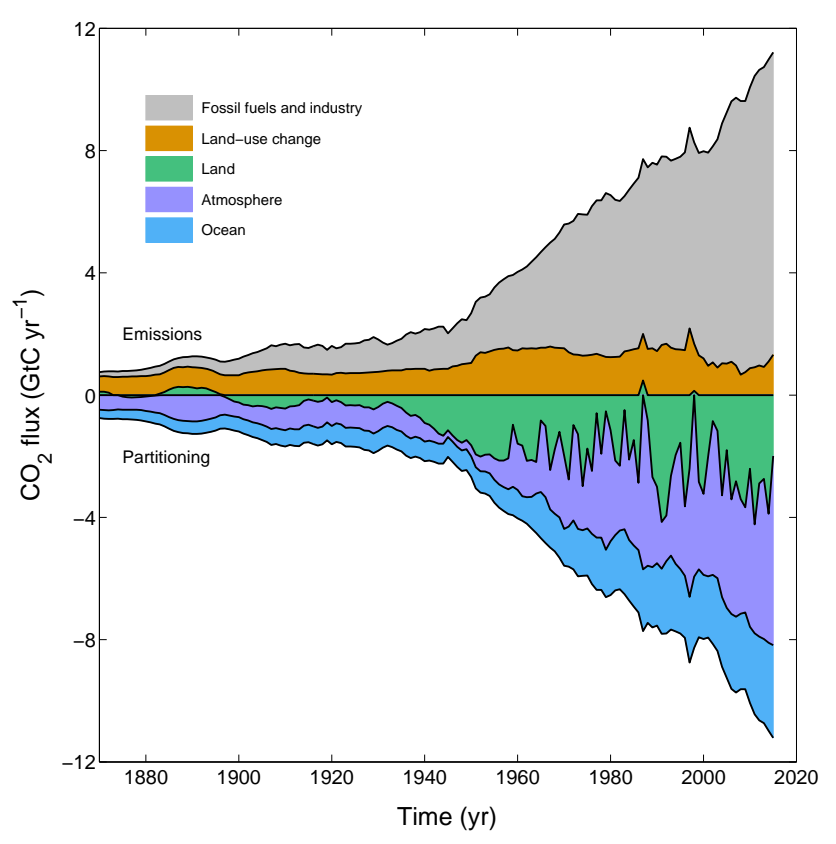

Figure 3. Combined components of the global carbon budget illustrated in Fig. 2 as a function of time, for emissions from fossil fuels and industry ( $E_{\mathrm{FF}}$; grey) and emissions from land-use change ( $E_{\mathrm{LUC}}$; brown), as well as their partitioning among the atmosphere ( $G_{\text {ATM }}$; purple), land ( $S_{\text {LAND }}$; green), and oceans ( $S_{\text {OCEAN }}$; dark blue). All time series are in $\mathrm{GtC} \mathrm{yr}^{-1}$. $G_{\text {ATM }}$ and $S_{\text {OCEAN }}$ (and by construction also $S_{\text {LAND }}$ ) prior to 1959 are based on different methods. The primary data sources for fossil fuels and industry are from Boden and Andres (2016), with uncertainty of about $\pm 5 \%( \pm 1 \sigma)$; land-use-change emissions are from Houghton et al. (2012) with uncertainties of about $\pm 30 \%$; growth rate in atmospheric $\mathrm{CO}_{2}$ concentration prior to 1959 is from Joos and Spahni (2008) with uncertainties of about $\pm 1-1.5 \mathrm{GtC}$ decade $^{-1}$ or $\pm 0.1-0.15 \mathrm{GtC} \mathrm{yr}^{-1}$ (Bruno and Joos, 1997), and from Dlugokencky and Tans (2016) from 1959 with uncertainties of about $\pm 0.2 \mathrm{GtC} \mathrm{yr}^{-1}$; the ocean sink prior to 1959 is from Khatiwala et al. (2013) with uncertainty of about $\pm 30 \%$, and from this study from 1959 with uncertainties of about $\pm 0.5 \mathrm{GtC} \mathrm{yr}^{-1}$; and the residual land sink is obtained by difference (Eq. 8), resulting in uncertainties of about $\pm 50 \%$ prior to 1959 and $\pm 0.8 \mathrm{GtC} \mathrm{yr}^{-1}$ after that. See the text for more details of each component and their uncertainties.

for the last decade (2006-2015). In contrast, $\mathrm{CO}_{2}$ emissions from land-use change have remained relatively constant at around $1.3 \pm 0.5 \mathrm{GtC} \mathrm{yr}^{-1}$ during 1960-2015. A decrease in emissions from land-use change is suggested between the 1990s and 2000s by the combination of bookkeeping and fire-based emissions used here (Table 7), but it is highly uncertain due to uncertainty in the underlying land-coverchange data. This decrease is not found in the current ensemble of the DGVMs (Fig. 6), which are otherwise consistent with the bookkeeping method within their respective uncertainty (Table 7). The decrease is also not found in the study of tropical deforestation of Achard et al. (2014), where the fluxes in the 1990s were similar to those of the 2000s and
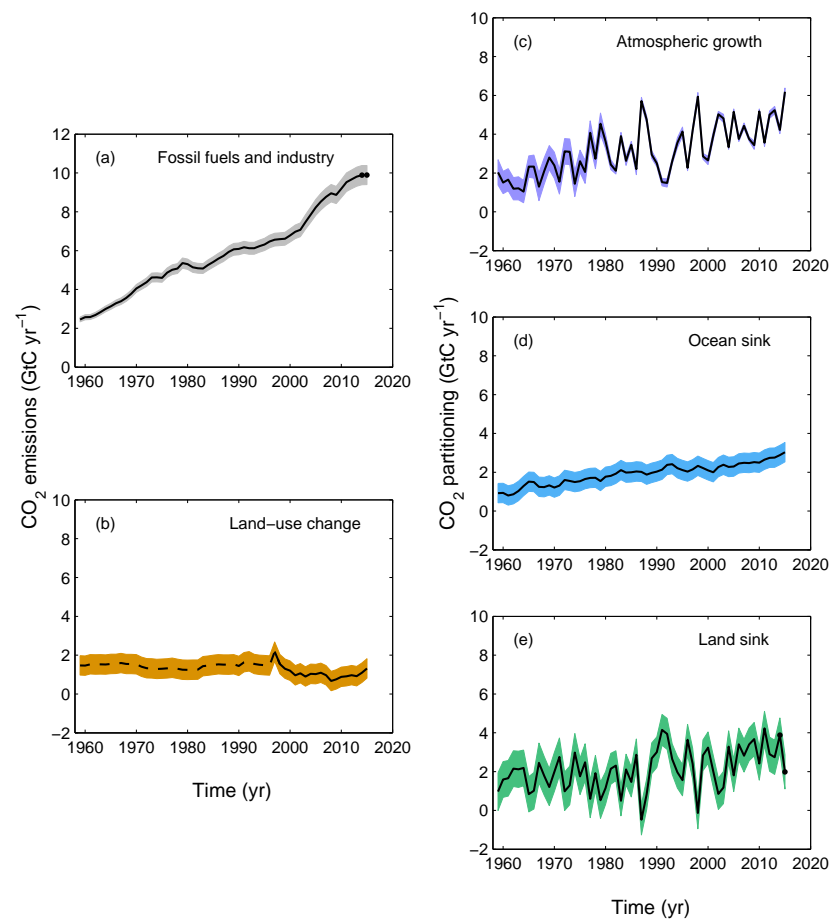

Figure 4. Components of the global carbon budget and their uncertainties as a function of time, presented individually for (a) emissions from fossil fuels and industry $\left(E_{\mathrm{FF}}\right),(\mathbf{b})$ emissions from landuse change $\left(E_{\mathrm{LUC}}\right)$, (c) growth rate in atmospheric $\mathrm{CO}_{2}$ concentration $\left(G_{\mathrm{ATM}}\right),(\mathbf{d})$ the ocean $\mathrm{CO}_{2}$ sink ( $S_{\mathrm{OCEAN}}$; positive indicates a flux from the atmosphere to the ocean), and (e) the land $\mathrm{CO}_{2}$ sink ( $S_{\mathrm{LAND}}$; positive indicates a flux from the atmosphere to the land). All time series are in $\mathrm{GtC} \mathrm{yr}^{-1}$ with the uncertainty bounds representing $\pm 1 \sigma$ in shaded colour. Data sources are as in Fig. 3. The black dots in (a, e) show values for 2014 and 2015 that originate from a different data set to the remainder of the data, while the dashed line in (b) highlights the start of satellite data use to estimate the interannual variability and extend the series in time (see text).

outside our uncertainty range. A new study based on FAO data to 2015 (Federici et al., 2015) suggests that $E_{\mathrm{LUC}}$ decreased during 2011-2015 compared to 2001-2010.

\subsubsection{Partitioning among the atmosphere, ocean, and land}

Emissions are partitioned among the atmosphere, ocean, and land (Eq. 1). The growth rate in atmospheric $\mathrm{CO}_{2}$ level increased from $1.7 \pm 0.1 \mathrm{GtC} \mathrm{yr}^{-1}$ in the $1960 \mathrm{~s}$ to $4.5 \pm 0.1 \mathrm{GtC} \mathrm{yr}^{-1}$ during 2006-2015 with important decadal variations (Table 8). Both ocean and land $\mathrm{CO}_{2}$ sinks increased roughly in line with the atmospheric increase, but with significant decadal variability on land (Table 8). The ocean $\mathrm{CO}_{2}$ sink increased from $1.2 \pm 0.5 \mathrm{GtC} \mathrm{yr}^{-1}$ in the 1960 s to $2.6 \pm 0.5 \mathrm{GtC} \mathrm{yr}^{-1}$ during 2006-2015, with interannual variations of the order of a few tenths of $\mathrm{GtC} \mathrm{yr}^{-1}$ 


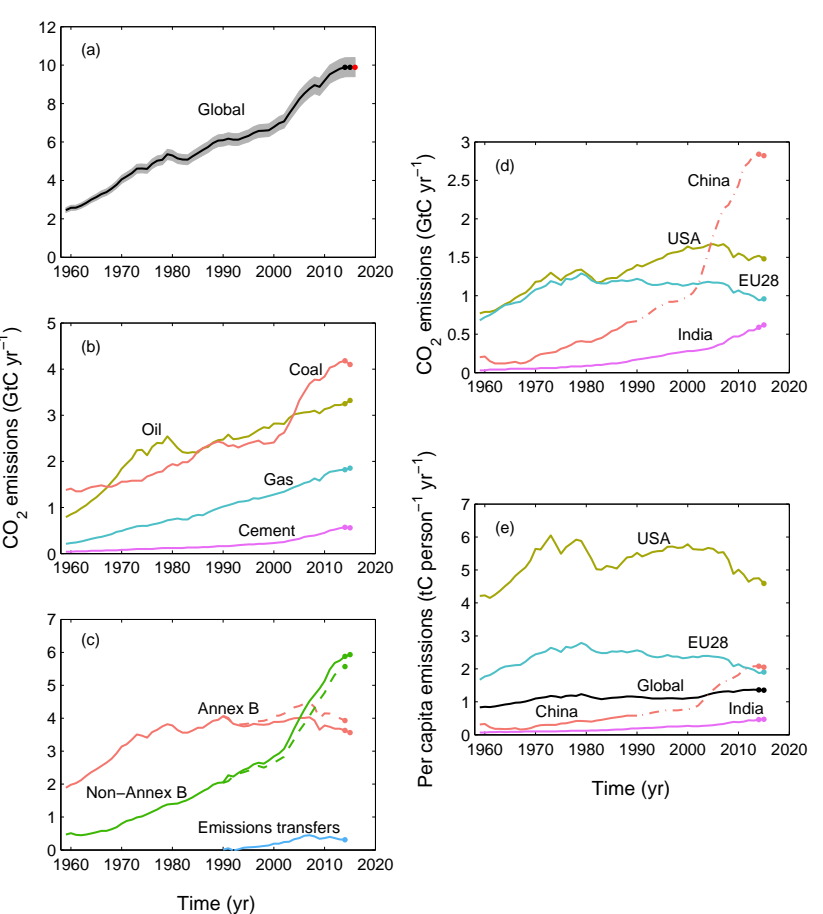

Figure 5. $\mathrm{CO}_{2}$ emissions from fossil fuels and industry for (a) the globe, including an uncertainty of $\pm 5 \%$ (grey shading), the emissions extrapolated using BP energy statistics (black dots), and the emissions projection for year 2016 based on GDP projection (red dot). (b) Global emissions by fuel type, including coal (salmon), oil (olive), gas (turquoise), and cement (purple), and excluding gas flaring which is small $(0.6 \%$ in 2013). (c) Territorial (solid line) and consumption (dashed line) emissions for the countries listed in Annex B of the Kyoto Protocol (salmon lines; mostly advanced economies with emissions limitations) vs. non-Annex B countries (green lines); also shown are the emissions transfer from non-Annex B to Annex B countries (light-blue line). (d) Territorial $\mathrm{CO}_{2}$ emissions for the top three country emitters (USA - olive; China - salmon; India - purple) and for the European Union (EU; turquoise for the 28 member states of the EU as of 2012). (e) Per capita emissions for the top three country emitters and the EU (all colours as in panel (d) and the world (black). In (b-e), the dots show the data that were extrapolated from BP energy statistics for

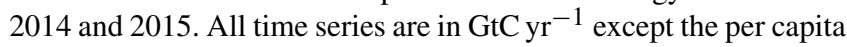
emissions (e), which are in tonnes of carbon per person per year $\left(\mathrm{tC}\right.$ person $\left.{ }^{-1} \mathrm{yr}^{-1}\right)$. Territorial emissions are primarily from Boden and Andres (2016) except for national data for the USA and EU28 for 1990-2014, which are reported by the countries to the UNFCCC as detailed in the text, and for China from 1990, which are estimated here from BP energy statistics (the latter shown as a dashdot line); consumption-based emissions are updated from Peters et al. (2011a). See Sect. 2.1.1 for details of the calculations and data sources. generally showing an increased ocean sink during El Niño events (i.e. 1982-1983, 1997-1998, 2015-2016) (Fig. 7; Rödenbeck et al., 2014). Although there is some coherence between the ocean models and data products and among data products regarding the mean, decadal variability, and trend, the ocean models and data products show poor agreement for interannual variability (Sect. 2.4.3 and Fig. 7). As shown in Fig. 7, the two data products and most model estimates produce a mean $\mathrm{CO}_{2}$ sink for the 1990s that is below the mean assessed by the IPCC from indirect (but arguably more reliable) observations (Denman et al., 2007; Sect. 2.4.1). This discrepancy suggests we may need to reassess estimates of the mean ocean carbon sinks, with some implications for the cumulative carbon budget (Landschützer et al., 2016).

The residual terrestrial $\mathrm{CO}_{2}$ sink increased from $1.7 \pm 0.7 \mathrm{GtC} \mathrm{yr}^{-1}$ in the $1960 \mathrm{~s}$ to $3.1 \pm 0.9 \mathrm{GtC} \mathrm{yr}^{-1}$ during 2006-2015, with important interannual variations of

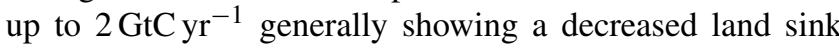
during El Niño events, overcompensating for the increase in ocean sink and accounting for the enhanced growth rate in atmospheric $\mathrm{CO}_{2}$ concentration during El Niño events. The high uptake anomaly around year 1991 is thought to be caused by the effect of the volcanic eruption of Mount Pinatubo on climate and is not generally reproduced by the DGVMs, but it is assigned to the land by the two inverse systems that include this period (Fig. 6). The larger land $\mathrm{CO}_{2}$ sink during 2006-2015 compared to the 1960s is reproduced by all the DGVMs in response to combined atmospheric $\mathrm{CO}_{2}$ increase, climate, and variability, consistent with the budget residual and reflecting a common knowledge of the processes (Table 7). The DGVM ensemble mean of $2.8 \pm 0.7 \mathrm{GtC} \mathrm{yr}^{-1}$ also reproduces the observed mean for the period 2006-2015 calculated from the budget residual (Table 7).

The total $\mathrm{CO}_{2}$ fluxes on land $\left(S_{\mathrm{LAND}}-E_{\mathrm{LUC}}\right)$ constrained by the atmospheric inversions show in general very good agreement with the global budget estimate, as expected given the strong constrains of $G_{\mathrm{ATM}}$ and the small relative uncertainty assumed on $S_{\mathrm{OCEAN}}$ and $E_{\mathrm{FF}}$ by inversions. The total land flux is of similar magnitude for the decadal average, with estimates for 2006-2015 from the three inversions of $2.2,2.3$, and $3.4 \mathrm{GtC} \mathrm{yr}^{-1}$ compared to $2.1 \pm 0.7 \mathrm{GtC} \mathrm{yr}^{-1}$ for the total flux computed with the carbon budget from other terms in Eq. (1) (Table 7). The total land sink from the three inversions is $1.8,1.8$, and $3.0 \mathrm{GtC} \mathrm{yr}^{-1}$ when including a mean river flux adjustment of $0.45 \mathrm{GtC} \mathrm{yr}^{-1}$, though the exact adjustment is in fact smaller because the anthropogenic contribution to river fluxes is only a fraction of the total river flux (Sect. 2.7.2). The interannual variability in the inversions also matched the residual-based $S_{\text {LAND }}$ closely (Fig. 6). The total land flux from the DGVM multi-model mean also compares well with the estimate from the carbon budget and atmospheric inversions, with a decadal mean of $1.7 \pm 0.5 \mathrm{GtC} \mathrm{yr}^{-1}$ (Table 7; 2006-2015), although individual models differ by several GtC for some years (Fig. 6). 

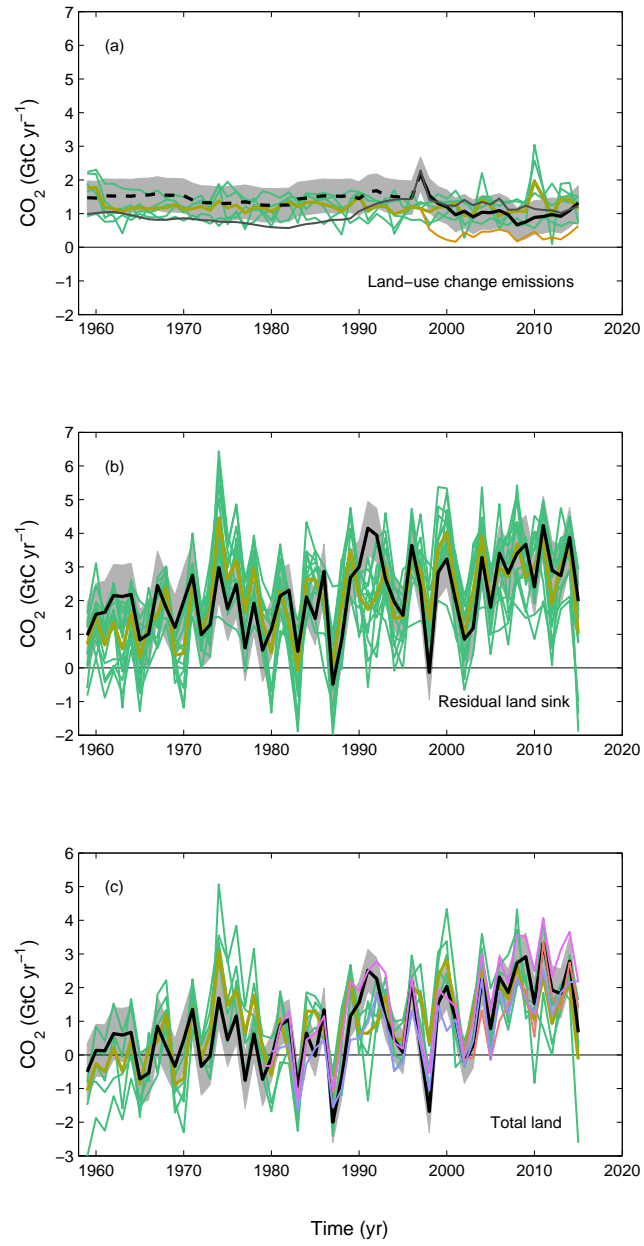

Figure 6. $\mathrm{CO}_{2}$ exchanges between the atmosphere and the terrestrial biosphere. (a) Comparison of the global carbon budget values of $\mathrm{CO}_{2}$ emissions from land-use change ( $E_{\mathrm{LUC}}$; black with $\pm 1 \sigma$ uncertainty in grey shading), with $\mathrm{CO}_{2}$ emissions from land-use change showing individual DGVM results (green) and the multimodel mean (olive), as well as fire-based results (orange); land-usechange data prior to 1997 (dashed black) highlights the pre-satellite years; preliminary results using the FAO FRA 2015 (Houghton and Nassikas, 2016) are also shown in dark grey. (b) Land $\mathrm{CO}_{2}$ sink ( $S_{\text {LAND }}$; black with uncertainty in grey shading) showing individual DGVM results (green) and multi-model mean (olive). (c) Total land $\mathrm{CO}_{2}$ fluxes (b-a; black with uncertainty in grey shading), from DGVM results (green) and the multi-model mean (olive), and atmospheric inversions Chevallier et al. (2005; CAMSv15.2) in purple; Rödenbeck et al. (2003; Jena CarboScope, s81_v3.8) in violet; Peters et al. (2010; Carbon Tracker, CTE2016-FT) in salmon; and the carbon balance from Eq. (1) (black). Five DGVMs are plotted in (a) and 14 in (b, c); see Table 5 for the list and Table 6 for the description. In (c) the inversions were corrected for the pre-industrial land sink of $\mathrm{CO}_{2}$ from river input by removing a sink of $0.45 \mathrm{GtC} \mathrm{yr}^{-1}$ (Jacobson et al., 2007). This correction does not take into account the anthropogenic contribution to river fluxes (see Sect. 2.7.2).

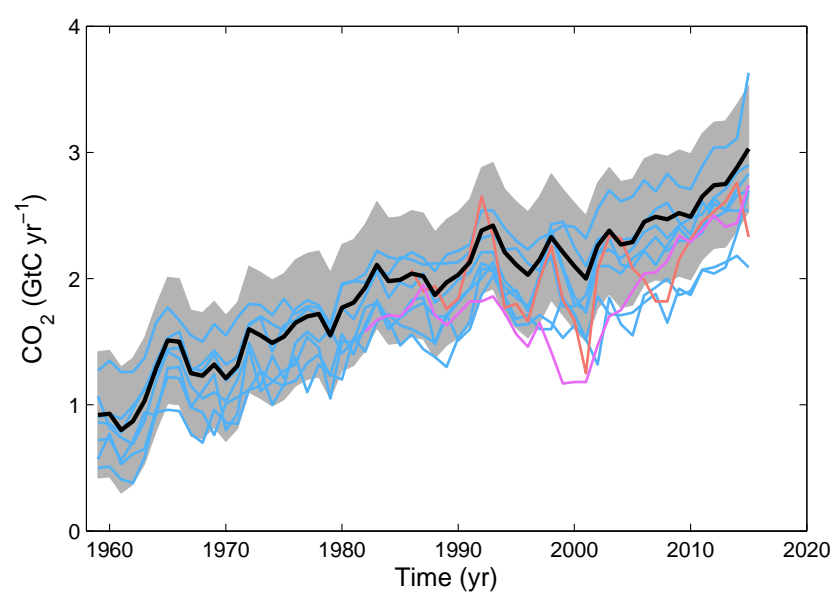

Figure 7. Comparison of the anthropogenic atmosphere-ocean $\mathrm{CO}_{2}$ flux showing the budget values of $S_{\text {OCEAN }}$ (black; with $\pm 1 \sigma$ uncertainty in grey shading), individual ocean models before normalisation (blue), and the two ocean data-based products (Rödenbeck et al. (2014) in salmon and Landschützer et al. (2015) in purple; see Table 6). Both data-based products were adjusted for the pre-industrial ocean source of $\mathrm{CO}_{2}$ from river input to the ocean, which is not present in the models, by adding a sink of $0.45 \mathrm{GtC} \mathrm{yr}^{-1}$ (Jacobson et al., 2007), to make them comparable

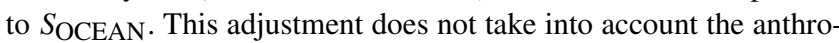
pogenic contribution to river fluxes (see Sect. 2.7.2).

\subsubsection{Regional distribution}

Figure 8 shows the partitioning of the total surface fluxes excluding emissions from fossil fuels and industry ( $S_{\text {LAND }}+$ $\left.S_{\text {OCEAN }}-E_{\mathrm{LUC}}\right)$ according to the process models in the ocean and on land, as well as to the three atmospheric inversions. The total surface fluxes provide information on the regional distribution of those fluxes by latitude bands (Fig. 8). The global mean $\mathrm{CO}_{2}$ fluxes from process models for 20062015 is $4.2 \pm 0.6 \mathrm{GtC} \mathrm{yr}^{-1}$. This is comparable to the fluxes of $4.8 \pm 0.5 \mathrm{GtC} \mathrm{yr}^{-1}$ inferred from the remainder of the carbon budget $\left(E_{\mathrm{FF}}-G_{\mathrm{ATM}}\right.$ in Eq. 1; Table 8) within their respective uncertainties. The total $\mathrm{CO}_{2}$ fluxes from the three inversions range between 4.6 and $4.9 \mathrm{GtC} \mathrm{yr}^{-1}$, consistent with the carbon budget as expected from the constraints on the inversions.

In the south (south of $30^{\circ} \mathrm{S}$ ), the atmospheric inversions and process models all suggest a $\mathrm{CO}_{2}$ sink for 2006-2015 of between 1.2 and $1.6 \mathrm{GtC} \mathrm{yr}^{-1}$ (Fig. 8), although the details of the interannual variability are not fully consistent across methods. The interannual variability in the south is low because of the dominance of ocean area with low variability compared to land areas.

In the tropics $\left(30^{\circ} \mathrm{S}-30^{\circ} \mathrm{N}\right)$, both the atmospheric inversions and process models suggest the carbon balance in this region is close to neutral over the past decade, with fluxes for 2006-2015 ranging between -0.5 and $+0.6 \mathrm{GtC} \mathrm{yr}^{-1}$. Both the process-based models and the inversions consistently al- 

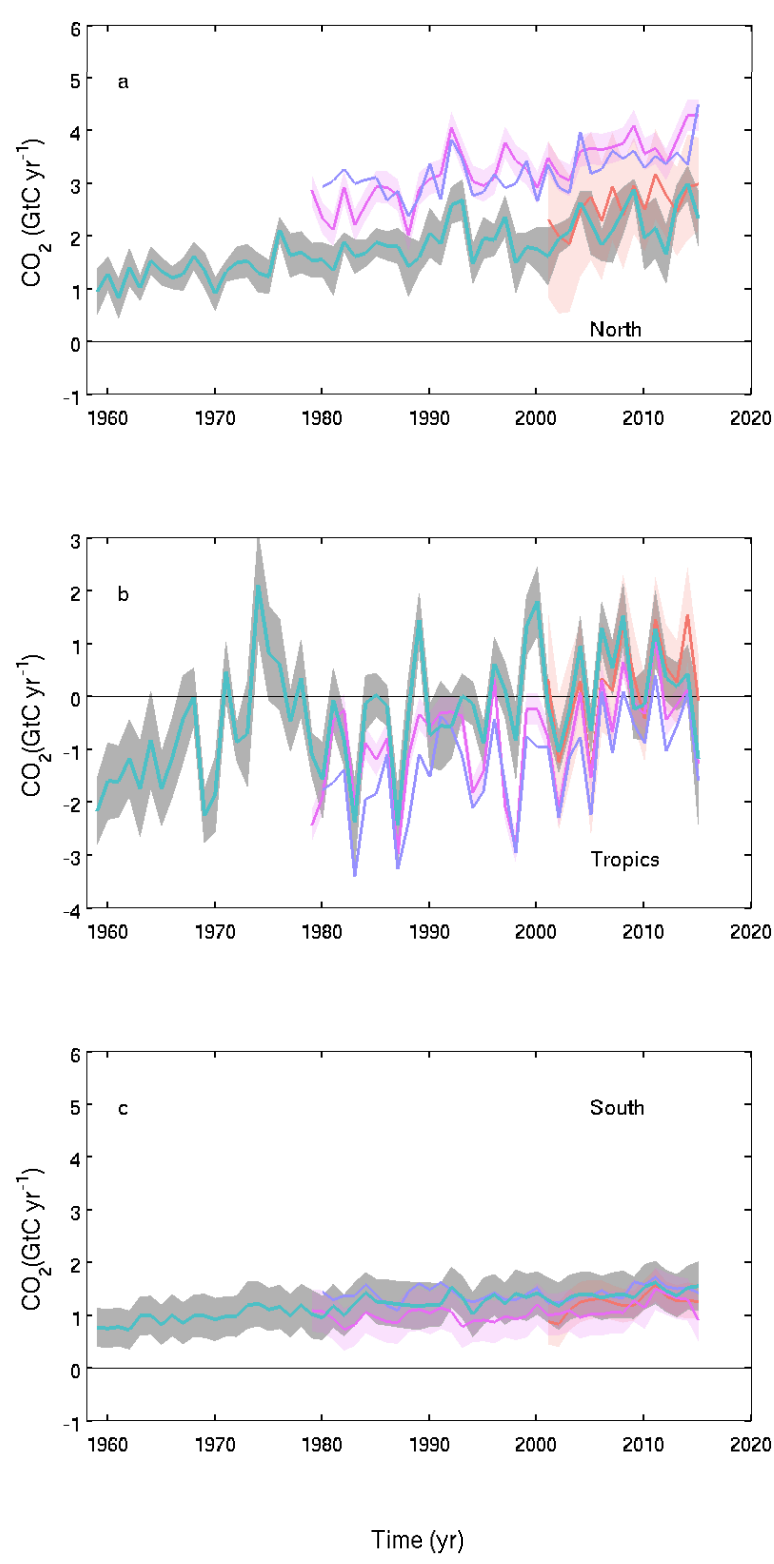

Figure 8. $\mathrm{CO}_{2}$ fluxes between the atmosphere and the surface $\left(S_{\text {OCEAN }}+S_{\text {LAND }}-E_{\text {LUC }}\right)$ by latitude bands for the (a) north (north of $30^{\circ} \mathrm{N}$ ), (b) tropics $\left(30^{\circ} \mathrm{S}-30^{\circ} \mathrm{N}\right)$, and (c) south (south of $\left.30^{\circ} \mathrm{S}\right)$. Estimates from the combination of the multi-model means for the land and oceans are shown (turquoise) with $\pm 1 \sigma$ of the model ensemble (in grey). Results from the three atmospheric inversions are shown from Chevallier et al. (2005; CAMSv15.2) in purple, Rödenbeck et al. (2003; Jena CarboScope, s81_v3.8) in blue, and Peters et al. (2010; CarbonTracker, CTE2016-FT) in salmon; see Table 6. Where available, the uncertainty in the inversions is also shown.

locate more year-to-year variability in $\mathrm{CO}_{2}$ fluxes to the tropics compared to the north (north of $30^{\circ} \mathrm{N}$; Fig. 8), this variability being dominated by land fluxes.

In the north (north of $30^{\circ} \mathrm{N}$ ), the inversions and process models are not in agreement on the magnitude of the $\mathrm{CO}_{2}$ sink with the ensemble mean of the process models suggesting a total Northern Hemisphere sink for 2006-2015 of $2.3 \pm 0.4 \mathrm{GtC} \mathrm{yr}^{-1}$, while the three inversions estimate a sink of $2.7,3.8$, and $3.8 \mathrm{GtC} \mathrm{yr}^{-1}$. The mean difference can only partly be explained by the influence of river fluxes, which is seen by the inversions but not included in the process models, as this flux in the Northern Hemisphere would be less than $0.45 \mathrm{GtC} \mathrm{yr}^{-1}$, particularly when only the anthropogenic contribution to river fluxes is accounted for. The CarbonTracker inversion is close to the one standard deviation of the process models for the mean sink during their overlap period. CAMS and Jena CarboScope give a higher sink in the north than the process models, and a correspondingly higher source in the tropics. Differences between CarbonTracker and CAMS, Jena CarboScope may be related to differences in inter-hemispheric mixing time of their transport models, and other inversion settings. Differences between the mean fluxes of CAMS, Jena CarboScope, and the ensemble of process models cannot be explained easily. They could reflect a bias either in these two inversions or in missing processes or biases in the process models, such as the lack of adequate parameterisations for forest management in the north and for forest degradation emissions in tropics for the DGVMs.

The estimated contribution of the north and its uncertainty from process models is sensitive both to the ensemble of process models used and to the specifics of each inversion. All three inversions show substantial differences in variability and/or trend, and one inversion shows a substantial difference in the mean Northern Hemisphere sink.

\subsection{Global carbon budget for year 2015}

\subsection{1 $\mathrm{CO}_{2}$ emissions}

Global $\mathrm{CO}_{2}$ emissions from fossil fuels and industry remained nearly constant at $9.9 \pm 0.5 \mathrm{GtC}$ in 2015 (Fig. 5), distributed among coal $(41 \%)$, oil (34\%), gas (19\%), cement $(5.6 \%)$, and gas flaring $(0.7 \%)$. Compared to the previous year, emissions from coal and cement decreased by -1.8 and $-1.9 \%$, respectively, while emissions from oil and gas increased by 1.9 and $1.7 \%$, respectively. Due to lack of data, gas flaring in 2014 and 2015 is assumed the same as 2013.

Growth in emissions in 2015 was not statistically different from zero, at $0.06 \%$ higher than in 2014 , in stark contrast with the decadal average of $1.8 \% \mathrm{yr}^{-1}$ (2006-2015). Growth in 2015 is in the range of our projection change of $-0.6[-1.6$ to +0.5$] \%$ made last year (Le Quéré et al., 2015a) based on national emissions projections for China and the USA, and projections of gross domestic product corrected for $I_{\mathrm{FF}}$ improvements for the rest of the world. However, the specific projection for 2015 for China made last year (likely range of -4.6 to $-1.1 \%$ ) was for a larger decrease in emissions than realised $(-0.7 \%)$. This is due to lower decline in coal production in the last 4 months of the year compared to January-August and to improvements in 
energy content of coal through improvements in the quality of the coal used which were at the top of the range of improvements considered in our projection.

In 2015, the largest contributions to global $\mathrm{CO}_{2}$ emissions were from China (29\%), the USA (15\%), the EU (28 member states; $10 \%)$, and India $(6.3 \%)$. The percentages are the fraction of the global emissions including bunker fuels $(3.2 \%)$. These four regions account for $59 \%$ of global emissions. Growth rates for these countries from 2014 to 2015 were $-0.7 \%$ (China), $-2.6 \%$ (USA), $+1.4 \%$ (EU28), and $+5.2 \%$ (India). The per capita $\mathrm{CO}_{2}$ emissions in 2015 were $1.3 \mathrm{tC}_{\text {person }}{ }^{-1} \mathrm{yr}^{-1}$ for the globe, and were 4.6 (USA), 2.1 (China), 1.9 (EU28), and $0.5 \mathrm{tC}_{\text {person }}{ }^{-1} \mathrm{yr}^{-1}$ (India) for the four highest emitting countries (Fig. 5e).

Territorial emissions in Annex B countries decreased by $-0.2 \% \mathrm{yr}^{-1}$ on average during $1990-2014$. Trends observed for consumption emissions were less monotonic, with $0.8 \% \mathrm{yr}^{-1}$ growth over $1990-2007$ and a $-1.5 \% \mathrm{yr}^{-1} \mathrm{de}-$ crease over 2007-2014 (Fig. 5c). In non-Annex B countries during 1990-2014, territorial emissions have grown at $4.7 \% \mathrm{yr}^{-1}$, while consumption emissions have grown at $4.4 \% \mathrm{yr}^{-1}$. In 1990, $65 \%$ of global territorial emissions were emitted in Annex B countries (33\% in non-Annex B, and $2 \%$ in bunker fuels used for international shipping and aviation), while in 2014 this had reduced to $37 \%$ (60\% in non-Annex $\mathrm{B}$, and $3 \%$ in bunker fuels). In terms of consumption emissions this split was $67 \%$ in 1990 and $41 \%$ in 2014 (33 to $59 \%$ in non-Annex B). The difference between territorial and consumption emissions (the net emission transfer via international trade) from non-Annex B to Annex B countries has increased from near zero in 1990 to $0.3 \mathrm{GtC} \mathrm{yr}^{-1}$ around 2005 and remained relatively stable afterwards until the last year available (2014; Fig. 5). The increase in net emission trans-

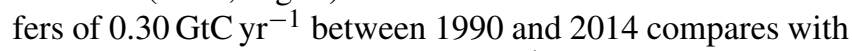
the emission reduction of $0.4 \mathrm{GtC} \mathrm{yr}^{-1}$ in Annex B countries. These results show the importance of net emission transfer via international trade from non-Annex B to Annex B countries, as well as the stabilisation of emissions transfers when averaged over Annex B countries during the past decade. In 2014, the biggest emitters from a consumption perspective were China ( $25 \%$ of the global total), USA (16\%), EU28 $(12 \%)$, and India $(5 \%)$.

Based on fire activity, the global $\mathrm{CO}_{2}$ emissions from landuse change are estimated as $1.3 \pm 0.5 \mathrm{GtC}$ in 2015 , slightly above the 2006-2015 average of $1.0 \pm 0.5 \mathrm{GtC} \mathrm{yr}^{-1}$. The slight rise in $E_{\text {LUC }}$ in 2015 is consistent with estimates of peat fires in Asia based on atmospheric data (Yin et al., 2016). However, the estimated annual variability is not generally consistent between methods, except that all methods estimate that variability in $E_{\mathrm{LUC}}$ is small relative to the variability from $S_{\text {LAND }}$ (Fig. 6a). This could be partly due to the design of the DGVM experiments, which use flux differences between simulations with and without land-cover change, and thus their variability may differ due to, for example, fires in forest regions where the contemporary forest cover is smaller than pre-industrial cover used in the "without land-cover change" runs.

\subsubsection{Partitioning among the atmosphere, ocean, and land}

The growth rate in atmospheric $\mathrm{CO}_{2}$ concentration was $6.3 \pm 0.2 \mathrm{GtC}$ in 2015 (2.97 $\pm 0.09 \mathrm{ppm}$; Fig. 4; Dlugokencky and Tans, 2016). This is well above the 2006-2015 average of $4.5 \pm 0.1 \mathrm{GtC} \mathrm{yr}^{-1}$ and reflects the large interannual variability in the growth rate of atmospheric $\mathrm{CO}_{2}$ concentration associated with El Niño and La Niña events.

The ocean $\mathrm{CO}_{2}$ sink was $3.0 \pm 0.5 \mathrm{GtC} \mathrm{yr}^{-1}$ in 2015 , an increase of $0.15 \mathrm{GtC} \mathrm{yr}^{-1}$ over 2015 according to ocean models. Five of the seven ocean models produce an increase in the ocean $\mathrm{CO}_{2}$ sink in 2015 compared to 2014, with nearzero changes in the last two models (Fig. 7). However, the two data products disagree over changes in the last year, with a decrease of $-0.4 \mathrm{GtC} \mathrm{yr}^{-1}$ found in Rödenbeck et al. (2014) and an increase of $0.3 \mathrm{GtC} \mathrm{yr}^{-1}$ found in Landschützer et al. (2015). Thus, there is no overall consistency in the annual change in the ocean $\mathrm{CO}_{2}$ sink, although there is an indication of increasing convergence among products for the assessment of multi-year changes, as suggested by the time-series correlations reported in Sect. 2.4.3 (see also Landschützer et al., 2015). An increase in the ocean $\mathrm{CO}_{2}$ sink in 2015 would be consistent with the observed El Niño conditions and continued rising atmospheric $\mathrm{CO}_{2}$. All estimates suggest an ocean $\mathrm{CO}_{2}$ sink for 2015 that is larger than their 2006-2015 average.

The terrestrial $\mathrm{CO}_{2}$ sink calculated as the residual from the carbon budget was $1.9 \pm 0.9 \mathrm{GtC}$ in 2015 , well below the $3.1 \pm 0.9 \mathrm{GtC} \mathrm{yr}^{-1}$ averaged over 2006-2015 (Fig. 4), and reflecting the onset of the El Niño conditions in the second half of 2015. The DGVM mean produces a sink of $1.0 \pm 1.4 \mathrm{GtC}$ in 2015, also well below the 2006-2015 average (Table 7). Both models and inversions suggest that the lower sink in 2015 primarily originated in the tropics (Fig. 8).

\subsection{Emission projections and the global carbon budget for year 2016}

\subsection{1 $\mathrm{CO}_{2}$ emissions}

Using separate projections for China, the USA, and the rest of the world as described in Sect. 2.1.4, we project a continued low growth in global $\mathrm{CO}_{2}$ emissions from fossil fuels and cement production in 2016 of $+0.5 \%$ (range of -0.7 to $+2.1 \%$ ) from 2015 levels (Table 9), or $+0.2 \%(-1.0$ to $+1.8 \%$ ) after adjusting for leap year (see Sect. 2.1.3). Our method is imprecise and contains several assumptions that could influence the results beyond the given range, and as such is indicative only. Within the given assumptions, global emissions remain nearly constant at $9.9 \pm 0.5 \mathrm{GtC}$ $\left(36.4 \pm 1.8 \mathrm{GtCO}_{2}\right)$ in 2016 , but they are still $63 \%$ above 
Table 9. Actual $\mathrm{CO}_{2}$ emissions from fossil fuels and industry $\left(E_{\mathrm{FF}}\right)$ compared to projections made the previous year based on world GDP (IMF October 2015) and the fossil fuel intensity of GDP $\left(I_{\mathrm{FF}}\right)$ based on subtracting the $\mathrm{CO}_{2}$ and GDP growth rates. The "Actual" values are the latest estimate available and the "Projected" value for 2016 refers to those presented in this paper. No correction for leap years is applied (Sect. 2.1.3).

\begin{tabular}{|c|c|c|c|c|c|c|}
\hline & \multicolumn{2}{|c|}{$E_{\mathrm{FF}}$} & \multicolumn{2}{|c|}{ GDP } & \multicolumn{2}{|l|}{$I_{\mathrm{FF}}$} \\
\hline & Projected & Actual & Projected & Actual & Projected & Actua \\
\hline $2009^{\mathrm{a}}$ & $-2.8 \%$ & $-1.1 \%$ & $-1.1 \%$ & $-0.05 \%$ & $-1.7 \%$ & $-1.1 \%$ \\
\hline $2010^{\mathrm{b}}$ & $>3 \%$ & $5.7 \%$ & $4.8 \%$ & $5.4 \%$ & $>-1.7 \%$ & $+0.3 \%$ \\
\hline $2011^{\mathrm{c}}$ & $3.1 \pm 1.5 \%$ & $4.1 \%$ & $4.0 \%$ & $4.2 \%$ & $-0.9 \pm 1.5 \%$ & $-0.2 \%$ \\
\hline $2012^{\mathrm{d}}$ & $\begin{array}{r}2.6 \% \mathrm{i} \\
(1.9 \text { to } 3.5)\end{array}$ & $1.7 \%$ & $3.3 \%$ & $3.5 \%$ & $-0.7 \%$ & $-1.8 \%$ \\
\hline $2013^{\mathrm{e}}$ & $\begin{array}{r}2.1 \% \\
(1.1 \text { to } 3.1)\end{array}$ & $1.1 \%$ & $2.9 \%$ & $3.3 \%$ & $-0.8 \%$ & $-2.2 \%$ \\
\hline $2014^{\mathrm{f}}$ & $\begin{array}{r}2.5 \% \\
(1.3 \text { to } 3.5)\end{array}$ & $0.8 \%$ & $3.3 \%$ & $3.0 \%$ & $-0.7 \%$ & $-2.6 \%$ \\
\hline
\end{tabular}

\begin{tabular}{|c|c|c|c|c|c|c|c|c|}
\hline \multicolumn{9}{|c|}{ Change in method } \\
\hline & \multicolumn{2}{|l|}{$E_{\mathrm{FF}}$} & \multicolumn{2}{|c|}{$E_{\mathrm{FF}}$ (China) } & \multicolumn{2}{|c|}{$E_{\mathrm{FF}}(\mathrm{USA})$} & \multicolumn{2}{|c|}{$E_{\mathrm{FF}}$ (rest of world) } \\
\hline & Projected & Actual & Projected & Actual & Projected & Actual & Projected & Actual \\
\hline $2015^{\mathrm{g}}$ & $\begin{array}{r}-0.6 \% \\
(-1.6 \text { to } 0.5)\end{array}$ & $0.05 \%$ & $\begin{array}{r}-3.9 \% \\
(-4.6 \text { to }-1.1)\end{array}$ & $-0.7 \%$ & $\begin{array}{r}-1.5 \% \\
(-5.5 \text { to } 0.3)\end{array}$ & $-2.6 \%$ & $\begin{array}{r}1.2 \% \\
(-0.2 \text { to } 2.6)\end{array}$ & $1.2 \%$ \\
\hline $2016^{h}$ & $\begin{array}{r}+0.5 \% \text { i } \\
(-1.7 \text { to }+2.1)\end{array}$ & - & $\begin{array}{r}-0.2 \% \mathrm{i} \\
(-3.5 \text { to }+1.6)\end{array}$ & - & $\begin{array}{r}-1.4 \% \mathrm{i} \\
(-3.7 \text { to }+0.9)\end{array}$ & - & $\begin{array}{r}+1.3 \% \\
(-0.2 \text { to }+2.8)\end{array}$ & - \\
\hline
\end{tabular}

${ }^{a}$ Le Quéré et al. (2009). ${ }^{b}$ Friedlingstein et al. (2010). ${ }^{\mathrm{c}}$ Peters et al. (2013). ${ }^{\mathrm{d}}$ Le Quéré et al. (2013). ${ }^{\mathrm{e}}$ Le Quéré et al. (2014). ${ }^{\mathrm{f}}$ Friedlingstein et al. (2014) and Le Quéré et al. (2015b). ${ }^{\mathrm{g}}$ Jackson et al. (2016) and Le Quéré et al. (2015a). ${ }^{\mathrm{h}}$ This study. ${ }^{\mathrm{i}}$ These numbers are not adjusted for leap years (see Sect. 2.1.3 for leap-year adjustments).

emissions in 1990. The drivers of the trends in $E_{\mathrm{FF}}$ are discussed elsewhere (Peters et al., 2016).

For China, the expected change based on available data during January to July or September (see Sect. 2.1.4) is for an increase in emissions of $-0.2 \%$ (range of -3.5 to $+1.6 \%$ ) in 2016 compared to 2015 , or $-0.5 \%$ (range of -3.8 to $+1.3 \%$ ) after adjusting for leap year (see Sect. 2.1.3). This is based on estimated decreases in coal consumption $(-1.8 \%)$ and estimated growth in apparent oil $(+4.0 \%)$ and natural gas $(+7.2 \%)$ consumption and in cement production $(+2.6 \%)$. The uncertainty range considers the spread between different data sources, as well as differences between July/August and end-of-year data observed in 2014 and 2015. The estimated reduction in coal consumption also incorporates an assumed $2 \%$ increase in the energy density of coal - based on increases in the last 2 years, which are assumed to continue given production limits in 2016 that are likely to affect production of low-quality coal more - and the uncertainty range also reflects uncertainty in this figure.

For the USA, the EIA emissions projection for $2016 \mathrm{com}-$ bined with cement data from USGS gives a decrease of $-1.4 \%$ (range of -3.7 to $+0.9 \%$ ) compared to 2015 , or $-1.7 \%$ (range of -4.0 to $+0.6 \%$ ) after adjusting for leap year (see Sect. 2.1.3).

For the rest of the world, the expected growth for 2016 of $+1.3 \%$ (range of -0.2 to $+2.8 \%$ ), or $+1.0 \%$ (range of -0.4 to $+2.5 \%$ ) after adjusting for leap year (see Sect. 2.1.3). This is computed using the GDP projection for the world excluding China and the USA of $2.5 \%$ made by the IMF (IMF, 2016) and a decrease in $I_{\mathrm{FF}}$ of $-1.2 \% \mathrm{yr}^{-1}$, which is the average from 2006 to 2015 . The uncertainty range is based on the standard deviation of the interannual variability in $I_{\mathrm{FF}}$ during 2006-2015 of $\pm 1.0 \% \mathrm{yr}^{-1}$ and our estimate of uncertainty in the IMF's GDP forecast of $\pm 0.5 \%$.

\subsubsection{Partitioning among the atmosphere, ocean, and land}

The growth in atmospheric $\mathrm{CO}_{2}$ concentration $\left(G_{\mathrm{ATM}}\right)$ was projected to be high again in 2016, at $6.7 \pm 1.1 \mathrm{GtC}$ $(3.15 \pm 0.53 \mathrm{ppm})$ for the Mauna Loa station (Betts et al., 2016). Growth at Mauna Loa is closely correlated with the global growth ( $r=0.95$ for 1959-2015). Therefore, the global growth rate in atmospheric $\mathrm{CO}_{2}$ concentration is also expected to be high in 2016. In the 8-month period between December 2015 and August 2016, the observed global growth in atmospheric $\mathrm{CO}_{2}$ concentration was already 2.3 ppm (Dlugokencky and Tans, 2016) after seasonal adjustment, supporting the projection of Betts et al. (2016). Even with a return to El Niño neutral or possible emerging $\mathrm{La}$ Niña conditions for the second half of 2016, positive growth in atmospheric $\mathrm{CO}_{2}$ would still be expected during the last 
4 months of the year because of the continuing persistent emissions. For example, during the transitions from El Niño to La Niña of 1986-1987, 1998-1999, and 2010-2011, atmospheric $\mathrm{CO}_{2}$ growth of $0.3,0.6$, and $0.9 \mathrm{ppm}$, respectively, was observed in the last 4 months of the year.

Combining projected $E_{\mathrm{FF}}$ and $G_{\mathrm{ATM}}$ suggests a total for the combined land and ocean $\left(S_{\mathrm{LAND}}+S_{\text {OCEAN }}-E_{\mathrm{LUC}}\right)$ of about $3 \mathrm{GtC}$ only. $S_{\text {OCEAN }}$ was $3.0 \mathrm{GtC}$ in 2015 and is expected to slightly increase in 2016 from a delayed response to El Niño conditions (Feely et al., 1999). $E_{\mathrm{LUC}}$ was $1.3 \mathrm{GtC}$ in 2015 , above the decadal mean average of $1.0 \mathrm{GtC} \mathrm{yr}^{-1}$, and is expected to return to average or below average in 2016 based on fire activity related to land management so far (up to August). Hence, for 2016, the residual land sink $S_{\text {LAND }}$ is expected to be well below its 2006-2015 average and approximately balance $E_{\mathrm{LUC}}$. This is consistent with our understanding of the response of the terrestrial vegetation to $\mathrm{El}$ Niño conditions and increasing atmospheric $\mathrm{CO}_{2}$ concentrations, though the uncertainties in $G_{\mathrm{ATM}}$ and of the partitioning among $S_{\text {LAND }}$ and $S_{\text {OCEAN }}$ are substantial.

\subsection{Cumulative emissions}

Cumulative emissions for $1870-2015$ were $410 \pm 20 \mathrm{GtC}$ for $E_{\mathrm{FF}}$, and $145 \pm 50 \mathrm{GtC}$ for $E_{\mathrm{LUC}}$ based on the bookkeeping method of Houghton et al. (2012) for 1870-1996 and a combination with fire-based emissions for $1997-2015$ as described in Sect. 2.2 (Table 10). The cumulative emissions are rounded to the nearest $5 \mathrm{GtC}$. The total cumulative emissions from fossil and land-use change for 1870-2015 are $555 \pm 55 \mathrm{GtC}$. These emissions were partitioned among the atmosphere $(235 \pm 5 \mathrm{GtC}$ based on atmospheric measurements in ice cores of $288 \mathrm{ppm}$ (Sect. 2.3; Joos and Spahni, 2008) and recent direct measurements of $399.1 \mathrm{ppm}$ (Dlugokencky and Tans, 2016), ocean $(160 \pm 20 \mathrm{GtC}$ using Khatiwala et al. , 2013, prior to 1959 and Table 8 otherwise), and land ( $160 \pm 60 \mathrm{GtC}$ by the difference).

Cumulative emissions for the early period 1750-1869 were $3 \mathrm{GtC}$ for $E_{\mathrm{FF}}$ and about $45 \mathrm{GtC}$ for $E_{\mathrm{LUC}}$ (rounded to nearest 5), of which $10 \mathrm{GtC}$ was emitted in the period 1850 1870 (Houghton et al., 2012) and $30 \mathrm{GtC}$ in the period 17501850 based on the average of four publications ( $22 \mathrm{GtC}$ by Pongratz et al., 2009; $15 \mathrm{GtC}$ by van Minnen et al., 2009; 64 GtC by Shevliakova et al., 2009; and 24 GtC by Zaehle et al., 2011). The growth rate in atmospheric $\mathrm{CO}_{2}$ concentration during that time was about $25 \mathrm{GtC}$, and the ocean uptake about $20 \mathrm{GtC}$, implying a land uptake of $5 \mathrm{GtC}$. These numbers have large relative uncertainties but balance within the limits of our understanding.

Cumulative emissions for 1750-2015 based on the sum of the two periods above (before rounding to the nearest $5 \mathrm{GtC}$ ) were $410 \pm 20 \mathrm{GtC}$ for $E_{\mathrm{FF}}$, and $190 \pm 65 \mathrm{GtC}$ for $E_{\mathrm{LUC}}$, for a total of $600 \pm 70 \mathrm{GtC}$, partitioned among the atmosphere $(260 \pm 5 \mathrm{GtC})$, ocean $(175 \pm 20 \mathrm{GtC})$, and land $(165 \pm 70 \mathrm{GtC})$.
Cumulative emissions through to year 2016 can be estimated based on the 2016 projections of $E_{\mathrm{FF}}$ (Sect. 3.2), the largest contributor, and assuming a constant $E_{\mathrm{LUC}}$ of $1.0 \mathrm{GtC}$ (average of last decade). For 1870-2016, these are $565 \pm 55 \mathrm{GtC}\left(2075 \pm 205 \mathrm{GtCO}_{2}\right)$ for total emissions, with about $75 \%$ contribution from $E_{\mathrm{FF}}(420 \pm 20 \mathrm{GtC})$ and about $25 \%$ contribution from $E_{\mathrm{LUC}}(150 \pm 50 \mathrm{GtC})$. Cumulative emissions since year 1870 are higher than the emissions of 515 [445 to 585] GtC reported in the IPCC (Stocker et al., 2013) because they include an additional $55 \mathrm{GtC}$ from emissions in 2012-2016 (mostly from $E_{\mathrm{FF}}$ ). The uncertainty presented here $( \pm 1 \sigma)$ is smaller than the range of $90 \%$ used by IPCC, but both estimates overlap within their uncertainty ranges.

\section{Discussion}

Each year when the global carbon budget is published, each component for all previous years is updated to take into account corrections that are the result of further scrutiny and verification of the underlying data in the primary input data sets. The updates have generally been relatively small and focused on the most recent years, except for land-use change, where they are more significant but still generally within the provided uncertainty range (Fig. 9). The difficulty in accessing land-cover change data to estimate $E_{\mathrm{LUC}}$ is the key problem to providing continuous records of emissions in this sector. Current FAO estimates are based on statistics reported at the country level and are not spatially explicit. Advances in satellite recovery of land-cover change could help to keep track of land-use change through time (Achard et al., 2014; Harris et al., 2012). Revisions in $E_{\mathrm{LUC}}$ for the 2008/2009 budget were the result of the release of FAO 2010, which contained a major update to forest cover change for the period 2000-2005 and provided the data for the following 5 years to 2010 (Fig. 9b). The differences this year could be attributable to both the different data and the different methods. Comparison of global carbon budget components released annually by GCP since 2006 show that update differences were highest at $0.82 \mathrm{GtC} \mathrm{yr}^{-1}$ for the growth rate in atmospheric $\mathrm{CO}_{2}$ concentration (from a one-off correction back to year 1979), $0.24 \mathrm{GtC} \mathrm{yr}^{-1}$ for fossil fuels and industry, and $0.52 \mathrm{GtC} \mathrm{yr}^{-1}$ for the ocean $\mathrm{CO}_{2}$ sink (from a change from one to multiple models; Fig. 9d). The update for the residual land $\mathrm{CO}_{2}$ sink was also large (Fig. 9e), with a maximum value of $0.83 \mathrm{GtC} \mathrm{yr}^{-1}$, directly reflecting revisions in other terms of the budget.

Our capacity to constrain the global carbon budget can be evaluated by adding the five components of Eq. (1) using DGVM estimates for $S_{\text {LAND }}$, thus using largely independent estimates for each component (Fig. 10). This residual global budget represents all the carbon unaccounted currently. Figure 10 shows that the mean global residual is close to zero, and there is no trend over the entire time period. However, 
Table 10. Cumulative $\mathrm{CO}_{2}$ emissions for different time periods in gigatonnes of carbon (GtC). We also provide the 1850-2005 time period used in a number of model evaluation publications. All uncertainties are reported as $\pm 1 \sigma$. All values are rounded to the nearest $5 \mathrm{GtC}$ as in Stocker et al. (2013), reflecting the limits of our capacity to constrain cumulative estimates. Thus, some columns will not exactly balance because of rounding errors.

\begin{tabular}{lrrrr}
\hline Units of GtC & $1750-2015$ & $1850-2005$ & $1870-2015$ & $1870-2016$ \\
\hline Emissions & & & & \\
\hline Fossil fuels and industry $\left(E_{\mathrm{FF}}\right)$ & $410 \pm 20$ & $320 \pm 15$ & $410 \pm 20$ & $420 \pm 20^{*}$ \\
Land-use-change emissions $\left(E_{\mathrm{LUC}}\right)$ & $190 \pm 65$ & $150 \pm 55$ & $145 \pm 50$ & $150 \pm 50^{*}$ \\
Total emissions & $600 \pm 70$ & $470 \pm 55$ & $555 \pm 55$ & $565 \pm 55^{*}$ \\
\hline Partitioning & & & \\
\hline Growth rate in atmospheric $\mathrm{CO}_{2}$ concentration $\left(G_{\mathrm{ATM}}\right)$ & $260 \pm 5$ & $195 \pm 5$ & $235 \pm 5$ & \\
Ocean sink $\left(S_{\mathrm{OCEAN}}\right)$ & $175 \pm 20$ & $160 \pm 20$ & $160 \pm 20$ & \\
Residual terrestrial sink $\left(S_{\mathrm{LAND}}\right)$ & $165 \pm 70$ & $115 \pm 60$ & $160 \pm 60$ & \\
\hline
\end{tabular}

* The extension to year 2016 uses the emissions projections for fossil fuels and industry for 2016 (Sect. 3.2) and assumes a constant $E_{\mathrm{LUC}}$ flux (Sect. 2.2)

it also highlights periods of multiple years where the sum of the estimates differs significantly from zero. These include an unaccounted flux from the surface to the atmosphere (or underestimated emissions) during 1973-1979 and 1997-2001 and an unaccounted sink from the atmosphere to the surface (or overestimated emissions) during 1961-1965 and 19901992. This unaccounted variability could come from errors in our estimates of the five components of Equation $(1 ; \mathrm{Li}$ et al., 2016), or from missing factors in the global carbon budget, including but not limited to those discussed in Sect. 2.7. This unaccounted variability limits our ability to verify reported emissions and limits our confidence in the underlying processes regulating the carbon cycle feedbacks with climate change.

Another semi-independent way to evaluate the results is provided through the comparison with the atmospheric inversions and their regional breakdown. The comparison shows a first-order consistency between inversions and process models but with substantial discrepancies, particularly for the allocation of the mean sink between the tropics and the Northern Hemisphere. Understanding these discrepancies and further analysis of regional carbon budgets would provide additional information to quantify and improve our estimates, as has been shown by the project REgional Carbon Cycle Assessment and Processes (RECCAP; Canadell et al., 2012).

Annual estimates of each component of the global carbon budgets have their limitations, some of which could be improved with better data and/or better understanding of carbon dynamics. The primary limitations involve resolving fluxes on annual timescales and providing updated estimates for recent years for which data-based estimates are not yet available or only beginning to emerge. Of the various terms in the global budget, only the burning of fossil fuels and the growth rate in atmospheric $\mathrm{CO}_{2}$ concentration terms are based primarily on empirical inputs supporting annual estimates in this carbon budget. While these models represent the current state of the art, they provide only simulated changes in primary carbon budget components. For example, the decadal trends in global ocean uptake and the interannual variations associated with the El Niño-Southern Ocean Oscillation (ENSO) are not directly constrained by observations, although many of the processes controlling these trends are sufficiently well known that the model-based trends still have value as benchmarks for further validation. Data-based products for the ocean $\mathrm{CO}_{2}$ sink provide new ways to evaluate the model results, and could be used directly as data become more rapidly available and methods for creating such products improve. However, there are still large discrepancies among data-based estimates, in large part due to the lack of routine data sampling, which precludes their direct use for now (Rödenbeck et al., 2015). Estimates of land-use emissions and their year-to-year variability have even larger uncertainty, and much of the underlying data are not available as an annual update. Efforts are underway to work with annually available satellite area change data or FAO reported data in combination with fire data and modelling to provide annual updates for future budgets.

Our approach also depends on the reliability of the energy and land-cover change statistics provided at the country level, which are potentially subject to biases. Thus, it is critical to develop multiple ways to estimate the carbon balance at the global and regional level, including estimates from the inversion of atmospheric $\mathrm{CO}_{2}$ concentration, the use of other oceanic and atmospheric tracers, and the compilation of emissions using alternative statistics (e.g. sectors). It is also important to challenge the consistency of information across observational streams, for example to contrast the coherence of temperature trends with those of $\mathrm{CO}_{2}$ sink trends. Multiple approaches ranging from global to regional scale would greatly help increase confidence and reduce uncertainty in $\mathrm{CO}_{2}$ emissions and their fate. 

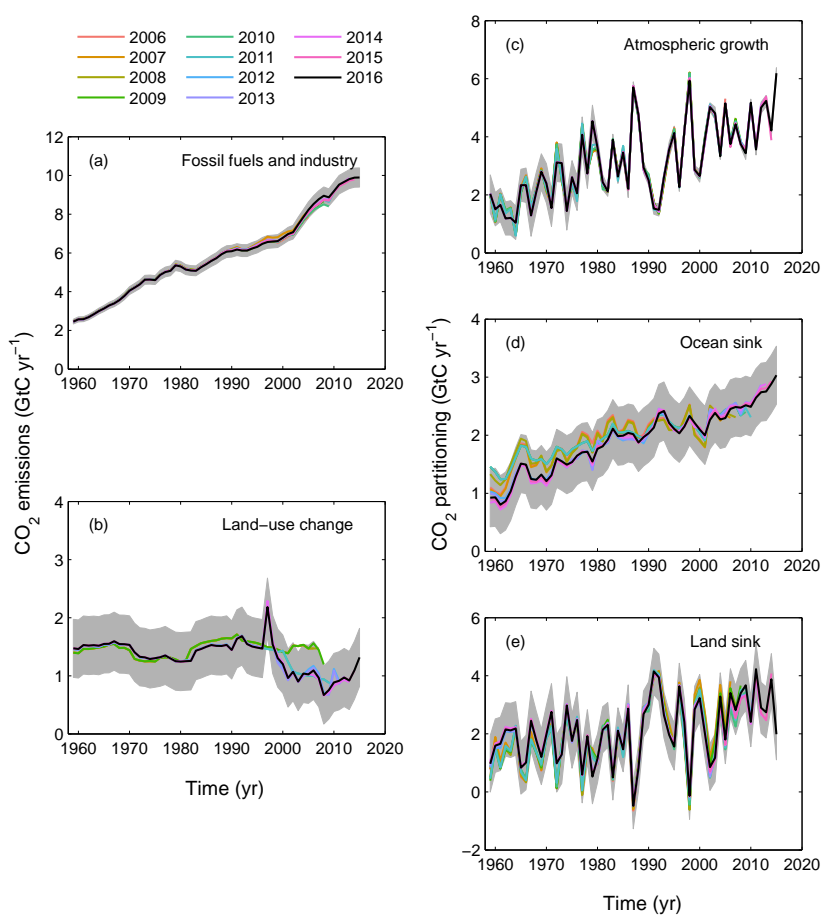

Figure 9. Comparison of global carbon budget components released annually by GCP since 2006. $\mathrm{CO}_{2}$ emissions from (a) fossil fuels and industry $\left(E_{\mathrm{FF}}\right)$ and $(\mathbf{b})$ land-use change $\left(E_{\mathrm{LUC}}\right)$, as well as their partitioning among $(\mathbf{c})$ the atmosphere $\left(G_{\text {ATM }}\right)$, (d) the ocean $\left(S_{\text {OCEAN }}\right)$, and (e) the land $\left(S_{\text {LAND }}\right)$. See legend for the corresponding years, and Table 3 for references. The budget year corresponds to the year when the budget was first released. All values

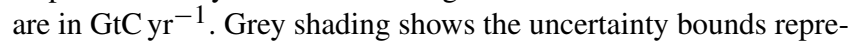
senting $\pm 1 \sigma$ of the current global carbon budget.

\section{Data availability}

The data presented here are made available in the belief that their wide dissemination will lead to greater understanding and new scientific insights into how the carbon cycle works, how humans are altering it, and how we can mitigate the resulting human-driven climate change. The free availability of these data does not constitute permission for publication of the data. For research projects, if the data are essential to the work, or if an important result or conclusion depends on the data, co-authorship may need to be considered. Full contact details and information on how to cite the data are given at the top of each page in the accompanying database and are summarised in Table 2.

The accompanying database includes two Excel files organised in the following spreadsheets (accessible with the free viewer http://www.microsoft.com/en-us/download/ details.aspx?id=10).

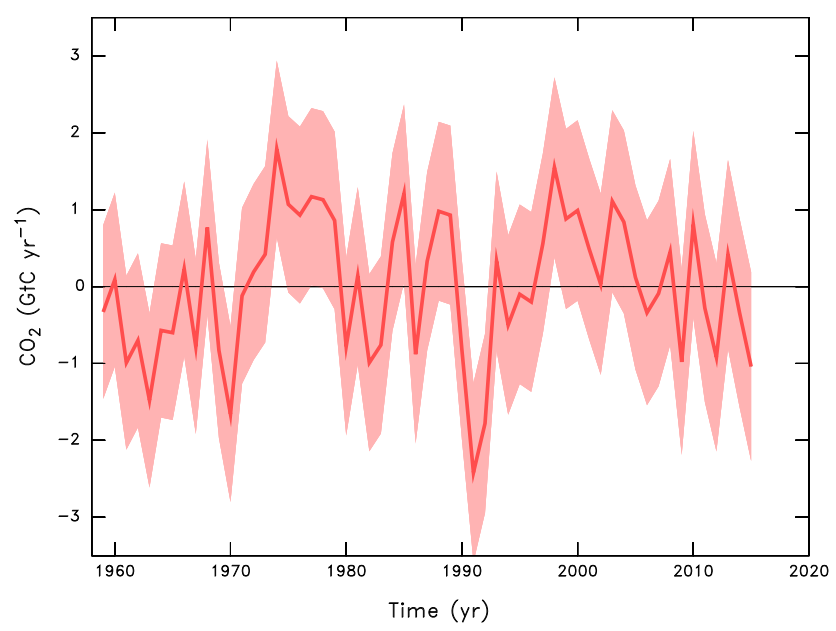

Figure 10. Unaccounted carbon in the global carbon budget

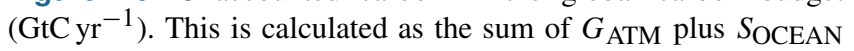
minus $E_{\mathrm{FF}}$ and $E_{\mathrm{LUC}}$ as described in Fig. 4 , plus $S_{\mathrm{LAND}}$ as estimated with the ensemble of DGVMs as in Fig. 6b. Therefore, the unaccounted carbon represents the fluxes that are missing after accounting for all known processes as quantified in available estimates (see discussion). The uncertainty is the annual uncertainty for the five terms as described in the text, added in quadrature. Positive values indicate an unaccounted surface-to-atmosphere flux of $\mathrm{CO}_{2}$ or an underestimation of the emissions.

File Global_Carbon_Budget_2016v1.0.xlsx includes the following:

\section{Summary}

2. The global carbon budget (1959-2015)

3. Global $\mathrm{CO}_{2}$ emissions from fossil fuels and cement production by fuel type, and the per capita emissions (1959-2015)

4. $\mathrm{CO}_{2}$ emissions from land-use change from the individual methods and models (1959-2015)

5. Ocean $\mathrm{CO}_{2}$ sink from the individual ocean models and data products (1959-2015)

6. Terrestrial residual $\mathrm{CO}_{2}$ sink from the DGVMs (19592015)

7. Additional information on the carbon balance prior to 1959 (1750-2015)

File National_Carbon_Emissions_2016v1.0.xlsx includes the following:

\section{Summary}

2. Territorial country $\mathrm{CO}_{2}$ emissions from fossil fuels and industry (1959-2015) from CDIAC, extended to 2015 using BP data 
3. Territorial country $\mathrm{CO}_{2}$ emissions from fossil fuels and industry (1959-2015) from CDIAC with UNFCCC data overwritten where available, extended to 2015 using BP data

4. Consumption country $\mathrm{CO}_{2}$ emissions from fossil fuels and industry and emissions transfer from the international trade of goods and services (1990-2014) using CDIAC/UNFCCC data (worksheet 3 above) as reference

5. Emissions transfers (consumption minus territorial emissions; 1990-2014)

6. Country definitions

7. Details of disaggregated countries

8. Details of aggregated countries

National emissions data are also available from the Global Carbon Atlas (http://globalcarbonatlas.org).

\section{Conclusions}

The estimation of global $\mathrm{CO}_{2}$ emissions and sinks is a major effort by the carbon cycle research community that requires a combination of measurements and compilation of statistical estimates and results from models. The delivery of an annual carbon budget serves two purposes. First, there is a large demand for up-to-date information on the state of the anthropogenic perturbation of the climate system and its underpinning causes. A broad stakeholder community relies on the data sets associated with the annual carbon budget, including scientists, policy makers, businesses, journalists, and the broader society increasingly engaged in adapting to and mit- igating human-driven climate change. Second, over the last decade we have seen unprecedented changes in the human and biophysical environments (e.g. increase in the growth of fossil fuel emissions, ocean temperatures, and strength of the land sink), which call for more frequent assessments of the state of the planet and, by implication, a better understanding of the future evolution of the carbon cycle. Both the ocean and the land surface presently remove a large fraction of anthropogenic emissions. Any significant change in the function of carbon sinks is of great importance to climate policymaking, as they affect the excess carbon dioxide remaining in the atmosphere and therefore the compatible emissions for any climate stabilisation target. Better constraints of carbon cycle models against contemporary data sets raise the capacity for the models to become more accurate at future projections.

This all requires more frequent, robust, and transparent data sets and methods that can be scrutinised and replicated. After 11 annual releases from the GCP, the effort is growing and the traceability of the methods has become increasingly complex. Here, we have documented in detail the data sets and methods used to compile the annual updates of the global carbon budget, explained the rationale for the choices made and the limitations of the information, and finally highlighted the need for additional information where gaps exist.

This paper via "living data" will help to keep track of new budget updates. The evolution over time of the carbon budget is now a key indicator of the anthropogenic perturbation of the climate system, and its annual delivery joins a set of other climate indicators to monitor the evolution of human-induced climate change, such as the annual updates on the global surface temperature, sea level rise, and minimum Arctic sea ice extent. 
Appendix A

Table A1. Attribution of $\mathrm{fCO}_{2}$ measurements for year 2015 included in addition to SOCAT v4 (Bakker et al., 2016) to inform ocean data products.

\begin{tabular}{|c|c|c|c|c|c|c|}
\hline Vessel & Start date yyyy-mm-dd & End date yyyy-mm-dd & Regions & No. of samples & Principal investigators & DOI (if available)/comment \\
\hline Atlantic Companion & 2015-03-03 & 2015-03-10 & North Atlantic & 8496 & $\begin{array}{l}\text { Steinhoff, } \quad \mathrm{T} . ; \\
\text { M.; Körtzinger, A. }\end{array}$ & doi:10.3334/CDIAC/OTG.VOS_Atlantic_Companion_Line_2015 \\
\hline Atlantic Companion & 2015-03-30 & 2015-04-07 & North Atlantic & 9265 & $\begin{array}{l}\text { Steinhoff, } \quad \text { T.; } \\
\text { M.; Körtzinger, A. }\end{array}$ & doi:10.3334/CDIAC/OTG.VOS_Atlantic_Companion_Line_2015 \\
\hline Aurora Australis & 2014-12-05 & 2015-01-24 & Southern Ocean & 41463 & Tilbrook, B. & doi:10.3334/CDIAC/OTG.VOS_AA_2014 \\
\hline Benguela Stream & 2015-01-08 & 2015-01-14 & $\begin{array}{l}\text { North Atlantic, } \\
\text { Tropical Atlantic }\end{array}$ & 4664 & $\frac{\overline{\text { Schuster, U.; }}}{\text { son, J.J. Jones, S.D.; Wat- }}$ & doi:10.3334/CDIAC/OTG.VOS_BENGUELA_STREAM_2015 \\
\hline Benguela Stream & 2015-02-05 & 2015-02-12 & $\begin{array}{l}\text { North Atlantic, } \\
\text { Tropical Atlantic }\end{array}$ & 4056 & $\frac{\text { Schuster, U.; Jones, S.D.; Wat- }}{\text { son, A.J. }}$ & doi:10.3334/CDIAC/OTG.VOS_BENGUELA_STREAM_2015 \\
\hline Benguela Stream & 2015-02-22 & 2015-03-01 & $\begin{array}{l}\text { North Atlantic, } \\
\text { Tropical Atlantic }\end{array}$ & 6158 & $\frac{\text { Schuster, U.; Jones, S.D.; Wat- }}{\text { son, A.J. }}$ & doi:10.3334/CDIAC/OTG.VOS_BENGUELA_STREAM_2015 \\
\hline Benguela Stream & 2015-04-30 & 2015-05-07 & $\begin{array}{l}\text { North Atlantic, } \\
\text { Tropical Atlantic }\end{array}$ & 6125 & $\frac{\text { Schuster, U.; Jones, S.D.; Wat- }}{\text { son, A.J. }}$ & doi:10.3334/CDIAC/OTG.VOS_BENGUELA_STREAM_2015 \\
\hline Benguela Stream & 2015-05-17 & 2015-05-24 & $\begin{array}{l}\text { North Atlantic, } \\
\text { Tropical Atlantic }\end{array}$ & 6152 & $\frac{\text { Schuster, U.; Jones, S.D.; Wat- }}{\text { son, A.J. }}$ & doi:10.3334/CDIAC/OTG.VOS_BENGUELA_STREAM_2015 \\
\hline Benguela Stream & 2015-05-27 & 2015-06-04 & $\begin{array}{l}\text { North Atlantic, } \\
\text { Tropical Atlantic }\end{array}$ & 6116 & $\frac{\text { Schuster, U.; Jones, S.D.; Wat- }}{\text { son, A.J. }}$ & doi:10.3334/CDIAC/OTG.VOS_BENGUELA_STREAM_2015 \\
\hline Benguela Stream & 2015-06-24 & 2015-07-02 & $\begin{array}{l}\text { North Atlantic, } \\
\text { Tropical Atlantic }\end{array}$ & 6538 & $\frac{\text { Schuster, U.; Jones, S.D.; Wat- }}{\text { son, A.J. }}$ & doi:10.3334/CDIAC/OTG.VOS_BENGUELA_STREAM_2015 \\
\hline Benguela Stream & 2015-07-11 & 2015-07-19 & $\begin{array}{l}\text { North Atlantic, } \\
\text { Tropical Atlantic }\end{array}$ & 6220 & $\frac{\text { Schuster, U.; Jones, S.D.; Wat- }}{\text { son, A.J. }}$ & doi:10.3334/CDIAC/OTG.VOS_BENGUELA_STREAM_2015 \\
\hline Benguela Stream & $2015-07-22$ & 2015-07-30 & $\begin{array}{l}\text { North Atlantic, } \\
\text { Tropical Atlantic }\end{array}$ & 6534 & $\frac{\text { Schuster, U.; Jones, S.D.; Wat- }}{\text { son, A.J. }}$ & doi:10.3334/CDIAC/OTG.VOS_BENGUELA_STREAM_2015 \\
\hline Benguela Stream & 2015-08-08 & 2015-08-16 & $\begin{array}{l}\text { North Atlantic, } \\
\text { Tropical Atlantic }\end{array}$ & 6727 & $\frac{\text { Schuster, U.; Jones, S.D.; Wat- }}{\text { son, A.J. }}$ & doi:10.3334/CDIAC/OTG.VOS_BENGUELA_STREAM_2015 \\
\hline Benguela Stream & 2015-08-19 & 2015-08-27 & $\begin{array}{l}\text { North Atlantic, } \\
\text { Tropical Atlantic }\end{array}$ & 6811 & $\frac{\text { Schuster, U.; Jones, S.D.; Wat- }}{\text { son, A.J. }}$ & doi:10.3334/CDIAC/OTG.VOS_BENGUELA_STREAM_2015 \\
\hline Cap Blanche & 2015-03-28 & 2015-04-10 & $\begin{array}{l}\text { Tropical Pacific, } \\
\text { Southern Ocean }\end{array}$ & 6117 & Cosca C.; Feely R.; Alin S. & doi:10.3334/CDIAC/OTG.VOS_CAP_BLANCHE_2015 \\
\hline Cap Blanche & 2015-09-30 & $2015-10-12$ & $\begin{array}{l}\text { Tropical Pacific, } \\
\text { Southern Ocean }\end{array}$ & 5582 & Cosca C.; Feely R.; Alin S. & doi:10.3334/CDIAC/OTG.VOS_CAP_BLANCHE_2015 \\
\hline Cap Blanche & 2015-11-20 & 2015-12-04 & $\begin{array}{l}\text { Tropical Pacific, } \\
\text { Southern Ocean }\end{array}$ & 6677 & Cosca C.; Feely R.; Alin S. & doi:10.3334/CDIAC/OTG.VOS_CAP_BLANCHE_2015 \\
\hline Cap San Lorenzo & $2015-02-28$ & 2015-03-12 & $\begin{array}{l}\text { North Atlantic, } \\
\text { Tropical Atlantic }\end{array}$ & 5699 & Lefèvre, N., Diverrès D. & \\
\hline Cap San Lorenzo & 2015-03-31 & 2015-04-06 & Tropical Atlantic & 2654 & Lefèvre, N., Diverrès D. & \\
\hline Cap San Lorenzo & 2015-04-28 & 2015-05-07 & $\begin{array}{l}\text { North Atlantic, } \\
\text { Tropical Atlantic }\end{array}$ & 4335 & Lefèvre, N., Diverrès D. & \\
\hline Cap San Lorenzo & 2015-06-20 & 2015-07-01 & $\begin{array}{l}\text { North Atlantic, } \\
\text { Tropical Atlantic }\end{array}$ & 5833 & Lefèvre, N., Diverrès D. & \\
\hline Cap San Lorenzo & 2015-07-29 & 2015-08-04 & North Atlantic & 2934 & Lefèvre, N., Diverrès D. & \\
\hline Colibri & $2015-02-26$ & 2015-03-10 & $\begin{array}{l}\text { North Atlantic, } \\
\text { Tropical Atlantic }\end{array}$ & 4615 & Lefèvre, N., Diverrès D. & \\
\hline Colibri & 2015-03-12 & 2015-03-23 & $\begin{array}{l}\text { North Atlantic, } \\
\text { Tropical Atlantic }\end{array}$ & 5561 & Lefèvre, N., Diverrès D. & \\
\hline Colibri & 2015-05-26 & 2015-06-04 & $\begin{array}{l}\text { North Atlantic, } \\
\text { Tropical Atlantic }\end{array}$ & 3683 & Lefèvre, N., Diverrès D. & \\
\hline Colibri & 2015-06-07 & 2015-06-18 & $\begin{array}{l}\text { North Atlantic, } \\
\text { Tropical Atlantic }\end{array}$ & 5613 & $\underline{\text { Lefèvre, N., Diverrès D. }}$ & \\
\hline Equinox & 2015-02-24 & 2015-03-06 & Tropical Atlantic & 3563 & $\begin{array}{l}\text { Wanninkhof, R.; Pierrot, D.; } \\
\text { Barbero, L. }\end{array}$ & doi:10.3334/CDIAC/OTG.VOS_EQNX_2015 \\
\hline Equinox & 2015-03-07 & 2015-03-11 & Tropical Atlantic & 1588 & $\begin{array}{l}\text { Wanninkhof, R.; Pierrot, D.; } \\
\text { Barbero, L. }\end{array}$ & doi:10.3334/CDIAC/OTG.VOS_EQNX_2015 \\
\hline Equinox & 2015-03-19 & 2015-03-27 & Tropical Atlantic & 2694 & $\begin{array}{l}\text { Wanninkhof, R.; Pierrot, D.; } \\
\text { Barbero, L. }\end{array}$ & doi:10.3334/CDIAC/OTG.VOS_EQNX_2015 \\
\hline Equinox & 2015-03-27 & 2015-04-06 & Tropical Atlantic & 3607 & $\begin{array}{l}\text { Wanninkhof, R.; Pierrot, D.; } \\
\text { Barbero, L. }\end{array}$ & doi:10.3334/CDIAC/OTG.VOS_EQNX_2015 \\
\hline Equinox & 2015-04-06 & 2015-04-17 & Tropical Atlantic & 3750 & $\begin{array}{l}\text { Wanninkhof, R.; Pierrot, D.; } \\
\text { Barbero, L. }\end{array}$ & doi:10.3334/CDIAC/OTG.VOS_EQNX_2015 \\
\hline Equinox & 2015-04-17 & 2015-04-27 & Tropical Atlantic & 3611 & $\begin{array}{l}\text { Wanninkhof, R.; Pierrot, D.; } \\
\text { Barbero, L. }\end{array}$ & doi:10.3334/CDIAC/OTG.VOS_EQNX_2015 \\
\hline Equinox & 2015-04-28 & 2015-05-11 & $\begin{array}{l}\text { North Atlantic, } \\
\text { Tropical Atlantic }\end{array}$ & 5151 & $\begin{array}{l}\overline{\text { Wanninkhof, }} \text { R.; Pierrot, D.; } \\
\text { Barbero, L. }\end{array}$ & doi:10.3334/CDIAC/OTG.VOS_EQNX_2015 \\
\hline Equinox & 2015-05-11 & 2015-05-21 & North Atlantic & 2323 & $\begin{array}{l}\text { Wanninkhof, R.; Pierrot, D.; } \\
\text { Barbero, L. }\end{array}$ & doi:10.3334/CDIAC/OTG.VOS_EQNX_2015 \\
\hline Equinox & 2015-05-21 & 2015-06-02 & North Atlantic & 3565 & $\begin{array}{l}\text { Wanninkhof, R.; Pierrot, D.; } \\
\text { Barbero, L. }\end{array}$ & doi:10.3334/CDIAC/OTG.VOS_EQNX_2015 \\
\hline Equinox & 2015-06-02 & 2015-06-04 & North Atlantic & 484 & $\begin{array}{l}\text { Wanninkhof, R.; Pierrot, D.; } \\
\text { Barbero, L. }\end{array}$ & doi:10.3334/CDIAC/OTG.VOS_EQNX_2015 \\
\hline Explorer of the Seas & 2014-12-27 & 2015-01-04 & Tropical Atlantic & 2804 & $\begin{array}{l}\text { Wanninkhof, R.; Pierrot, D.; } \\
\text { Barbero, L. }\end{array}$ & doi:10.3334/CDIAC/OTG.VOS_EXP2014 \\
\hline Explorer of the Seas & 2015-01-04 & 2015-01-09 & Tropical Atlantic & 1698 & $\begin{array}{l}\text { Wanninkhof, R.; Pierrot, D.; } \\
\text { Barbero, L. }\end{array}$ & doi:10.3334/CDIAC/OTG.VOS_EXP2015 \\
\hline Explorer of the Seas & 2015-01-09 & 2015-01-18 & Tropical Atlantic & 3176 & $\begin{array}{l}\text { Wanninkhof, R.; Pierrot, D.; } \\
\text { Barbero, L. }\end{array}$ & doi:10.3334/CDIAC/OTG.VOS_EXP2015 \\
\hline Explorer of the Seas & 2015-01-18 & 2015-01-24 & Tropical Atlantic & 2058 & $\begin{array}{l}\text { Wanninkhof, R.; Pierrot, D.; } \\
\text { Barbero, L. }\end{array}$ & doi:10.3334/CDIAC/OTG.VOS_EXP2015 \\
\hline Explorer of the Seas & 2015-01-24 & 2015-01-29 & Tropical Atlantic & 1587 & $\begin{array}{l}\text { Wanninkhof, R.; Pierrot, D.; } \\
\text { Barbero, L. }\end{array}$ & doi:10.3334/CDIAC/OTG.VOS_EXP2015 \\
\hline
\end{tabular}


Table A1. Continued.

\begin{tabular}{|c|c|c|c|c|c|c|}
\hline Vessel & Start date yyyy-mm-dd & End date yyyy-mm-dd & Regions & No. of samples & Principal investigators & DOI (if available)/comment \\
\hline Explorer of the Seas & 2015-01-29 & 2015-02-07 & Tropical Atlantic & 3176 & $\begin{array}{l}\text { Wanninkhof, R.; Pierrot, D.; } \\
\text { Barbero, L. }\end{array}$ & doi:10.3334/CDIAC/OTG.VOS_EXP2015 \\
\hline Explorer of the Seas & 2015-02-07 & $2015-02-12$ & Tropical Atlantic & 1707 & $\begin{array}{l}\text { Wanninkhof, R.; Pierrot, D.; } \\
\text { Barbero, L. }\end{array}$ & doi:10.3334/CDIAC/OTG.VOS_EXP2015 \\
\hline Explorer of the Seas & 2015-02-12 & 2015-02-15 & Tropical Atlantic & 1289 & $\begin{array}{l}\text { Wanninkhof, R.; Pierrot, D.; } \\
\text { Barbero, L. }\end{array}$ & doi:10.3334/CDIAC/OTG.VOS_EXP2015 \\
\hline F.G. Walton Smith & 2015-01-12 & 2015-01-14 & Tropical Atlantic & 816 & $\overline{\text { Millero, F.; Wanninkhof, R. }}$ & \\
\hline F.G. Walton Smith & 2015-04-09 & 2015-04-10 & Tropical Atlantic & 613 & Millero, F.; Wanninkhof, R. & \\
\hline F.G. Walton Smith & 2015-04-13 & 2015-04-17 & Tropical Atlantic & 2078 & Millero, F.; Wanninkhof, R. & \\
\hline F.G. Walton Smith & 2015-04-22 & 2015-05-02 & Tropical Atlantic & 3514 & Millero, F.; Wanninkhof, R. & \\
\hline F.G. Walton Smith & 2015-05-07 & 2015-05-20 & Tropical Atlantic & 6523 & Millero, F.; Wanninkhof, R. & \\
\hline F.G. Walton Smith & $2015-05-26$ & 2015-05-27 & Tropical Atlantic & 684 & Millero, F.; Wanninkhof, R. & \\
\hline F.G. Walton Smith & 2015-06-01 & 2015-06-05 & Tropical Atlantic & 2038 & Millero, F.; Wanninkhof, R. & \\
\hline F.G. Walton Smith & $2015-06-10$ & 2015-06-27 & Tropical Atlantic & 7319 & Millero, F.; Wanninkhof, R. & \\
\hline F.G. Walton Smith & 2015-07-14 & 2015-07-15 & Tropical Atlantic & 689 & Millero, F.; Wanninkhof, R. & \\
\hline F.G. Walton Smith & $2015-07-27$ & 2015-08-01 & Tropical Atlantic & 2258 & Millero, F.; Wanninkhof, R. & \\
\hline F.G. Walton Smith & $2015-08-22$ & 2015-09-04 & Tropical Atlantic & 6600 & Millero, F.; Wanninkhof, R. & \\
\hline F.G. Walton Smith & 2015-09-21 & 2015-09-25 & Tropical Atlantic & 2096 & Millero, F.; Wanninkhof, R. & \\
\hline F.G. Walton Smith & $2015-09-28$ & 2015-10-02 & Tropical Atlantic & 1990 & 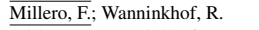 & \\
\hline F.G. Walton Smith & $2015-10-27$ & 2015-11-06 & $\begin{array}{l}\text { North Atlantic, } \\
\text { Tropical Atlantic }\end{array}$ & 3896 & 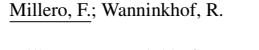 & \\
\hline F.G. Walton Smith & 2015-11-10 & 2015-11-11 & Tropical Atlantic & 271 & Millero, F.; Wanninkhof, R. & \\
\hline F.G. Walton Smith & 2015-11-16 & 2015-11-20 & Tropical Atlantic & 82 & Millero, F.; Wanninkhof, R. & \\
\hline G.O. Sars & 2015-01-17 & 2015-02-10 & North Atlantic & 9661 & $\overline{\text { Lauvset, S.K. }}$ & \\
\hline G.O. Sars & 2015-04-12 & 2015-04-25 & North Atlantic & 11719 & Lauvset, S.K.; Skjelvan, I. & \\
\hline G.O. Sars & 2015-04-29 & 2015-05-01 & North Atlantic & 2939 & Lauvset, S.K.; $\overline{\text { Skjelvan, I. }}$ & \\
\hline G.O. Sars & 2015-07-05 & 2015-07-14 & North Atlantic & 8921 & Lauvset, S.K.; $\overline{\text { Skjelvan, I. }}$ & \\
\hline G.O. Sars & $2015-07-21$ & 2015-08-13 & North Atlantic & 20088 & Lauvset, S.K.; $\overline{\text { Skjelvan, I. }}$ & \\
\hline G.O. Sars & 2015-08-18 & 2015-09-05 & North Atlantic & 18076 & Lauvset, S.K.; Skjelvan, I. & \\
\hline G.O. Sars & 2015-09-12 & 2015-09-25 & North Atlantic & 11327 & Lauvset, S.K.; Skjelvan, I. & \\
\hline G.O. Sars & $2015-09-30$ & 2015-10-14 & $\begin{array}{l}\text { Arctic, } \\
\text { North Atlantic }\end{array}$ & 13610 & Lauvset, S.K.; Skjelvan, I. & \\
\hline G.O. Sars & 2015-10-27 & 2015-11-03 & North Atlantic & 6937 & Lauvset, S.K.; Skjelvan, I. & \\
\hline Gordon Gunter & 2015-03-04 & 2015-03-14 & Tropical Atlantic & 4678 & $\begin{array}{l}\text { Wanninkhof, R.; Pierrot, D.; } \\
\text { Barbero, L. }\end{array}$ & doi:10.3334/CDIAC/OTG.COAST_GU2015_UW \\
\hline Gordon Gunter & 2015-03-18 & 2015-04-02 & Tropical Atlantic & 5015 & $\begin{array}{l}\text { Wanninkhof, R.; Pierrot, D.; } \\
\text { Barbero, L. }\end{array}$ & doi:10.3334/CDIAC/OTG.COAST_GU2015_UW \\
\hline Gordon Gunter & 2015-04-15 & 2015-04-27 & $\begin{array}{l}\text { North Atlantic, } \\
\text { Tropical Atlantic }\end{array}$ & 4334 & $\begin{array}{l}\text { Wanninkhof, R.; Pierrot, D.; } \\
\text { Barbero, L. }\end{array}$ & doi:10.3334/CDIAC/OTG.COAST_GU2015_UW \\
\hline Gordon Gunter & 2015-05-16 & 2015-06-05 & North Atlantic & 9118 & $\begin{array}{l}\text { Wanninkhof, R.; Pierrot, D.; } \\
\text { Barbero, L. }\end{array}$ & doi:10.3334/CDIAC/OTG.COAST_GU2015_UW \\
\hline Gordon Gunter & 2015-06-09 & 2015-06-12 & North Atlantic & 1031 & $\begin{array}{l}\text { Wanninkhof, R.; Pierrot, D.; } \\
\text { Barbero, L. }\end{array}$ & doi:10.3334/CDIAC/OTG.COAST_GU2015_UW \\
\hline Gordon Gunter & 2015-06-19 & 2015-07-03 & North Atlantic & 5688 & $\begin{array}{l}\text { Wanninkhof, R.; Pierrot, D.; } \\
\text { Barbero, L. }\end{array}$ & doi:10.3334/CDIAC/OTG.COAST_GU2015_UW \\
\hline Gordon Gunter & 2015-07-08 & 2015-07-24 & $\begin{array}{l}\text { North Atlantic, } \\
\text { Tropical Atlantic }\end{array}$ & 7293 & $\begin{array}{l}\text { Wanninkhof, R.; Pierrot, D.; } \\
\text { Barbero, L. }\end{array}$ & doi:10.3334/CDIAC/OTG.COAST_GU2015_UW \\
\hline Gordon Gunter & $2015-07-30$ & $2015-08-16$ & Tropical Atlantic & 7434 & $\begin{array}{l}\text { Wanninkhof, R.; Pierrot, D.; } \\
\text { Barbero, L. }\end{array}$ & doi:10.3334/CDIAC/OTG.COAST_GU2015_UW \\
\hline Gordon Gunter & $2015-08-23$ & 2015-09-06 & Tropical Atlantic & 6452 & $\begin{array}{l}\text { Wanninkhof, R.; Pierrot, D.; } \\
\text { Barbero, L. }\end{array}$ & doi:10.3334/CDIAC/OTG.COAST_GU2015_UW \\
\hline Gordon Gunter & 2015-09-14 & $2015-09-28$ & Tropical Atlantic & 6111 & $\begin{array}{l}\text { Wanninkhof, R.; Pierrot, D.; } \\
\text { Barbero, L. }\end{array}$ & doi:10.3334/CDIAC/OTG.COAST_GU2015_UW \\
\hline Gulf Challenger & $2015-03-13$ & 2015-03-13 & North Atlantic & 1148 & $\begin{array}{l}\text { Vandemark, D.; Salisbury, J.; } \\
\text { Hunt, C. }\end{array}$ & doi:10.3334/CDIAC/otg.TSM_UNH_GOM \\
\hline Gulf Challenger & 2015-06-05 & 2015-06-05 & North Atlantic & 1071 & $\begin{array}{l}\text { Vandemark, D.; Salisbury, J.; } \\
\text { Hunt, C. }\end{array}$ & doi:10.3334/CDIAC/otg.TSM_UNH_GOM \\
\hline Gulf Challenger & $2015-08-26$ & $2015-08-26$ & North Atlantic & 1127 & $\begin{array}{l}\text { Vandemark, D.; Salisbury, J.; } \\
\text { Hunt, C. }\end{array}$ & doi:10.3334/CDIAC/otg.TSM_UNH_GOM \\
\hline Gulf Challenger & 2015-10-07 & 2015-10-07 & North Atlantic & 1078 & $\begin{array}{l}\text { Vandemark, D.; Salisbury, J.; } \\
\text { Hunt, C. }\end{array}$ & doi:10.3334/CDIAC/otg.TSM_UNH_GOM \\
\hline Gulf Challenger & 2015-11-18 & 2015-11-18 & North Atlantic & 960 & $\begin{array}{l}\text { Vandemark, D.; Salisbury, J.; } \\
\text { Hunt, C. }\end{array}$ & doi:10.3334/CDIAC/otg.TSM_UNH_GOM \\
\hline Healy & 2015-07-14 & 2015-07-24 & $\begin{array}{l}\text { Arctic, } \\
\text { North Pacific }\end{array}$ & 4121 & $\begin{array}{l}\text { Sutherland, S.C.; Newberger, } \\
\text { T.; Takahashi, T. }\end{array}$ & doi:10.3334/CDIAC/OTG.VOS_Healy_Lines_2015 \\
\hline Healy & 2015-08-11 & $2015-10-21$ & $\begin{array}{l}\text { Arctic, } \\
\text { North Pacific }\end{array}$ & 27033 & $\begin{array}{l}\text { Sutherland, S.C.; Newberger, } \\
\text { T.; Takahashi, T. }\end{array}$ & doi:10.3334/CDIAC/OTG.VOS_Healy_Lines_2015 \\
\hline Healy & $2015-10-26$ & $2015-10-28$ & North Pacific & 960 & $\begin{array}{l}\text { Sutherland, S.C.; Newberger, } \\
\text { T.; Takahashi, T. }\end{array}$ & doi:10.3334/CDIAC/OTG.VOS_Healy_Lines_2015 \\
\hline Henry B. Bigelow & 2015-03-12 & 2015-03-21 & North Atlantic & 3525 & $\begin{array}{l}\text { Wanninkhof, R.; Pierrot, D.; } \\
\text { Barbero, L. }\end{array}$ & doi:10.3334/CDIAC/OTG.AOML_BIGELOW_ECOAST_2015 \\
\hline Henry B. Bigelow & $2015-03-23$ & 2015-04-03 & North Atlantic & 5059 & $\begin{array}{l}\text { Wanninkhof, R.; Pierrot, D.; } \\
\text { Barbero, L. }\end{array}$ & doi:10.3334/CDIAC/OTG.AOML_BIGELOW_ECOAST_2015 \\
\hline Henry B. Bigelow & 2015-04-07 & 2015-04-23 & North Atlantic & 6155 & $\begin{array}{l}\text { Wanninkhof, R.; Pierrot, D.; } \\
\text { Barbero, L. }\end{array}$ & doi:10.3334/CDIAC/OTG.AOML_BIGELOW_ECOAST_2015 \\
\hline Henry B. Bigelow & 2015-04-27 & 2015-05-07 & North Atlantic & 4638 & $\begin{array}{l}\text { Wanninkhof, R.; Pierrot, D.; } \\
\text { Barbero, L. }\end{array}$ & doi:10.3334/CDIAC/OTG.AOML_BIGELOW_ECOAST_2015 \\
\hline Henry B. Bigelow & 2015-05-19 & 2015-06-03 & North Atlantic & 6456 & $\begin{array}{l}\text { Wanninkhof, R.; Pierrot, D.; } \\
\text { Barbero, L. }\end{array}$ & doi:10.3334/CDIAC/OTG.AOML_BIGELOW_ECOAST_2015 \\
\hline Henry B. Bigelow & 2015-06-11 & 2015-06-19 & North Atlantic & 3839 & $\begin{array}{l}\text { Wanninkhof, R.; Pierrot, D.; } \\
\text { Barbero, L. }\end{array}$ & doi:10.3334/CDIAC/OTG.AOML_BIGELOW_ECOAST_2015 \\
\hline Henry B. Bigelow & $2015-06-24$ & 2015-07-02 & North Atlantic & 3401 & $\begin{array}{l}\text { Wanninkhof, R.; Pierrot, D.; } \\
\text { Barbero, L. }\end{array}$ & doi:10.3334/CDIAC/OTG.AOML_BIGELOW_ECOAST_2015 \\
\hline Henry B. Bigelow & $2015-07-27$ & 2015-08-07 & North Atlantic & 5265 & $\begin{array}{l}\text { Wanninkhof, R.; Pierrot, D.; } \\
\text { Barbero, L. }\end{array}$ & doi:10.3334/CDIAC/OTG.AOML_BIGELOW_ECOAST_2015 \\
\hline
\end{tabular}


Table A1. Continued.

\begin{tabular}{|c|c|c|c|c|c|c|}
\hline Vessel & Start date yyyy-mm-dd & End date yyyy-mm-dd & Regions & No. of samples & Principal investigators & DOI (if available)/comment \\
\hline Henry B. Bigelow & 2015-08-12 & $2015-08-21$ & North Atlantic & 4315 & $\begin{array}{l}\text { Wanninkhof, R.; Pierrot, D.; } \\
\text { Barbero, L. }\end{array}$ & doi:10.3334/CDIAC/OTG.AOML_BIGELOW_ECOAST_2015 \\
\hline Henry B. Bigelow & 2015-09-01 & $2015-09-17$ & North Atlantic & 7836 & $\begin{array}{l}\text { Wanninkhof, } \quad \text { R.; Pierrot, D.; } \\
\text { Barbero, L. }\end{array}$ & doi:10.3334/CDIAC/OTG.AOML_BIGELOW_ECOAST_2015 \\
\hline Henry B. Bigelow & $2015-09-23$ & 2015-09-30 & North Atlantic & 3382 & $\begin{array}{l}\text { Wanninkhof, } \quad \text { R.; Pierrot, D.; } \\
\text { Barbero, L. }\end{array}$ & doi:10.3334/CDIAC/OTG.AOML_BIGELOW_ECOAST_2015 \\
\hline Henry B. Bigelow & 2015-10-07 & $2015-10-22$ & North Atlantic & 7186 & $\begin{array}{l}\text { Wanninkhof, } \quad \text { R.; Pierrot, D.; } \\
\text { Barbero, L. }\end{array}$ & doi:10.3334/CDIAC/OTG.AOML_BIGELOW_ECOAST_2015 \\
\hline Henry B. Bigelow & 2015-10-27 & 2015-11-06 & North Atlantic & 4472 & $\begin{array}{l}\text { Wanninkhof, } \quad \text { R.; Pierrot, D.; } \\
\text { Barbero, L. }\end{array}$ & doi:10.3334/CDIAC/OTG.AOML_BIGELOW_ECOAST_2015 \\
\hline Henry B. Bigelow & 2015-11-12 & 2015-11-17 & North Atlantic & 2402 & $\begin{array}{l}\text { Wanninkhof, } \quad \text { R.; Pierrot, D.; } \\
\text { Barbero, L. }\end{array}$ & doi:10.3334/CDIAC/OTG.AOML_BIGELOW_ECOAST_2015 \\
\hline Laurence M. Gould & 2014-12-30 & 2015-02-07 & Southern Ocean & 7302 & $\begin{array}{l}\text { Sweeney, C.; Takahashi, T.; } \\
\text { Newberger, T.; Sutherland, } \\
\text { S.C.; Munro, D.R. }\end{array}$ & doi:10.3334/CDIAC/OTG.VOS_LM_GOULD_2014 \\
\hline Laurence M. Gould & 2015-02-14 & 2015-03-16 & Southern Ocean & 9450 & $\begin{array}{l}\text { Sweeney, C.; Takahashi, T.; } \\
\text { Newberger, T.; Sutherland, } \\
\text { S.C.; Munro, D.R. }\end{array}$ & doi:10.3334/CDIAC/OTG.VOS_LM_GOULD_2015 \\
\hline Laurence M. Gould & 2015-03-21 & 2015-04-03 & Southern Ocean & 2602 & $\begin{array}{l}\text { Sweeney, C.; Takahashi, T.; } \\
\text { Newberger, T.; Sutherland, } \\
\text { S.C.; Munro, D.R. }\end{array}$ & doi:10.3334/CDIAC/OTG.VOS_LM_GOULD_2015 \\
\hline Laurence M. Gould & 2015-04-08 & 2015-05-11 & Southern Ocean & 7691 & $\begin{array}{l}\text { Sweeney, C.; Takahashi, T.; } \\
\text { Newberger, T.; Sutherland, } \\
\text { S.C.; Munro, D.R. }\end{array}$ & doi:10.3334/CDIAC/OTG.VOS_LM_GOULD_2015 \\
\hline Laurence M. Gould & 2015-05-16 & 2015-06-16 & Southern Ocean & 9497 & $\begin{array}{l}\text { Sweeney, C.; Takahashi, T.; } \\
\text { Newberger, T.; Sutherland, } \\
\text { S.C.; Munro, D.R. }\end{array}$ & doi:10.3334/CDIAC/OTG.VOS_LM_GOULD_2015 \\
\hline Laurence M. Gould & 2015-06-21 & 2015-06-30 & Southern Ocean & 2379 & $\begin{array}{l}\text { Sweeney, C.; Takahashi, T.; } \\
\text { Newberger, T.; Sutherland, } \\
\text { S.C.; Munro, D.R. }\end{array}$ & doi:10.3334/CDIAC/OTG.VOS_LM_GOULD_2015 \\
\hline Marcus G. Langseth & 2015-04-13 & 2015-04-22 & North Atlantic & 1948 & $\begin{array}{l}\text { Sutherland, S.C.; Newberger, } \\
\text { T.; Takahashi, T.; Sweeney, C. }\end{array}$ & doi:10.3334/CDIAC/OTG.VOS_MG_LANGSETH_LINES_2015 \\
\hline Marcus G. Langseth & 2015-06-01 & $2015-06-23$ & North Atlantic & 8608 & $\begin{array}{l}\text { Sutherland, S.C.; Newberger, } \\
\text { T.; Takahashi, T.; Sweeney, C. }\end{array}$ & doi:10.3334/CDIAC/OTG.VOS_MG_LANGSETH_LINES_2015 \\
\hline Marcus G. Langseth & 2015-07-31 & 2015-09-12 & North Atlantic & 14519 & $\begin{array}{l}\text { Sutherland, S.C.; Newberger, } \\
\text { T.; Takahashi, T.; Sweeney, C. }\end{array}$ & doi:10.3334/CDIAC/OTG.VOS_MG_LANGSETH_LINES_2015 \\
\hline Marion Dufresne & 2015-01-07 & 2015-02-06 & $\begin{array}{l}\text { Indian Ocean, South- } \\
\text { ern Ocean }\end{array}$ & 4529 & Metzl, N.; Lo Monaco, C. & doi:10.3334/CDIAC/OTG.VOS_OISO_24 \\
\hline Mooring & 2014-03-07 & 2015-03-22 & Tropical Atlantic & 3048 & $\begin{array}{l}\text { Sutton, A.; Sabine, C.; } \\
\text { Manzello, D.; Musielewicz, S.; } \\
\text { Maenner, S.; Dietrich, C.; Bott, } \\
\text { R.; Osborne, J. }\end{array}$ & doi:10.3334/CDIAC/OTG.CHEECA_80W_25N \\
\hline Mooring & 2014-03-07 & 2015-04-03 & Tropical Pacific & 3129 & $\begin{array}{l}\text { Sutton, A.; Sabine, C.; Maen- } \\
\text { ner, S.; Musielewicz, S.; Bott, } \\
\text { R.; Osborne, J. }\end{array}$ & doi:10.3334/CDIAC/otg.TSM_Stratus_85W_20S \\
\hline Mooring & 2014-05-02 & 2015-04-28 & North Pacific & 2630 & $\begin{array}{l}\text { Sutton, A.; Sabine, C.; Send, } \\
\text { U.; Ohman, M.; Musielewicz, } \\
\text { S.; Maenner, S.; Dietrich, C.; } \\
\text { Bott, R.; Osborne, J. }\end{array}$ & doi:10.3334/CDIAC/OTG.TSM_CCE2_121W_34N \\
\hline Mooring & 2014-05-06 & $2015-01-27$ & North Pacific & 2122 & $\begin{array}{l}\text { Mathis, J.; Monacci, N.; } \\
\text { Musielewicz, S.; Maenner, S. }\end{array}$ & doi:10.3334/CDIAC/OTG.TSM_Southeast_AK_56N_134W \\
\hline Mooring & 2014-05-24 & 2015-05-06 & Tropical Pacific & 2447 & $\begin{array}{l}\text { Sutton, A.; Sabine, C.; } \quad \text { De } \\
\text { Carlo, E.; Musielewicz, S.; } \\
\text { Maenner, S.; Dietrich, C.; Bott, } \\
\text { R.; Osborne, J. }\end{array}$ & doi:10.3334/CDIAC/OTG.TSM_Kaneohe_158W_21N \\
\hline Mooring & 2014-07-21 & 2015-07-07 & North Atlantic & 2796 & $\begin{array}{l}\text { Sutton, A.; Sabine, C.; } \\
\text { dersson, An- } \\
\text { Musielewicz, } \quad \text { B.; } \quad \text { Maenner, } \\
\text { S.; Dietrich, C.; Bott, R.; } \\
\text { Osborne, J. }\end{array}$ & doi:10.3334/CDIAC/OTG.TSM_Crescent_64W_32N \\
\hline Mooring & 2014-10-06 & 2015-01-07 & North Atlantic & 741 & $\begin{array}{l}\text { Sutton, A.; Sabine, C.; Maen- } \\
\text { ner, S.; Musielewicz, S.; Bott, } \\
\text { R.; Osborne, J. }\end{array}$ & doi:10.3334/CDIAC/OTG.TSM_Hog_Reef_64W_32N \\
\hline Nathaniel B. Palmer & 2015-01-06 & 2015-01-18 & Southern Ocean & 4320 & $\begin{array}{l}\text { Sutherland, S.C.; Newberger, } \\
\text { T.; Takahashi, T.; Sweeney, C. }\end{array}$ & doi:10.3334/CDIAC/OTG.VOS_PALMER_2015 \\
\hline Nathaniel B. Palmer & $2015-01-23$ & 2015-03-14 & Southern Ocean & 17383 & $\begin{array}{l}\text { Sutherland, S.C.; Newberger, } \\
\text { T.; Takahashi, T.; Sweeney, C. }\end{array}$ & doi:10.3334/CDIAC/OTG.VOS_PALMER_2015 \\
\hline Nathaniel B. Palmer & 2015-03-27 & 2015-04-28 & Southern Ocean & 10623 & $\begin{array}{l}\text { Sutherland, S.C.; Newberger, } \\
\text { T.; Takahashi, T.; Sweeney, C. }\end{array}$ & doi:10.3334/CDIAC/OTG.VOS_PALMER_2015 \\
\hline Nathaniel B. Palmer & 2015-05-12 & $2015-05-28$ & Southern Ocean & 5654 & $\begin{array}{l}\text { Sutherland, S.C.; Newberger, } \\
\text { T.; Takahashi, T.; Sweeney, C. }\end{array}$ & doi:10.3334/CDIAC/OTG.VOS_PALMER_2015 \\
\hline Nathaniel B. Palmer & 2015-08-05 & $2015-08-28$ & Southern Ocean & 7528 & $\begin{array}{l}\text { Sutherland, S.C.; Newberger, } \\
\text { T.; Takahashi, T.; Sweeney, C. }\end{array}$ & doi:10.3334/CDIAC/OTG.VOS_PALMER_2015 \\
\hline Nathaniel B. Palmer & 2015-09-08 & 2015-10-18 & $\begin{array}{l}\text { Southern Ocean, } \\
\text { Tropical Atlantic }\end{array}$ & 13871 & $\begin{array}{l}\text { Sutherland, S.C.; Newberger, } \\
\text { T.; Takahashi, T.; Sweeney, C. }\end{array}$ & doi:10.3334/CDIAC/OTG.VOS_PALMER_2015 \\
\hline New Century 2 & 2014-12-12 & 2015-01-12 & $\begin{array}{l}\text { North Pacific, } \\
\text { Tropical Pacific }\end{array}$ & 3221 & Nakaoka, S. & doi:10.3334/CDIAC/OTG.VOS_New_Century_2_2014 \\
\hline New Century 2 & 2015-03-16 & 2015-03-31 & North Pacific & 1343 & Nakaoka, S. & doi:10.3334/CDIAC/OTG.VOS_New_Century_2_2015 \\
\hline New Century 2 & 2015-04-01 & 2015-04-14 & North Pacific & 1417 & Nakaoka, S. & doi:10.3334/CDIAC/OTG.VOS_New_Century_2_2015 \\
\hline New Century 2 & 2015-04-16 & 2015-05-03 & North Pacific & 1668 & Nakaoka, S. & doi:10.3334/CDIAC/OTG.VOS_New_Century_2_2015 \\
\hline New Century 2 & 2015-05-04 & 2015-05-17 & North Pacific & 1616 & Nakaoka, S. & doi:10.3334/CDIAC/OTG.VOS_New_Century_2_2015 \\
\hline New Century 2 & 2015-05-20 & 2015-06-04 & North Pacific & 1569 & Nakaoka, S. & doi:10.3334/CDIAC/OTG.VOS_New_Century_2_2015 \\
\hline
\end{tabular}


Table A1. Continued.

\begin{tabular}{|c|c|c|c|c|c|c|}
\hline Vessel & Start date yyyy-mm-dd & End date yyyy-mm-dd & Regions & No. of samples & Principal investigators & DOI (if available)/comment \\
\hline New Century 2 & 2015-06-05 & 2015-06-21 & North Pacific & 1545 & Nakaoka, S. & doi:10.3334/CDIAC/OTG.VOS_New_Century_2_2015 \\
\hline New Century 2 & 2015-06-23 & 2015-07-07 & North Pacific & 1376 & $\overline{\text { Nakaoka, } \mathrm{S} \text {. }}$ & doi:10.3334/CDIAC/OTG.VOS_New_Century_2_2015 \\
\hline New Century 2 & 2015-07-07 & 2015-07-20 & North Pacific & 1440 & $\overline{\text { Nakaoka, } \mathrm{S} \text {. }}$ & doi:10.3334/CDIAC/OTG.VOS_New_Century_2_2015 \\
\hline New Century 2 & 2015-07-23 & 2015-08-07 & North Pacific & 1538 & $\overline{\text { Nakaoka, } \mathrm{S} \text {. }}$ & doi:10.3334/CDIAC/OTG.VOS_New_Century_2_2015 \\
\hline New Century 2 & 2015-08-09 & 2015-08-21 & North Pacific & 1460 & $\overline{\text { Nakaoka, } \mathrm{S} \text {. }}$ & doi:10.3334/CDIAC/OTG.VOS_New_Century_2_2015 \\
\hline New Century 2 & $2015-08-26$ & $2015-09-24$ & $\begin{array}{l}\text { North Pacific, } \\
\text { Tropical Pacific }\end{array}$ & 2422 & Nakaoka, S. & doi:10.3334/CDIAC/OTG.VOS_New_Century_2_2015 \\
\hline New Century 2 & 2015-09-24 & $2015-10-23$ & $\begin{array}{l}\text { North Atlantic, North } \\
\text { Pacific, Tropical At- } \\
\text { lantic, Tropical Pa- } \\
\text { cific }\end{array}$ & 3157 & Nakaoka, S. & doi:10.3334/CDIAC/OTG.VOS_New_Century_2_2015 \\
\hline Nuka Arctica & $2015-10-21$ & 2015-11-08 & North Atlantic & 5318 & $\frac{\text { Omar, A.; }}{\text { nessen, T. }}$ Olsen, A.; Johan- & \\
\hline Nuka Arctica & 2015-12-01 & $2015-12-21$ & North Atlantic & 10558 & $\frac{\text { Omar, A.; }}{\text { nessen, T. }}$ Olsen, A.; Johan- & \\
\hline Polarstern & 2014-12-03 & 2015-01-31 & Southern Ocean & 58046 & van Heuven, S.; Hoppema, M. & doi:10.3334/CDIAC/OTG.OA_VOS_POLARSTERN_2014 \\
\hline Polarstern & 2015-05-19 & $2015-06-27$ & $\begin{array}{l}\text { Arctic, } \\
\text { North Atlantic }\end{array}$ & 39056 & van Heuven, S.; $\overline{\text { Hoppema, M. }}$ & doi:10.3334/CDIAC/OTG.OA_VOS_POLARSTERN_2015 \\
\hline Polarstern & $2015-06-29$ & 2015-08-14 & $\begin{array}{l}\text { Arctic, } \\
\text { North Atlantic }\end{array}$ & 20164 & van Heuven, S.; Hoppema, M. & doi:10.3334/CDIAC/OTG.OA_VOS_POLARSTERN_2015 \\
\hline Polarstern & 2015-08-18 & 2015-10-11 & $\begin{array}{l}\text { Arctic, } \\
\text { North Atlantic }\end{array}$ & 43709 & van Heuven, S.; Hoppema, M. & doi:10.3334/CDIAC/OTG.OA_VOS_POLARSTERN_2015 \\
\hline Polarstern & $2015-10-30$ & 2015-12-01 & $\begin{array}{l}\text { North Atlantic, } \\
\text { Southern Ocean, } \\
\text { Tropical Atlantic }\end{array}$ & 27178 & van Heuven, S.; Hoppema, M. & doi:10.3334/CDIAC/OTG.OA_VOS_POLARSTERN_2015 \\
\hline Ronald H. Brown & 2015-01-15 & 2015-01-29 & $\begin{array}{l}\text { North Pacific, } \\
\text { Tropical Pacific }\end{array}$ & 4855 & $\begin{array}{l}\text { Wanninkhof, R.; Pierrot, D.; } \\
\text { Barbero, L. }\end{array}$ & doi:10.3334/CDIAC/OTG.VOS_RB_2015 \\
\hline Ronald H. Brown & 2015-01-30 & 2015-02-12 & North Pacific & 5365 & $\begin{array}{l}\text { Wanninkhof, } \quad \text { R.; Pierrot, D.; } \\
\text { Barbero, L. }\end{array}$ & doi:10.3334/CDIAC/OTG.VOS_RB_2015 \\
\hline Ronald H. Brown & 2015-03-01 & 2015-03-30 & Tropical Pacific & 13576 & $\begin{array}{l}\text { Wanninkhof, } \quad \text { R.; Pierrot, D.; } \\
\text { Barbero, L. }\end{array}$ & doi:10.3334/CDIAC/OTG.VOS_RB_2015 \\
\hline Ronald H. Brown & 2015-04-10 & 2015-05-12 & Tropical Pacific & 15021 & $\begin{array}{l}\text { Wanninkhof, } \quad \text { R.; Pierrot, D.; } \\
\text { Barbero, L. }\end{array}$ & doi:10.3334/CDIAC/OTG.VOS_RB_2015 \\
\hline Ronald H. Brown & $2015-05-25$ & 2015-06-24 & $\begin{array}{l}\text { North Pacific, } \\
\text { Tropical Pacific }\end{array}$ & 13690 & $\begin{array}{l}\text { Wanninkhof, } \quad \text { R.; Pierrot, D.; } \\
\text { Barbero, L. }\end{array}$ & doi:10.3334/CDIAC/OTG.VOS_RB_2015 \\
\hline Ronald H. Brown & 2015-07-14 & 2015-07-31 & North Pacific & 5862 & $\begin{array}{l}\text { Wanninkhof, } \quad \text { R.; Pierrot, D.; } \\
\text { Barbero, L. }\end{array}$ & doi:10.3334/CDIAC/OTG.VOS_RB_2015 \\
\hline Ronald H. Brown & 2015-08-06 & 2015-08-21 & $\begin{array}{l}\text { Arctic, } \\
\text { North Pacific }\end{array}$ & 6365 & $\begin{array}{l}\text { Wanninkhof, } \quad \text { R.; Pierrot, D.; } \\
\text { Barbero, L. }\end{array}$ & doi:10.3334/CDIAC/OTG.VOS_RB_2015 \\
\hline Ronald H. Brown & 2015-08-22 & 2015-09-04 & $\begin{array}{l}\text { Arctic, } \\
\text { North Pacific }\end{array}$ & 6298 & $\begin{array}{l}\text { Wanninkhof, } \quad \text { R.; Pierrot, D.; } \\
\text { Barbero, L. }\end{array}$ & doi:10.3334/CDIAC/OTG.VOS_RB_2015 \\
\hline Ronald H. Brown & 2015-11-22 & $2015-12-18$ & Tropical Pacific & 10838 & $\begin{array}{l}\text { Wanninkhof, } \quad \text { R.; Pierrot, D.; } \\
\text { Barbero, L. }\end{array}$ & doi:10.3334/CDIAC/OTG.VOS_RB_2015 \\
\hline S.A. Agulhas II & 2014-12-08 & 2015-02-16 & Southern Ocean & 23342 & $\begin{array}{l}\text { Monteiro, P.M.S.; } \\
\text { W.R.; Gregor, L. }\end{array}$ & doi:10.3334/CDIAC/OTG.VOS_SA_Agulhas_II_2015 \\
\hline S.A. Agulhas II & $2015-07-23$ & 2015-08-12 & Southern Ocean & 16271 & $\begin{array}{l}\text { Monteiro, P.M.S.; } \quad \text { Joubert, } \\
\text { W.R.; Gregor, L. }\end{array}$ & doi:10.3334/CDIAC/OTG.VOS_SA_Agulhas_II_2015 \\
\hline S.A. Agulhas II & 2015-09-04 & $2015-10-06$ & Southern Ocean & 12371 & $\begin{array}{l}\text { Monteiro, P.M.S.; } \\
\text { W.R.; Gregor, L. }\end{array}$ & doi:10.3334/CDIAC/OTG.VOS_SA_Agulhas_II_2015 \\
\hline Simon Stevin & 2015-06-01 & 2015-06-01 & North Atlantic & 445 & Gkritzalis, T.; Cattrijsse, A. & \\
\hline Simon Stevin & 2015-06-04 & 2015-06-04 & North Atlantic & 909 & Gkritzalis, T.; Cattrijsse, A. & \\
\hline Simon Stevin & 2015-06-08 & 2015-06-08 & North Atlantic & 440 & 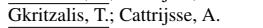 & \\
\hline Simon Stevin & $2015-06-23$ & 2015-06-23 & North Atlantic & 749 & $\overline{\text { Gkritzalis, T.; Cattrijsse, A. }}$ & \\
\hline Simon Stevin & 2015-06-24 & 2015-06-24 & North Atlantic & 1234 & Gkritzalis, T.; Cattrijsse, A. & \\
\hline Simon Stevin & $2015-06-25$ & 2015-06-25 & North Atlantic & 787 & 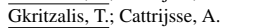 & \\
\hline Simon Stevin & $2015-06-30$ & 2015-06-30 & North Atlantic & 425 & 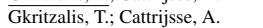 & \\
\hline Simon Stevin & 2015-07-02 & 2015-07-02 & North Atlantic & 154 & $\overline{\text { Gkritzalis, T.; }}$ Cattrijsse, A. & \\
\hline Simon Stevin & 2015-07-06 & 2015-07-06 & North Atlantic & 168 & 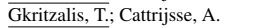 & \\
\hline Simon Stevin & 2015-07-10 & 2015-07-10 & North Atlantic & 357 & 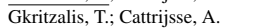 & \\
\hline Simon Stevin & 2015-07-13 & 2015-07-13 & North Atlantic & 223 & $\overline{\text { Gkritzalis, T.; }}$ Cattrijsse, A. & \\
\hline Simon Stevin & 2015-07-14 & 2015-07-14 & North Atlantic & 54 & 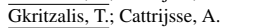 & \\
\hline Simon Stevin & 2015-07-15 & $2015-07-15$ & North Atlantic & 477 & 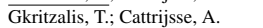 & \\
\hline Simon Stevin & 2015-07-16 & 2015-07-16 & North Atlantic & 465 & $\overline{\text { Gkritzalis, T.; }}$ Cattrijsse, A. & \\
\hline Simon Stevin & 2015-07-22 & 2015-07-22 & North Atlantic & 87 & 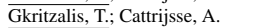 & \\
\hline Simon Stevin & $2015-07-23$ & $2015-07-23$ & North Atlantic & 428 & Gkritzalis, T.; Cattrijsse, A. & \\
\hline Simon Stevin & 2015-07-24 & 2015-07-24 & North Atlantic & 299 & $\overline{\text { Gkritzalis, T.; }}$ Cattrijsse, A. & \\
\hline Simon Stevin & 2015-07-31 & 2015-07-31 & North Atlantic & 401 & 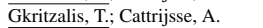 & \\
\hline Simon Stevin & 2015-08-03 & 2015-08-03 & North Atlantic & 394 & 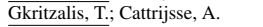 & \\
\hline Simon Stevin & 2015-08-04 & 2015-08-04 & North Atlantic & 412 & $\overline{\text { Gkritzalis, T.; }}$ Cattrijsse, A. & \\
\hline Simon Stevin & 2015-08-07 & 2015-08-07 & North Atlantic & 463 & 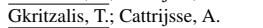 & \\
\hline Simon Stevin & 2015-08-10 & 2015-08-10 & North Atlantic & 479 & Gkritzalis, T; Cattrijsse, A. & \\
\hline Simon Stevin & 2015-08-12 & 2015-08-12 & North Atlantic & 341 & 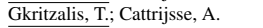 & \\
\hline Simon Stevin & 2015-08-17 & 2015-08-17 & North Atlantic & 439 & 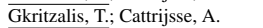 & \\
\hline Simon Stevin & 2015-08-18 & 2015-08-18 & North Atlantic & 414 & Gkritzalis, T; Cattrijsse, A. & \\
\hline Simon Stevin & 2015-08-19 & 2015-08-19 & North Atlantic & 470 & 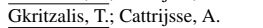 & \\
\hline Simon Stevin & 2015-08-21 & 2015-08-21 & North Atlantic & 401 & 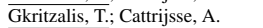 & \\
\hline Simon Stevin & 2015-08-24 & $2015-08-24$ & North Atlantic & 450 & 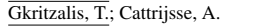 & \\
\hline Simon Stevin & 2015-08-27 & 2015-08-27 & North Atlantic & 373 & 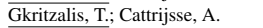 & \\
\hline Simon Stevin & 2015-08-28 & $2015-08-28$ & North Atlantic & 455 & 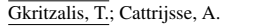 & \\
\hline Simon Stevin & 2015-09-02 & 2015-09-02 & North Atlantic & 961 & 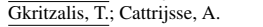 & \\
\hline Simon Stevin & 2015-09-03 & 2015-09-03 & North Atlantic & 450 & 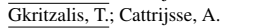 & \\
\hline Simon Stevin & 2015-09-04 & 2015-09-04 & North Atlantic & 307 & Gkritzalis, T.; Cattrijsse, A. & \\
\hline Simon Stevin & 2015-09-08 & 2015-09-08 & North Atlantic & 464 & $\overline{\text { Gkritzalis, T.; }}$ Cattrijsse, A. & \\
\hline
\end{tabular}


Table A1. Continued.

\begin{tabular}{|c|c|c|c|c|c|c|}
\hline Vessel & Start date yyyy-mm-dd & End date yyyy-mm-dd & Regions & No. of samples & Principal investigators & DOI (if available)/comment \\
\hline Simon Stevin & 2015-09-09 & 2015-09-09 & North Atlantic & 436 & Gkritzalis, T.; Cattrijsse, A. & \\
\hline Simon Stevin & 2015-09-10 & 2015-09-10 & North Atlantic & 469 & $\overline{\text { Gkritzalis, T.; }}$ Cattrijsse, A. & \\
\hline Simon Stevin & 2015-09-11 & 2015-09-11 & North Atlantic & 443 & $\overline{\text { Gkritzalis, T.; }}$ Cattrijsse, A. & \\
\hline Simon Stevin & 2015-09-15 & 2015-09-15 & North Atlantic & 729 & 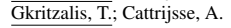 & \\
\hline Simon Stevin & 2015-09-16 & 2015-09-16 & North Atlantic & 1081 & $\overline{\text { Gkritzalis, T.; }}$ Cattrijsse, A. & \\
\hline Simon Stevin & 2015-09-21 & 2015-09-21 & North Atlantic & 366 & $\overline{\text { Gkritzalis, T.; }}$ Cattrijsse, A. & \\
\hline Simon Stevin & 2015-09-25 & 2015-09-25 & North Atlantic & 454 & 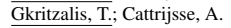 & \\
\hline Simon Stevin & 2015-09-28 & 2015-09-28 & North Atlantic & 440 & 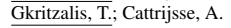 & \\
\hline Simon Stevin & 2015-09-29 & 2015-09-29 & North Atlantic & 701 & $\overline{\text { Gkritzalis, T.; }}$ Cattrijsse, A. & \\
\hline Simon Stevin & 2015-09-30 & 2015-09-30 & North Atlantic & 850 & 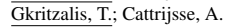 & \\
\hline Simon Stevin & 2015-10-05 & 2015-10-05 & North Atlantic & 453 & $\overline{\text { Gkritzalis, T.; }}$ Cattrijsse, A. & \\
\hline Simon Stevin & 2015-10-06 & 2015-10-06 & North Atlantic & 491 & $\overline{\text { Gkritzalis, T.; }}$ Cattrijsse, A. & \\
\hline Simon Stevin & 2015-10-07 & 2015-10-07 & North Atlantic & 423 & 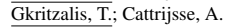 & \\
\hline Simon Stevin & 2015-10-08 & 2015-10-08 & North Atlantic & 437 & $\overline{\text { Gkritzalis, T.; }}$ Cattrijsse, A. & \\
\hline Simon Stevin & 2015-10-10 & 2015-10-10 & North Atlantic & 488 & $\overline{\text { Gkritzalis, T.; }}$ Cattrijsse, A. & \\
\hline Simon Stevin & 2015-10-11 & 2015-10-11 & North Atlantic & 448 & $\overline{\text { Gkritzalis, T.; }}$ Cattrijsse, A. & \\
\hline Simon Stevin & 2015-10-20 & 2015-10-20 & North Atlantic & 435 & $\overline{\text { Gkritzalis, T.; }}$ Cattrijsse, A. & \\
\hline Simon Stevin & 2015-10-21 & 2015-10-21 & North Atlantic & 319 & $\overline{\text { Gkritzalis, T.; }}$ Cattrijsse, A. & \\
\hline Simon Stevin & 2015-11-01 & 2015-11-01 & North Atlantic & 387 & 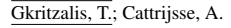 & \\
\hline Simon Stevin & 2015-11-04 & 2015-11-04 & North Atlantic & 272 & 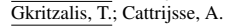 & \\
\hline Simon Stevin & 2015-11-05 & 2015-11-05 & North Atlantic & 415 & $\overline{\text { Gkritzalis, T.; }}$ Cattrijsse, A. & \\
\hline Simon Stevin & 2015-11-06 & 2015-11-06 & North Atlantic & 114 & $\overline{\text { Gkritzalis, T.; }}$ Cattrijsse, A. & \\
\hline Simon Stevin & 2015-11-12 & 2015-11-12 & North Atlantic & 202 & 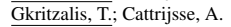 & \\
\hline Simon Stevin & 2015-12-07 & 2015-12-07 & North Atlantic & 217 & 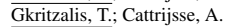 & \\
\hline Simon Stevin & 2015-12-08 & 2015-12-08 & North Atlantic & 336 & Gkritzalis, T.; Cattrijsse, A. & \\
\hline Simon Stevin & 2015-12-09 & 2015-12-09 & North Atlantic & 156 & 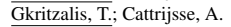 & \\
\hline Soyo Maru & 2015-05-08 & 2015-05-11 & $\begin{array}{l}\text { North Pacific, Tropi- } \\
\text { cal Pacific }\end{array}$ & 3972 & $\overline{\text { Ono, T. }}$ & \\
\hline Soyo Maru & 2015-08-01 & 2015-08-07 & North Pacific & 8354 & Ono, $\mathrm{T}$. & \\
\hline Soyo Maru & 2015-10-26 & 2015-11-03 & North Pacific & 10759 & $\overline{\text { Ono, } \mathrm{T}}$. & \\
\hline Tangaroa & 2015-01-28 & 2015-03-10 & Southern Ocean & 34868 & $\overline{\text { Currie, } \mathrm{K}}$. & doi:10.3334/CDIAC/OTG.VOS_Tangaroa_2015 \\
\hline Tangaroa & 2015-03-27 & 2015-04-14 & Southern Ocean & 15297 & $\overline{\text { Currie, } \mathrm{K}}$. & doi:10.3334/CDIAC/OTG.VOS_Tangaroa_2015 \\
\hline Tangaroa & 2015-04-17 & 2015-04-22 & Southern Ocean & 4797 & $\overline{\text { Currie, } \mathrm{K}}$. & doi:10.3334/CDIAC/OTG.VOS_Tangaroa_2015 \\
\hline Tangaroa & 2015-04-23 & 2015-04-30 & Southern Ocean & 5791 & $\overline{\text { Currie, } \mathrm{K}}$. & doi:10.3334/CDIAC/OTG.VOS_Tangaroa_2015 \\
\hline Tangaroa & 2015-05-04 & 2015-05-21 & Southern Ocean & 12051 & $\overline{\text { Currie, } \mathrm{K}}$. & doi:10.3334/CDIAC/OTG.VOS_Tangaroa_2015 \\
\hline Tangaroa & 2015-05-23 & 2015-06-01 & Southern Ocean & 7985 & $\overline{\text { Currie, } \mathrm{K} \text {. }}$ & doi:10.3334/CDIAC/OTG.VOS_Tangaroa_2015 \\
\hline Tangaroa & 2015-07-04 & 2015-08-02 & Southern Ocean & 26898 & $\overline{\text { Currie, } \mathrm{K}}$. & doi:10.3334/CDIAC/OTG.VOS_Tangaroa_2015 \\
\hline Tangaroa & 2015-08-04 & 2015-08-26 & Southern Ocean & 18553 & $\overline{\text { Currie, } \mathrm{K} \text {. }}$ & doi:10.3334/CDIAC/OTG.VOS_Tangaroa_2015 \\
\hline Tangaroa & 2015-09-05 & 2015-09-24 & Southern Ocean & 12776 & $\overline{\text { Currie, } \mathrm{K} \text {. }}$ & doi:10.3334/CDIAC/OTG.VOS_Tangaroa_2015 \\
\hline Tangaroa & 2015-09-26 & 2015-10-04 & Tropical Pacific & 7207 & $\overline{\text { Currie, K. }}$ & doi:10.3334/CDIAC/OTG.VOS_Tangaroa_2014 \\
\hline Tangaroa & $2015-10-13$ & $2015-10-25$ & Southern Ocean & 10658 & $\overline{\text { Currie, } \mathrm{K}}$. & doi:10.3334/CDIAC/OTG.VOS_Tangaroa_2015 \\
\hline Trans Future 5 & 2015-01-10 & 2015-01-24 & $\begin{array}{l}\text { North Pacific, South- } \\
\text { ern Ocean, } \\
\text { Tropical Pacific }\end{array}$ & 1507 & $\overline{\text { Nojiri, Y. }}$ & doi:10.3334/CDIAC/OTG.VOS_TF5_2015 \\
\hline Trans Future 5 & 2015-01-31 & 2015-02-10 & $\begin{array}{l}\text { North Pacific, Tropi- } \\
\text { cal Pacific }\end{array}$ & 1179 & Nojiri, Y. & doi:10.3334/CDIAC/OTG.VOS_TF5_2015 \\
\hline Trans Future 5 & $2015-02-11$ & $2015-02-24$ & $\begin{array}{l}\text { Southern Ocean, } \\
\text { Tropical Pacific }\end{array}$ & 922 & Nojiri, Y. & doi:10.3334/CDIAC/OTG.VOS_TF5_2015 \\
\hline Trans Future 5 & 2015-02-25 & 2015-03-08 & $\begin{array}{l}\text { North Pacific, South- } \\
\text { ern Ocean, Tropical } \\
\text { Pacific }\end{array}$ & 1379 & Nojiri, Y. & doi:10.3334/CDIAC/OTG.VOS_TF5_2015 \\
\hline Trans Future 5 & 2015-03-14 & 2015-03-24 & $\begin{array}{l}\text { North Pacific, Tropi- } \\
\text { cal Pacific }\end{array}$ & 1083 & Nojiri, Y. & doi:10.3334/CDIAC/OTG.VOS_TF5_2015 \\
\hline Trans Future 5 & 2015-04-25 & 2015-05-05 & $\begin{array}{l}\text { North Pacific, Tropi- } \\
\text { cal Pacific }\end{array}$ & 1090 & Nakaoka, S. & doi:10.3334/CDIAC/OTG.VOS_TF5_2015 \\
\hline Trans Future 5 & 2015-05-06 & $2015-05-20$ & $\begin{array}{l}\text { Southern Ocean, } \\
\text { Tropical Pacific }\end{array}$ & 913 & $\underline{\text { Nakaoka, S. }}$ & doi:10.3334/CDIAC/OTG.VOS_TF5_2015 \\
\hline Trans Future 5 & $2015-05-21$ & 2015-06-01 & $\begin{array}{l}\text { North Pacific, South- } \\
\text { ern Ocean, Tropical } \\
\text { Pacific }\end{array}$ & 1381 & Nakaoka, S. & doi:10.3334/CDIAC/OTG.VOS_TF5_2015 \\
\hline Trans Future 5 & 2015-06-06 & 2015-06-15 & $\begin{array}{l}\text { North Pacific, Tropi- } \\
\text { cal Pacific }\end{array}$ & 1138 & Nakaoka, S. & doi:10.3334/CDIAC/OTG.VOS_TF5_2015 \\
\hline Trans Future 5 & 2015-06-16 & 2015-06-28 & $\begin{array}{l}\text { Southern Ocean, } \\
\text { Tropical Pacific }\end{array}$ & 911 & Nakaoka, S. & doi:10.3334/CDIAC/OTG.VOS_TF5_2015 \\
\hline Trans Future 5 & 2015-06-29 & 2015-07-12 & $\begin{array}{l}\text { North Pacific, South- } \\
\text { ern Ocean, Tropical } \\
\text { Pacific }\end{array}$ & 1431 & Nakaoka, S. & doi:10.3334/CDIAC/OTG.VOS_TF5_2015 \\
\hline Trans Future 5 & 2015-07-18 & 2015-07-30 & $\begin{array}{l}\text { North Pacific, Tropi- } \\
\text { cal Pacific }\end{array}$ & 1112 & Nakaoka, S. & doi:10.3334/CDIAC/OTG.VOS_TF5_2015 \\
\hline Trans Future 5 & 2015-07-30 & $2015-08-11$ & $\begin{array}{l}\text { Southern Ocean, } \\
\text { Tropical Pacific }\end{array}$ & 884 & Nakaoka, S. & doi:10.3334/CDIAC/OTG.VOS_TF5_2015 \\
\hline Trans Future 5 & 2015-08-12 & 2015-08-24 & $\begin{array}{l}\text { North Pacific, South- } \\
\text { ern Ocean, Tropical } \\
\text { Pacific }\end{array}$ & 1400 & Nakaoka, S. & doi:10.3334/CDIAC/OTG.VOS_TF5_2015 \\
\hline Trans Future 5 & 2015-09-26 & 2015-10-07 & $\begin{array}{l}\text { North Pacific, Tropi- } \\
\text { cal Pacific }\end{array}$ & 811 & $\underline{\text { Nakaoka, S. }}$ & doi:10.3334/CDIAC/OTG.VOS_TF5_2015 \\
\hline Trans Future 5 & $2015-10-07$ & 2015-10-19 & $\begin{array}{l}\text { Southern Ocean, } \\
\text { Tropical Pacific }\end{array}$ & 889 & $\underline{\text { Nakaoka, S. }}$ & doi:10.3334/CDIAC/OTG.VOS_TF5_2015 \\
\hline Trans Future 5 & $2015-10-21$ & 2015-11-01 & $\begin{array}{l}\text { North Pacific, South- } \\
\text { ern Ocean, Tropical } \\
\text { Pacific }\end{array}$ & 1427 & Nakaoka, S. & doi:10.3334/CDIAC/OTG.VOS_TF5_2015 \\
\hline Wakataka Maru & $2015-06-30$ & 2015-07-04 & North Pacific & 6356 & $\begin{array}{l}\text { Kuwata, A.; Tadokoro, } \\
\text { Ono, T. }\end{array}$ & \\
\hline Wakataka Maru & 2015-07-11 & 2015-07-21 & North Pacific & 14479 & $\begin{array}{l}\text { Kuwata, A.; } \\
\text { Ono, T. }\end{array}$ & K., \\
\hline Wakataka Maru & 2015-07-29 & 2015-08-05 & North Pacific & 9773 & $\begin{array}{l}\overline{\text { Kuwata, }} \text { A.; } \quad \text { Tadokoro, } \\
\text { Ono, T. }\end{array}$ & K., \\
\hline Wakataka Maru & 2015-09-30 & $2015-10-15$ & North Pacific & 15111 & $\begin{array}{l}\text { Kuwata, A.; } \quad \text { Tadokoro, } \\
\text { Ono, T. }\end{array}$ & \\
\hline
\end{tabular}




\section{Appendix B}

Table B1. Funding supporting the production of the various components of the global carbon budget (see also acknowledgements).

\begin{tabular}{|c|c|}
\hline Funder and grant number (where relevant) & Author initials \\
\hline Australia, Integrated Marine Observing System and Antarctic Climate and Ecosystems CRC & BT \\
\hline $\begin{array}{l}\text { European Commission (EC) Copernicus Atmosphere Monitoring Service, European Centre for } \\
\text { Medium-Range Weather Forecasts (ECMWF) }\end{array}$ & FC \\
\hline EC H2020 (AtlantOS; grant no. 633211) & $\mathrm{NL}, \mathrm{AO}$ \\
\hline EC H2020 (CRESCENDO; grant no. 641816) & $\mathrm{CD}, \mathrm{RS}, \mathrm{OA}, \mathrm{PF}$ \\
\hline EC H2020 European Research Council (ERC) (QUINCY; grant no. 647204). & SZ \\
\hline EC H2020 ERC Synergy grant (IMBALANCE-P; grant no. ERC-2013-SyG-610028) & $\mathrm{PC}$ \\
\hline France, BNP Paribas Foundation grant to support the Global Carbon Atlas & $\mathrm{PC}$ \\
\hline $\begin{array}{l}\text { French Institut National des Sciences de l'Univers (INSU) and Institut Paul Emile Victor (IPEV) for } \\
\text { OISO cruises }\end{array}$ & NM \\
\hline French Institut de recherche pour le développement (IRD) & $\mathrm{NL}$ \\
\hline German Federal Ministry of Education and Research (grant no. 01LK1224I ICOS-D) & MH \\
\hline German Research Foundation's Emmy Noether Programme (grant no. PO1751/1-1) & $\mathrm{JN}$ \\
\hline German Max Planck Society & $\mathrm{CR}, \mathrm{SZ}$ \\
\hline Germany, Federal Ministry of Education and Research (BMBF) & AK \\
\hline $\begin{array}{l}\text { Germany, Helmholtz Postdoc Programme (Initiative and Networking Fund of the Helmholtz Associa- } \\
\text { tion) }\end{array}$ & $\mathrm{JH}$ \\
\hline Japan Ministry of Agriculture, Forestry and Fisheries (MAFF) & OT \\
\hline Japan Ministry of Environment & $\mathrm{SN}$ \\
\hline Japan Ministry of Environment (grant no. ERTDF S-10) & EK \\
\hline NASA LCLUC programme (grant no. NASA NNX14AD94G) & AJ \\
\hline New Zealand National Institute of Water and Atmospheric Research (NIWA) Core Funding & $\mathrm{KC}$ \\
\hline Norway Research Council (grant no. 229752) & AMO \\
\hline Norway Research Council (grant no. 569980) & GPP, RMA, JIK \\
\hline Norway Research Council (project EVA; grant no. 229771) & JS \\
\hline Norwegian Environment Agency (grant no. 16078007) & IS \\
\hline Research Fund - Flanders (FWO; formerly Hercules Foundation) & TG \\
\hline South Africa Council for Scientific and Industrial Research (CSIR) & PMSM \\
\hline UK Natural Environment Research Council (RAGANRAoCC; grant no. NE/K002473/1) & US \\
\hline UK Newton Fund through the Met Office Climate Science for Service Partnership Brazil (CSSP Brazil) & AJW \\
\hline $\begin{array}{l}\text { US Department of Agriculture, National Institute of Food and Agriculture (grant no. 2015-67003- } \\
\text { 23485) }\end{array}$ & DL \\
\hline US Department of Energy (grant no. DE-FC03-97ER62402/A010) & DL \\
\hline $\begin{array}{l}\text { US Department of Energy, Biological and Environmental Research Program, Office of Science (grant } \\
\text { no. DE-AC05-00OR22725) }\end{array}$ & APW \\
\hline US Department of Commerce, NOAA's Climate Observation Division of the Climate Program Office & SRA, AJS \\
\hline US Department of Energy, Office of Science and BER programme (grant no. DOE DE-SC0016323) & AJ \\
\hline US National Science Foundation (grant no. AGS-1048827) & SD \\
\hline US National Science Foundation (grant no. AOAS-1543457) & DRM \\
\hline US National Science Foundation (grant no. AOAS-1341647) & DRM \\
\hline $\begin{array}{l}\text { US NOAA's Climate Observation Division of the Climate Program Office (grant no. N8R1SE3P00); } \\
\text { US NOAA's Ocean Acidification Program (grant no. N8R3CEAP00) }\end{array}$ & DP, LB \\
\hline US National Science Foundation (grant no. NSF AGS 12-43071) & AJ \\
\hline \multicolumn{2}{|l|}{ Computing resources } \\
\hline GENCI (Grand Équipement National de Calcul Intensif; allocation t2016012201), France & FC \\
\hline Météo-France/DSI supercomputing centre & RS \\
\hline Netherlands Organisation for Scientific Research (NWO) (SH-312-14) & IvdL-L \\
\hline $\begin{array}{l}\text { Norwegian Metacenter for Computational Science (NOTUR, project nn2980k) and the Norwegian Stor- } \\
\text { age Infrastructure (NorStore, project ns2980k) }\end{array}$ & JS \\
\hline UEA High Performance Computing Cluster, UK & OA, CLQ \\
\hline
\end{tabular}


Acknowledgements. We thank all people and institutions who provided the data used in this carbon budget; C. Enright, W. Peters, and S. Shu for their involvement in the development, use, and analysis of the models and data products used here; F. Joos and S. Khatiwala for providing historical data; and P. Regnier for assistance in describing LOAC fluxes. We thank E. Dlugokencky, who provided the atmospheric $\mathrm{CO}_{2}$ measurements used here; B. Pfeil, C. Landa, and S. Jones of the Bjerknes Climate Data Centre and the ICOS Ocean Thematic Centre data management at the University of Bergen, who helped with gathering information from the SOCAT community; D. Bakker for support with the SOCAT coordination; and all those involved in collecting and providing oceanographic $\mathrm{CO}_{2}$ measurements used here, in particular for the new ocean data for years 2015: A. Andersson, N. Bates, R. Bott, A. Cattrijsse, E. De Carlo, C. Dietrich, L. Gregor, C. Hunt, T. Johannessen, W. R. Joubert, A. Kuwata, S. K. Lauvset, C. Lo Monaco, S. Maenner, D. Manzello, N. Monacci, S. Musielewicz, T. Newberger, A. Olsen, J. Osborne, C. Sabine, S. C. Sutherland, C. Sweeney, K. Tadokoro, S. van Heuven, D. Vandemark, and R. Wanninkhof. We thank the institutions and funding agencies responsible for the collection and quality control of the data included in SOCAT, and the support of the International Ocean Carbon Coordination Project (IOCCP), the Surface Ocean Lower Atmosphere Study (SOLAS), and the Integrated Marine Biogeochemistry, Ecosystem Research (IMBER) programme. We thank data providers to ObsPack GLOBALVIEWplus v1.0 and NRT v3.0 for atmospheric $\mathrm{CO}_{2}$ observations used in CTE2016-FT. This is NOAA-PMEL contribution number 4576.

Finally, we thank all funders who have supported the individual and joint contributions to this work (see Appendix B), as well as M. Heimann, H. Dolman, and one anonymous reviewer for their comments on our manuscript.

Edited by: D. Carlson

Reviewed by: A. J. Dolman, M. Heimann, and one anonymous referee

\section{References}

Achard, F., Beuchle, R., Mayaux, P., Stibig, H. J., Bodart, C., Brink, A., Carboni, S., Desclée, B., Donnay, F., and Eva, H.: Determination of tropical deforestation rates and related carbon losses from 1990 to 2010, Glob. Change Biol., 20, 2540-2554, 2014.

Andres, R., Boden, T., and Higdon, D.: A new evaluation of the uncertainty associated with CDIAC estimates of fossil fuel carbon dioxide emission, Tellus B, 66, 23616, doi:10.3402/tellusb.v66.23616, 2014.

Andres, R. J., Fielding, D. J., Marland, G., Boden, T. A., Kumar, N., and Kearney, A. T.: Carbon dioxide emissions from fossil fuel use, 1751-1950, Tellus, 51, 759-765, 1999.

Andres, R. J., Boden, T. A., Bréon, F.-M., Ciais, P., Davis, S., Erickson, D., Gregg, J. S., Jacobson, A., Marland, G., Miller, J., Oda, T., Olivier, J. G. J., Raupach, M. R., Rayner, P., and Treanton, K.: A synthesis of carbon dioxide emissions from fossil-fuel combustion, Biogeosciences, 9, 1845-1871, doi:10.5194/bg-9-18452012, 2012.

Andrew, R. M. and Peters, G. P.: A multi-region input-output table based on the Global Trade Analysis Project Database (GTAPMRIO), Economic Systems Research, 25, 99-121, 2013.
Andrew, R. M., Davis, S. J., and Peters, G. P.: Climate policy and dependence on traded carbon, Environ. Res. Lett., 8, 34011, doi:10.1088/1748-9326/8/3/034011, 2013.

Archer, D., Eby, M., Brovkin, V., Ridgwell, A., Cao, L., Mikolajewicz, U., Caldeira, K. M., K., Munhoven, G., Montenegro, A., and Tokos, K.: Atmospheric Lifetime of Fossil Fuel Carbon Dioxide, Annu. Rev. Earth Planet. Sc., 37, 117-134, 2009.

Atlas, R., Hoffman, R. N., Ardizzone, J., Leidner, S. M., Jusem, J. C., Smith, D. K., and Gombos, D.: A cross-calibrated, multiplatform ocean surface wind velocity product for meteorological and oceanographic applications, B. Am. Meteorol. Soc., 92, 157174, 2011.

Aumont, O. and Bopp, L.: Globalizing results from ocean in situ iron fertilization studies, Global Biogeochem. Cyc., 20, GB2017, doi:10.1029/2005GB002591, 2006.

Baccini, A., Goetz, S. J., Walker, W. S., Laporte, N. T., Sun, M., Sulla-Menashe, D., Hackler, J., Beck, P. S. A., Dubayah, R., Friedl, M. A., Samanta, S., and Houghton, R. A.: Estimated carbon dioxide emissions from tropical deforestation improved by carbon-density maps, Nature Climate Change, 2, 182-186, 2012.

Bakker, D. C. E., Pfeil, B., Landa, C. S., Metzl, N., O’Brien, K. M., Olsen, A., Smith, K., Cosca, C., Harasawa, S., Jones, S. D., Nakaoka, S.-I., Nojiri, Y., Schuster, U., Steinhoff, T., Sweeney, C., Takahashi, T., Tilbrook, B., Wada, C., Wanninkhof, R., Alin, S. R., Balestrini, C. F., Barbero, L., Bates, N. R., Bianchi, A. A., Bonou, F., Boutin, J., Bozec, Y., Burger, E. F., Cai, W.-J., Castle, R. D., Chen, L., Chierici, M., Currie, K., Evans, W., Featherstone, C., Feely, R. A., Fransson, A., Goyet, C., Greenwood, N., Gregor, L., Hankin, S., Hardman-Mountford, N. J., Harlay, J., Hauck, J., Hoppema, M., Humphreys, M. P., Hunt, C. W., Huss, B., Ibánhez, J. S. P., Johannessen, T., Keeling, R., Kitidis, V., Körtzinger, A., Kozyr, A., Krasakopoulou, E., Kuwata, A., Landschützer, P., Lauvset, S. K., Lefèvre, N., Lo Monaco, C., Manke, A., Mathis, J. T., Merlivat, L., Millero, F. J., Monteiro, P. M. S., Munro, D. R., Murata, A., Newberger, T., Omar, A. M., Ono, T., Paterson, K., Pearce, D., Pierrot, D., Robbins, L. L., Saito, S., Salisbury, J., Schlitzer, R., Schneider, B., Schweitzer, R., Sieger, R., Skjelvan, I., Sullivan, K. F., Sutherland, S. C., Sutton, A. J., Tadokoro, K., Telszewski, M., Tuma, M., van Heuven, S. M. A. C., Vandemark, D., Ward, B., Watson, A. J., and Xu, S.: A multidecade record of high-quality $f \mathrm{CO}_{2}$ data in version 3 of the Surface Ocean $\mathrm{CO}_{2}$ Atlas (SOCAT), Earth Syst. Sci. Data, 8, 383413, doi:10.5194/essd-8-383-2016, 2016.

Ballantyne, A. P., Alden, C. B., Miller, J. B., Tans, P. P., and White, J. W. C.: Increase in observed net carbon dioxide uptake by land and oceans during the last 50 years, Nature, 488, 70-72, 2012.

Ballantyne, A. P., Andres, R., Houghton, R., Stocker, B. D., Wanninkhof, R., Anderegg, W., Cooper, L. A., DeGrandpre, M., Tans, P. P., Miller, J. B., Alden, C., and White, J. W. C.: Audit of the global carbon budget: estimate errors and their impact on uptake uncertainty, Biogeosciences, 12, 2565-2584, doi:10.5194/bg-122565-2015, 2015.

Bauer, J. E., Cai, W.-J., Raymond, P. A., Bianchi, T. S., Hopkinson, C. S., and Regnier, P. A. G.: The changing carbon cycle of the coastal ocean, Nature, 504, 61-70, 2013.

Best, M. J., Pryor, M., Clark, D. B., Rooney, G. G., Essery, R. L. H., Ménard, C. B., Edwards, J. M., Hendry, M. A., Porson, A., Gedney, N., Mercado, L. M., Sitch, S., Blyth, E., Boucher, O., Cox, P. M., Grimmond, C. S. B., and Harding, R. J.: The Joint 
UK Land Environment Simulator (JULES), model description Part 1: Energy and water fluxes, Geosci. Model Dev., 4, 677-699, doi:10.5194/gmd-4-677-2011, 2011.

Betts, R. A., Jones, C. D., Knight, J. R., Keeling, R. F., and Kennedy, J. J.: El Nino and a record $\mathrm{CO}_{2}$ rise, Nature Climate Change, 6 , 806-810, 2016.

Boden, T. A. and Andres, R. J.: Global, Regional, and National Fossil-Fuel $\mathrm{CO}_{2}$ Emissions, available at: http://cdiac.ornl.gov/ trends/emis/overview_2013.html (last access: April 2016), Oak Ridge National Laboratory, US Department of Energy, Oak Ridge, Tenn., USA, 2016.

BP: Change in methodology for calculating $\mathrm{CO}_{2}$ emissions from energy use, available at: http://www.bp.com/content/dam/bp/pdf/energy-economics/ statistical-review-2016/bp-statistical-review-of-world-energy2016-carbon-emissions-methodology.pdf (last access: September 2016), 2016a.

BP: Statistical Review of World Energy 2016, available at: https://www.bp.com/content/dam/bp/pdf/ energyeconomics/statistical-review-2016/bp-statistical-review-ofworld-energy-2016-full-report.pdf (last access: June 2016), 2016b.

Bruno, M. and Joos, F.: Terrestrial carbon storage during the past 200 years: A monte carlo analysis of $\mathrm{CO}_{2}$ data from ice core and atmospheric measurements, Global Biogeochem. Cy., 11, 111124, 1997.

Buitenhuis, E. T., Rivkin, R. B., Sailley, S., and Le Quéré, C.: Biogeochemical fluxes through microzooplankton, Global Biogeochem. Cy., 24, GB4015, doi:10.1029/2009gb003601, 2010.

Canadell, J., Ciais, P., Sabine, C., and Joos, F. (Eds.): REgional Carbon Cycle Assessment and Processes (RECCAP), Biogeosciences, http://www.biogeosciences.net/special_issue107.html, 2012.

Canadell, J. G., Le Quéré, C., Raupach, M. R., Field, C. B., Buitenhuis, E. T., Ciais, P., Conway, T. J., Gillett, N. P., Houghton, R. A., and Marland, G.: Contributions to accelerating atmospheric $\mathrm{CO}_{2}$ growth from economic activity, carbon intensity, and efficiency of natural sinks, P. Natl. Acad. Sci. USA, 104, 1886618870, 2007.

CCIA: China Coal Industry Association, 2016 First Three Quarters of Economic Operation of Coal, available at: http://www. coalchina.org.cn/detail/16/10/25/00000007/content.html, last access: 29 October 2016 (in Chinese).

Chevallier, F.: On the statistical optimality of $\mathrm{CO}_{2}$ atmospheric inversions assimilating $\mathrm{CO}_{2}$ column retrievals, Atmos. Chem. Phys., 15, 11133-11145, doi:10.5194/acp-15-11133-2015, 2015.

Chevallier, F., Fisher, M., Peylin, P., Serrar, S., Bousquet, P., Bréon, F.-M., Chédin, A., and Ciais, P.: Inferring $\mathrm{CO}_{2}$ sources and sinks from satellite observations: Method and application to TOVS data, J. Geophys. Res., 110, D24309, doi:10.1029/2005JD006390, 2005.

Ciais, P., Sabine, C., Govindasamy, B., Bopp, L., Brovkin, V., Canadell, J., Chhabra, A., DeFries, R., Galloway, J., Heimann, M., Jones, C., Le Quéré, C., Myneni, R., Piao, S., and Thornton, P.: Chapter 6: Carbon and Other Biogeochemical Cycles, in: Climate Change 2013 The Physical Science Basis, edited by: Stocker, T., Qin, D., and Platner, G.-K., Cambridge University Press, Cambridge, 2013.
Clark, D. B., Mercado, L. M., Sitch, S., Jones, C. D., Gedney, N., Best, M. J., Pryor, M., Rooney, G. G., Essery, R. L. H., Blyth, E., Boucher, O., Harding, R. J., Huntingford, C., and Cox, P. M.: The Joint UK Land Environment Simulator (JULES), model description - Part 2: Carbon fluxes and vegetation dynamics, Geosci. Model Dev., 4, 701-722, doi:10.5194/gmd-4-701-2011, 2011.

Davis, S. J. and Caldeira, K.: Consumption-based accounting of $\mathrm{CO}_{2}$ emissions, P. Natl. Acad. Sci. USA, 107, 5687-5692, 2010.

Denman, K. L., Brasseur, G., Chidthaisong, A., Ciais, P., Cox, P. M., Dickinson, R. E., Hauglustaine, D., Heinze, C., Holland, E., Jacob, D., Lohmann, U., Ramachandran, S., da Silva Dias, P. L., Wofsy, S. C., and Zhang, X.: Couplings Between Changes in the Climate System and Biogeochemistry, in: Climate Change 2007: The Physical Science Basis. Contribution of Working Group I to the Fourth Assessment Report of the Intergovernmental Panel on Climate Change, edited by: Solomon, S., Qin, D., Manning, M., Chen, Z., Marquis, M., Averyt, K. B., Tignor, M., and Miller, H. L., Cambridge University Press, Cambridge, UK and New York, USA, 2007.

Dietzenbacher, E., Pei, J. S., and Yang, C. H.: Trade, production fragmentation, and China's carbon dioxide emissions, J. Environ. Econ. Manag., 64, 88-101, 2012.

Dlugokencky, E. and Tans, P.: Trends in atmospheric carbon dioxide, National Oceanic \& Atmospheric Administration, Earth System Research Laboratory (NOAA/ESRL), available at: http:// www.esrl.noaa.gov/gmd/ccgg/trends/global.html, last access: 28 October 2016.

Doney, S. C., Lima, I., Feely, R. A., Glover, D. M., Lindsay, K., Mahowald, N., Moore, J. K., and Wanninkhof, R.: Mechanisms governing interannual variability in upper-ocean inorganic carbon system and air-sea $\mathrm{CO}_{2}$ fluxes: Physical climate and atmospheric dust, Deep-Sea Res. Pt. II, 56, 640-655, 2009.

Duce, R. A., LaRoche, J., Altieri, K., Arrigo, K. R., Baker, A. R., Capone, D. G., Cornell, S., Dentener, F., Galloway, J., Ganeshram, R. S., Geider, R. J., Jickells, T., Kuypers, M. M., Langlois, R., Liss, P. S., Liu, S. M., Middelburg, J. J., Moore, C. M., Nickovic, S., Oschlies, A., Pedersen, T., Prospero, J., Schlitzer, R., Seitzinger, S., Sorensen, L. L., Uematsu, M., Ulloa, O., Voss, M., Ward, B., and Zamora, L.: Impacts of atmospheric anthropogenic nitrogen on the open ocean, Science, 320, 893-897, 2008.

Durant, A. J., Le Quéré, C., Hope, C., and Friend, A. D.: Economic value of improved quantification in global sources and sinks of carbon dioxide, Philos. T. Roy. Soc. A, 369, 1967-1979, doi:10.1098/rsta.2011.0002, 2011.

Earles, J. M., Yeh, S., and Skog, K. E.: Timing of carbon emissions from global forest clearance, Nature Climate Change, 2, 682685, 2012.

EDGAR: Global Emissions EDGAR v4.2 (November 2011), available at: http://edgar.jrc.ec.europa.eu/overview.php?v=42 (last access: October 2016), 2011.

EIA: US Energy Information Administration, Short-Term Energy and Winter Fuels Outlook, available at: http://www.eia.gov/ forecasts/steo/outlook.cfm, last access: October 2016.

Elliott, J., Müller, C., Deryng, D., Chryssanthacopoulos, J., Boote, K. J., Büchner, M., Foster, I., Glotter, M., Heinke, J., Iizumi, T., Izaurralde, R. C., Mueller, N. D., Ray, D. K., Rosenzweig, C., Ruane, A. C., and Sheffield, J.: The Global Gridded Crop Model Intercomparison: data and modeling protocols for Phase 1 (v1.0), 
Geosci. Model Dev., 8, 261-277, doi:10.5194/gmd-8-261-2015, 2015.

El Masri, B., Shu, S., and Jain, A. K.: Implementation of a dynamic rooting depth and phenology into a land surface model: Evaluation of carbon, water, and energy fluxes in the high latitude ecosystems, Agr. Forest Meteorol., 211-212, 85-99, 2015.

Erb, K.-H., Kastner, T., Luyssaert, S., Houghton, R. A., Kuemmerle, T., Olofsson, P., and Haberl, H.: Bias in the attribution of forest carbon sinks, Nature Climate Change, 3, 854-856, 2013.

Etheridge, D. M., Steele, L. P., Langenfelds, R. L., and Francey, R. J.: Natural and anthropogenic changes in atmospheric $\mathrm{CO}_{2}$ over the last 1000 years from air in Antarctic ice and firn, J. Geophys. Res., 101, 4115-4128, 1996.

FAO: Global Forest Resource Assessment 2010, 378 pp., Food and Agriculture Organization of the United Nations, Rome, Italy 2010.

FAOSTAT: Food and Agriculture Organization Statistics Division, available at: http://faostat.fao.org/ (last access: October 2012), 2010.

Federici, S., Tubiello, F. N., Salvatore, M., Jacobs, H., and Schmidhuber, J.: New estimates of $\mathrm{CO}_{2}$ forest emissions and removals: 1990-2015, Forest Ecol. Manage., 352, 89-98, 2015.

Feely, R. A., Wanninkhof, R., Takahashi, T., and Tans, P.: Influence of El Nino on the equatorial Pacific contribution to atmospheric $\mathrm{CO}_{2}$ accumulation, Nature, 398, 597-601, 1999.

Francey, R. J., Trudinger, C. M., van der Schoot, M., Law, R. M., Krummel, P. B., Langenfelds, R. L., Steele, L. P., Allison, C. E., Stavert, A. R., Andres, R. J., and Rodenbeck, C.: Reply to "Anthropogenic $\mathrm{CO}_{2}$ emissions", Nature Climate Change, 3, 604604, 2013.

Friedlingstein, P., Houghton, R. A., Marland, G., Hackler, J., Boden, T. A., Conway, T. J., Canadell, J. G., Raupach, M. R., Ciais, P., and Le Quéré, C.: Update on $\mathrm{CO}_{2}$ emissions, Nat. Geosci., 3, 811-812, 2010.

Friedlingstein, P., Andrew, R. M., Rogelj, J., Peters, G. P., Canadell, J. G., Knutti, R., Luderer, G., Raupach, M. R., Schaeffer, M., van Vuuren, D. P., and Le Quéré, C.: Persistent growth of $\mathrm{CO}_{2}$ emissions and implications for reaching climate targets, Nat. Geosci., 7, 709-715, doi:10.1038/ngeo2248, 2014.

Gasser, T. and Ciais, P.: A theoretical framework for the net landto-atmosphere $\mathrm{CO}_{2}$ flux and its implications in the definition of "emissions from land-use change", Earth Syst. Dynam., 4, 171186, doi:10.5194/esd-4-171-2013, 2013.

GCP: The Global Carbon Budget 2007, available at: http://www. globalcarbonproject.org/carbonbudget/archive.htm (last access: 7 November 2016), 2007.

Giglio, L., Randerson, J., and van der Werf, G.: Analysis of daily, monthly, and annual burned area using the fourth-generation global fire emissions database (GFED4), J. Geophys. Res.Biogeo., 118, 317-328, doi:10.1002/jgrg.20042, 2013.

Gitz, V. and Ciais, P.: Amplifying effects of land-use change on future atmospheric $\mathrm{CO}_{2}$ levels, Global Biogeochem. Cy., 17, 1024, doi:10.1029/2002GB001963, 2003.

Goll, D. S., Brovkin, V., Liski, J., Raddatz, T., Thum, T., and ToddBrown, K. E. O.: Strong dependence of $\mathrm{CO}_{2}$ emissions from anthropogenic land cover change on initial land cover and soil carbon parametrization, Global Biogeochem. Cy., 29, 1511-1523, doi:10.1002/2014gb004988, 2015.
Gonzalez-Gaya, B., Fernandez-Pinos, M. C., Morales, L., Mejanelle, L., Abad, E., Pina, B., Duarte, C. M., Jimenez, B., and Dachs, J.: High atmosphere-ocean exchange of semivolatile aromatic hydrocarbons, Nat. Geosci., 9, 438-442, doi:10.1038/ngeo2714, 2016.

Gregg, J. S., Andres, R. J., and Marland, G.: China: Emissions pattern of the world leader in $\mathrm{CO}_{2}$ emissions from fossil fuel consumption and cement production, Geophys. Res. Lett., 35, L08806, doi:10.1029/2007GL032887, 2008.

Harris, I., Jones, P. D., Osborn, T. J., and Lister, D. H.: Updated high-resolution grids of monthly climatic observations - the CRU TS3.10 Dataset, Int. J. Climatol., 34, 623-642, 2014.

Harris, N., Brown, S., and Hagen, S. C.: Baseline map of carbon emissions from deforestation in tropical regions, Science, 336, 1573-1576, 2012.

Hauck, J., Köhler, P., Wolf-Gladrow, D., and Völker, C.: Iron fertilisation and century-scale effects of open ocean dissolution of olivine in a simulated $\mathrm{CO}_{2}$ removal experiment, Environ. Res. Lett., 11, 024007, doi:10.1088/1748-9326/11/2/024007, 2016.

Hertwich, E. G. and Peters, G. P.: Carbon Footprint of Nations: A Global, Trade-Linked Analysis, Environ. Sci. Tech., 43, 64146420, doi:10.1021/es803496a, 2009.

Houghton, R. A.: Revised estimates of the annual net flux of carbon to the atmosphere from changes in land use and land management 1850-2000, Tellus B, 55, 378-390, 2003.

Houghton, R. A. and Nassikas, A. A.: Global and regional fluxes of carbon from land use and land-cover change 1850-2015, Global Biogeochem. Cy., submitted, 2016.

Houghton, R. A., House, J. I., Pongratz, J., van der Werf, G. R., DeFries, R. S., Hansen, M. C., Le Quéré, C., and Ramankutty, N.: Carbon emissions from land use and land-cover change, Biogeosciences, 9, 5125-5142, doi:10.5194/bg-9-5125-2012, 2012.

Hourdin, F., Musat, I., Bony, S., Braconnot, P., Codron, F., Dufresne, J.-L., Fairhead, L., Filiberti, M.-A., Freidlingstein, P., Grandpeix, J.-Y., Krinner, G., LeVan, P., Li, Z.-X., and Lott, F.: The LMDZ4 general circulation model: climate performance and sensitivity to parametrized physics with emphasis on tropical convection, Clim. Dynam., 27, 787-813, doi:10.1007/s00382006-0158-0, 2006.

Hurtt, G. C., Chini, L. P., Frolking, S., Betts, R. A., Feddema, J., Fischer, G., Fisk, J. P., Hibbard, K., Houghton, R. A., Janetos, A., Jones, C. D., Kindermann, G., Kinoshita, T., Goldewijk, K. K., Riahi, K., Shevliakova, E., Smith, S., Stehfest, E., Thomson, A., Thornton, P., van Vuuren, D. P., and Wang, Y. P.: Harmonization of land-use scenarios for the period 1500-2100: 600 years of global gridded annual land-use transitions, wood harvest, and resulting secondary lands, Climatic Change, 109, 117161, doi:10.1007/s10584-011-0153-2, 2011.

IEA/OECD: $\mathrm{CO}_{2}$ emissions from fuel combustion, International Energy Agency/Organisation for Economic Cooperation and Development, Paris, 152 pp., 2015.

IEW: International Energy Web, available at: http://gas.in-en.com/ html/gas-2517194.shtml, last access: 11 October 2016 (in Chinese).

IMF: World Economic Outlook of the International Monetary Fund, available at: http://www.imf.org/external/ns/cs.aspx?id=29, last access: September 2016. 
Inomata, S. and Owen, A.: COMPARATIVE EVALUATION OF MRIO DATABASES, Economic Systems Research, 26, 239244, 2014.

Ito, A. and Inatomi, M.: Use of a process-based model for assessing the methane budgets of global terrestrial ecosystems and evaluation of uncertainty, Biogeosciences, 9, 759-773, doi:10.5194/bg9-759-2012, 2012.

Jackson, R. B., Canadell, J. G., Le Quéré, C., Andrew, R. M., Korsbakken, J. I., Peters, G. P., and Nakicenovic, N.: Reaching peak emissions, Nature Climate Change, 6, 7-10, doi:10.1038/nclimate2892,, 2016.

Jacobson, A. R., Mikaloff Fletcher, S. E., Gruber, N., Sarmiento, J. L., and Gloor, M.: A joint atmosphere-ocean inversion for surface fluxes of carbon dioxide: 1. Methods and global-scale fluxes, Global Biogeochem. Cy., 21, GB1019, doi:10.1029/2005GB002556, 2007.

Jain, A. K., Meiyappan, P., Song, Y., and House, J. I.: $\mathrm{CO}_{2}$ Emissions from Land-Use Change Affected More by Nitrogen Cycle, than by the Choice of Land Cover Data, Glob. Change Biol., 9, 2893-2906, 2013.

Joos, F. and Spahni, R.: Rates of change in natural and anthropogenic radiative forcing over the past 20,000 years, P. Natl. Acad. Sci. USA, 105, 1425-1430, 2008.

Karstensen, J., Peters, G. P., and Andrew, R. M.: Uncertainty in temperature response of current consumption-based emissions estimates, Earth Syst. Dynam., 6, 287-309, doi:10.5194/esd-6-2872015, 2015.

Kato, E., Kinoshita, T., Ito, A., Kawamiya, M., and Yamagata, Y.: Evaluation of spatially explicit emission scenario of land-use change and biomass burning using a process-based biogeochemical model, Journal of Land Use Science, 8, 104-122, 2013.

Keeling, C. D., Bacastow, R. B., Bainbridge, A. E., Ekdhal, C. A., Guenther, P. R., and Waterman, L. S.: Atmospheric carbon dioxide variations at Mauna Loa Observatory, Hawaii, Tellus, 28, 538-551, 1976.

Keeling, R. F. and Manning, A. C.: 5.15 - Studies of Recent Changes in Atmospheric $\mathrm{O}_{2}$ Content, in: Treatise on Geochemistry (Second Edition), edited by: Holland, H. D. and Turekian, K. K., Elsevier, Oxford, 385-404, doi:10.1016/B9780-08-095975-7.00420-4, 2014.

Khatiwala, S., Primeau, F., and Hall, T.: Reconstruction of the history of anthropogenic $\mathrm{CO}_{2}$ concentrations in the ocean, Nature, 462, 346-350, 2009.

Khatiwala, S., Tanhua, T., Mikaloff Fletcher, S., Gerber, M., Doney, S. C., Graven, H. D., Gruber, N., McKinley, G. A., Murata, A., Ríos, A. F., and Sabine, C. L.: Global ocean storage of anthropogenic carbon, Biogeosciences, 10, 2169-2191, doi:10.5194/bg-10-2169-2013, 2013.

Kirschke, S., Bousquet, P., Ciais, P., Saunois, M., Canadell, J. G., Dlugokencky, E. J., Bergamaschi, P., Bergmann, D., Blake, D. R., Bruhwiler, L., Cameron Smith, P., Castaldi, S., Chevallier, F., Feng, L., Fraser, A., Heimann, M., Hodson, E. L., Houweling, S., Josse, B., Fraser, P. J., Krummel, P. B., Lamarque, J., Langenfelds, R. L., Le Quéré, C., Naik, V., O’Doherty, S., Palmer, P. I., Pison, I., Plummer, D., Poulter, B., Prinn, R. G., Rigby, M., Ringeval, B., Santini, M., Schmidt, M., Shindell, D. T., Simpson, I. J., Spahni, R., Steele, L. P., Strode, S. A., Sudo, K., Szopa, S., van der Werf, G. R., Voulgarakis, A., van Weele, M., Weiss, R. F.,
Williams, J. E., and Zeng, G.: Three decades of global methane sources and sinks, Nat. Geosci., 6, 813-823, 2013.

Klein Goldewijk, K., Beusen, A., van Drecht, G., and de Vos, M.: The HYDE 3.1 spatially explicit database of human-induced global land-use change over the past 12,000 years, Glob. Ecol. Biogeogr., 20, 73-86, 2011.

Korsbakken, J. I., Peters, G. P., and Andrew, R. M.: Uncertainties around reductions in China's coal use and $\mathrm{CO}_{2}$ emissions, Nature Climate Change, 6, 687-690, doi:10.1038/nclimate2963, 2016.

Krinner, G., Viovy, N., de Noblet, N., Ogée, J., Friedlingstein, P., Ciais, P., Sitch, S., Polcher, J., and Prentice, I. C.: A dynamic global vegetation model for studies of the coupled atmospherebiosphere system, Global Biogeochem. Cy., 19, 1-33, 2005.

Landschützer, P., Gruber, N., Bakker, D. C. E., and Schuster, U.: Recent variability of the global ocean carbon sink, Global Biogeochem. Cy., 28, 927-949, doi:10.1002/2014GB004853, 2014.

Landschützer, P., Gruber, N., Haumann, F. A., Rödenbeck, C., Bakker, D. C. E., van Heuven, S., Hoppema, M., Metzl, N., Sweeney, C., Takahashi, T., Tilbrook, B., and Wanninkhof, R.: The reinvigoration of the Southern Ocean carbon sink, Science, 349, 1221-1224, 2015.

Landschützer, P., Gruber, N., and Bakker, D. C. E.: Decadal variations and trends of the global ocean carbon sink, Global Biogeochem. Cy., doi:10.1002/2015GB005359, online first, 2016.

Le Quéré, C.: Closing the global budget for $\mathrm{CO}_{2}$, Global Change, 74, 28-31, 2009.

Le Quéré, C., Raupach, M. R., Canadell, J. G., Marland, G., Bopp, L., Ciais, P., Conway, T. J., Doney, S. C., Feely, R. A., Foster, P., Friedlingstein, P., Gurney, K., Houghton, R. A., House, J. I., Huntingford, C., Levy, P. E., Lomas, M. R., Majkut, J., Metzl, N., Ometto, J. P., Peters, G. P., Prentice, I. C., Randerson, J. T., Running, S. W., Sarmiento, J. L., Schuster, U., Sitch, S., Takahashi, T., Viovy, N., van der Werf, G. R., and Woodward, F. I.: Trends in the sources and sinks of carbon dioxide, Nat. Geosci., 2, 831-836, 2009.

Le Quéré, C., Andres, R. J., Boden, T., Conway, T., Houghton, R. A., House, J. I., Marland, G., Peters, G. P., van der Werf, G. R., Ahlström, A., Andrew, R. M., Bopp, L., Canadell, J. G., Ciais, P., Doney, S. C., Enright, C., Friedlingstein, P., Huntingford, C., Jain, A. K., Jourdain, C., Kato, E., Keeling, R. F., Klein Goldewijk, K., Levis, S., Levy, P., Lomas, M., Poulter, B., Raupach, M. R., Schwinger, J., Sitch, S., Stocker, B. D., Viovy, N., Zaehle, S., and Zeng, N.: The global carbon budget 1959-2011, Earth Syst. Sci. Data, 5, 165-185, doi:10.5194/essd-5-165-2013, 2013 Le Quéré, C., Peters, G. P., Andres, R. J., Andrew, R. M., Boden, T. A., Ciais, P., Friedlingstein, P., Houghton, R. A., Marland, G., Moriarty, R., Sitch, S., Tans, P., Arneth, A., Arvanitis, A., Bakker, D. C. E., Bopp, L., Canadell, J. G., Chini, L. P., Doney, S. C., Harper, A., Harris, I., House, J. I., Jain, A. K., Jones, S. D., Kato, E., Keeling, R. F., Klein Goldewijk, K., Körtzinger, A., Koven, C., Lefèvre, N., Maignan, F., Omar, A., Ono, T., Park, G.-H., Pfeil, B., Poulter, B., Raupach, M. R., Regnier, P., Rödenbeck, C., Saito, S., Schwinger, J., Segschneider, J., Stocker, B D., Takahashi, T., Tilbrook, B., van Heuven, S., Viovy, N., Wanninkhof, R., Wiltshire, A., and Zaehle, S.: Global carbon budget 2013, Earth Syst. Sci. Data, 6, 235-263, doi:10.5194/essd-6-2352014, 2014.

Le Quéré, C., Moriarty, R., Andrew, R. M., Canadell, J. G., Sitch, S., Korsbakken, J. I., Friedlingstein, P., Peters, G. P., Andres, R. J., 
Boden, T. A., Houghton, R. A., House, J. I., Keeling, R. F., Tans, P., Arneth, A., Bakker, D. C. E., Barbero, L., Bopp, L., Chang, J., Chevallier, F., Chini, L. P., Ciais, P., Fader, M., Feely, R. A., Gkritzalis, T., Harris, I., Hauck, J., Ilyina, T., Jain, A. K., Kato, E., Kitidis, V., Klein Goldewijk, K., Koven, C., Landschützer, P., Lauvset, S. K., Lefèvre, N., Lenton, A., Lima, I. D., Metzl, N., Millero, F., Munro, D. R., Murata, A., Nabel, J. E. M. S., Nakaoka, S., Nojiri, Y., O’Brien, K., Olsen, A., Ono, T., Pérez, F. F., Pfeil, B., Pierrot, D., Poulter, B., Rehder, G., Rödenbeck, C., Saito, S., Schuster, U., Schwinger, J., Séférian, R., Steinhoff, T., Stocker, B. D., Sutton, A. J., Takahashi, T., Tilbrook, B., van der Laan-Luijkx, I. T., van der Werf, G. R., van Heuven, S., Vandemark, D., Viovy, N., Wiltshire, A., Zaehle, S., and Zeng, N.: Global Carbon Budget 2015, Earth Syst. Sci. Data, 7, 349-396, doi:10.5194/essd-7-349-2015, 2015a.

Le Quéré, C., Moriarty, R., Andrew, R. M., Peters, G. P., Ciais, P., Friedlingstein, P., Jones, S. D., Sitch, S., Tans, P., Arneth, A., Boden, T. A., Bopp, L., Bozec, Y., Canadell, J. G., Chini, L. P., Chevallier, F., Cosca, C. E., Harris, I., Hoppema, M., Houghton, R. A., House, J. I., Jain, A. K., Johannessen, T., Kato, E., Keeling, R. F., Kitidis, V., Klein Goldewijk, K., Koven, C., Landa, C. S., Landschützer, P., Lenton, A., Lima, I. D., Marland, G., Mathis, J. T., Metzl, N., Nojiri, Y., Olsen, A., Ono, T., Peng, S., Peters, W., Pfeil, B., Poulter, B., Raupach, M. R., Regnier, P., Rödenbeck, C., Saito, S., Salisbury, J. E., Schuster, U., Schwinger, J., Séférian, R., Segschneider, J., Steinhoff, T., Stocker, B. D., Sutton, A. J., Takahashi, T., Tilbrook, B., van der Werf, G. R., Viovy, N., Wang, Y.-P., Wanninkhof, R., Wiltshire, A., and Zeng, N.: Global carbon budget 2014, Earth Syst. Sci. Data, 7, 47-85, doi:10.5194/essd-7-47-2015, 2015b.

Li, W., Ciais, P., Wang, Y., Peng, S., Broquet, G., Ballantyne, A. P., Canadell, J. G., Cooper, L., Friedlingstein, P., Le Quéré, C., Myneni, R., Peters, G. P., Piao, S., and Pongratz, J.: Reducing uncertainties in decadal variability of the global carbon budget with multiple datasets, P. Natl. Acad. Sci. USA, doi:10.1073/pnas.1603956113, in press, 2016.

Liu, Z., Guan, D., Wei, W., Davis, S. J., Ciais, P., Bai, J., Peng, S., Zhang, Q., Hubacek, K., Marland, G., Andres, R. J., CrawfordBrown, D., Lin, J., Zhao, H., Hong, C., Boden, T. A., Feng, K., Peters, G. P., Xi, F., Liu, J., Li, Y., Zhao, Y., Zeng, N., and He, K.: Reduced carbon emission estimates from fossil fuel combustion and cement production in China, Nature, 524, 335-338, doi:10.1038/nature14677, 2015.

Manning, A. C. and Keeling, R. F.: Global oceanic and land biotic carbon sinks from the Scripps atmospheric oxygen flask sampling network, Tellus B, 58, 95-116, doi:10.1111/j.16000889.2006.00175.x, 2006.

Marland, G.: Uncertainties in accounting for $\mathrm{CO}_{2}$ from fossil fuels, J. Ind. Ecol., 12, 136-139, 2008.

Marland, G., Andres, R. J., Blasing, T. J., Boden, T. A., Broniak, C. T., Gregg, J. S., Losey, L. M., and Treanton, K.: Energy, industry and waste management activities: An introduction to $\mathrm{CO}_{2}$ emissions from fossil fuels, A report by the US Climate Change Science Program and the Subcommittee on Global Change Research, in: The First State of the Carbon Cycle Report (SOCCR): The North American Carbon Budget and Implications for the Global Carbon Cycle, edited by: King, A. W., Dilling, L., Zimmerman, G. P., Fairman, D. M., Houghton, R. A., Marland, G.,
Rose, A. Z., and Wilbanks, T. J., National Oceanic and Atmospheric Administration, Asheville, NC, 2007.

Marland, G., Hamal, K., and Jonas, M.: How Uncertain Are Estimates of $\mathrm{CO}_{2}$ Emissions?, J. Ind. Ecol., 13, 4-7, 2009.

Masarie, K. A. and Tans, P. P.: Extension and integratino of atmospheric carbon dioxide data into a globally consistent measurement record, J. Geophys. Res.-Atmos., 100, 11593-11610, 1995.

McNeil, B. I., Matear, R. J., Key, R. M., Bullister, J. L., and Sarmiento, J. L.: Anthropogenic $\mathrm{CO}_{2}$ uptake by the ocean based on the global chlorofluorocarbon data set, Science, 299, 235239, 2003.

Melton, J. R. and Arora, V. K.: Competition between plant functional types in the Canadian Terrestrial Ecosystem Model (CTEM) v. 2.0, Geosci. Model Dev., 9, 323-361, doi:10.5194/gmd-9-323-2016, 2016.

Meyerholt, J., Zaehle, S., and Smith, M. J.: Variability of projected terrestrial biosphere responses to elevated levels of atmospheric $\mathrm{CO}_{2}$ due to uncertainty in biological nitrogen fixation, Biogeosciences, 13, 1491-1518, doi:10.5194/bg-13-1491-2016, 2016.

Mikaloff Fletcher, S. E., Gruber, N., Jacobson, A. R., Doney, S. C., Dutkiewicz, S., Gerber, M., Follows, M., Joos, F., Lindsay, K., Menemenlis, D., Mouchet, A., Müller, S. A., and Sarmiento, J. L.: Inverse estimates of anthropogenic $\mathrm{CO}_{2}$ uptake, transport, and storage by the oceans, Global Biogeochem. Cy., 20, GB2002, doi:10.1029/2005GB002530, 2006.

Moran, D. and Wood, R.: CONVERGENCE BETWEEN THE EORA, WIOD, EXIOBASE, AND OPENEU'S CONSUMPTION-BASED CARBON ACCOUNTS, Economic Systems Research, 26, 245-261, 2014.

Myhre, G., Alterskjær, K., and Lowe, D.: A fast method for updating global fossil fuel carbon dioxide emissions, Environ. Res. Lett., 4, 034012, doi:10.1088/1748-9326/4/3/034012, 2009.

Narayanan, B., Aguiar, A., and McDougall, R.: available at: https: //www.gtap.agecon.purdue.edu/databases/v9/default.asp, last access: September 2015.

NBS: National Bureau of Statistic, Industrial Production Operation in September 2016, available at: http://www.stats.gov.cn/english/ PressRelease/201610/t20161020_1411993.html, last access: October 2016.

NDRC: National Development and Reform Commission, Natural Gas, available at: http://www.sdpc.gov.cn/jjxsfx/201608/ t20160826_816043.html, last access: 26 August 2016a.

NDRC: National Development and Reform Commission, Refined oil, available at: http://www.sdpc.gov.cn/jjxsfx/201608/ t20160826_816042.html (last access: August 2016), 2016b.

NOAA/ESRL: available at: http://www.esrl.noaa.gov/gmd/ccgg/ about/global_means.html, last access: 7 October 2015.

Oke, P. R., Griffin, D. A., Schiller, A., Matear, R. J., Fiedler, R., Mansbridge, J., Lenton, A., Cahill, M., Chamberlain, M. A., and Ridgway, K.: Evaluation of a near-global eddy-resolving ocean model, Geosci. Model Dev., 6, 591-615, doi:10.5194/gmd-6591-2013, 2013.

Oleson, K. W., Lawrence, D. M., Bonan, G. B., Drewniak, B., Huang, M., Koven, C. D., Levis, S., Li, F., Riley, W. J., Subin, Z. M., Swenson, S. C., Thornton, P. E., Bozbiyik, A., Fisher, R., Heald, C. L., Kluzek, E., Lamarque, J., Lawrence, P. J., Leung, L. R., Lipscomb, W., Muszala, S., Ricciuto, D. M., Sacks, W., Tang, J., and Yang, Z.: Technical Description of version 4.5 of the Community Land Model (CLM), 
National Center for Atmospheric Research, Boulder, CO, USA, available at: http://www.cesm.ucar.edu/models/cesm1.2/ clm/CLM45_Tech_Note.pdf (last access: 8 November 2016), 2013.

Olin, S., Lindeskog, M., Pugh, T. A. M., Schurgers, G., Wårlind, D., Mishurov, M., Zaehle, S., Stocker, B. D., Smith, B., and Arneth, A.: Soil carbon management in large-scale Earth system modelling: implications for crop yields and nitrogen leaching, Earth Syst. Dynam., 6, 745-768, doi:10.5194/esd-6-745-2015, 2015.

Peters, G. P. and Hertwich, E. G.: Post-Kyoto Greenhouse Gas Inventories: Production versus Consumption, Climatic Change, 86, 51-66, doi:10.1007/s10584-007-9280-1, 2008.

Peters, G. P., Andrew, R., and Lennos, J.: Constructing a multiregional input-output table using the GTAP database, Economic Systems Research, 23, 131-152, 2011a.

Peters, G. P., Minx, J. C., Weber, C. L., and Edenhofer, O.: Growth in emission transfers via international trade from 1990 to 2008 , P. Natl. Acad. Sci. USA, 108, 8903-8908, 2011 b.

Peters, G. P., Davis, S. J., and Andrew, R.: A synthesis of carbon in international trade, Biogeosciences, 9, 3247-3276, doi:10.5194/bg-9-3247-2012, 2012a.

Peters, G. P., Marland, G., Le Quéré, C., Boden, T. A., Canadell, J. G., and Raupach, M. R.: Correspondence: Rapid growth in $\mathrm{CO}_{2}$ emissions after the 2008-2009 global financial crisis, Nature Climate Change, 2, 2-4, 2012b.

Peters, G. P., Andrew, R. M., Boden, T., Canadell, J. G., Ciais, P., Le Quéré, C., Marland, G., Raupach, M. R., and Wilson, C.: The challenge to keep global warming below $2{ }^{\circ} \mathrm{C}$, Nature Climate Change, 3, 4-6, 2013.

Peters, G. P., Andrew, R. M., Canadell, J. G., Fuss, S., Jackson, R. B., Korsbakken, J. I., Le Quéré, C., and Nakicenovic, N.: Key indicators to track current progress and future ambition of the Paris Agreement, Nature Climate Change, in review, 2016.

Peters, W., Krol, M. C., van der Werf, G. R., Houweling, S., Jones, C. D., Hughes, J., Schaefer, K., Masarie, K. A., Jacobson, A. R., Miller, J. B., Cho, C. H., Ramonet, M., Schmidt, M., Ciattaglia, L., Apadula, F., Heltai, D., Meinhardt, F., Di Sarra, A. G., Piacentino, S., Sferlazzo, D., Aalto, T., Hatakka, J., Ström, J., Haszpra, L., Meijer, H. A. J., Van Der Laan, S., Neubert, R. E. M., Jordan, A., Rodó, X., Morguí, J.-A., Vermeulen, A. T., Popa, E., Rozanski, K., Zimnoch, M., Manning, A. C., Leuenberger, M., Uglietti, C., Dolman, A. J., Ciais, P., Heimann, M., and Tans, P. P.: Seven years of recent European net terrestrial carbon dioxide exchange constrained by atmospheric observations, Glob. Change Biol., 16, 1317-1337, 2010.

Pfeil, B., Olsen, A., Bakker, D. C. E., Hankin, S., Koyuk, H., Kozyr, A., Malczyk, J., Manke, A., Metzl, N., Sabine, C. L., Akl, J., Alin, S. R., Bates, N., Bellerby, R. G. J., Borges, A., Boutin, J., Brown, P. J., Cai, W.-J., Chavez, F. P., Chen, A., Cosca, C., Fassbender, A. J., Feely, R. A., González-Dávila, M., Goyet, C., Hales, B., Hardman-Mountford, N., Heinze, C., Hood, M., Hoppema, M., Hunt, C. W., Hydes, D., Ishii, M., Johannessen, T., Jones, S. D., Key, R. M., Körtzinger, A., Landschützer, P., Lauvset, S. K., Lefèvre, N., Lenton, A., Lourantou, A., Merlivat, L., Midorikawa, T., Mintrop, L., Miyazaki, C., Murata, A., Nakadate, A., Nakano, Y., Nakaoka, S., Nojiri, Y., Omar, A. M., Padin, X. A., Park, G.-H., Paterson, K., Perez, F. F., Pierrot, D., Poisson, A., Ríos, A. F., Santana-Casiano, J. M., Salisbury, J., Sarma, V. V. S. S., Schlitzer, R., Schneider, B., Schuster, U., Sieger, R., Skjel- van, I., Steinhoff, T., Suzuki, T., Takahashi, T., Tedesco, K., Telszewski, M., Thomas, H., Tilbrook, B., Tjiputra, J., Vandemark, D., Veness, T., Wanninkhof, R., Watson, A. J., Weiss, R., Wong, C. S., and Yoshikawa-Inoue, H.: A uniform, quality controlled Surface Ocean $\mathrm{CO}_{2}$ Atlas (SOCAT), Earth Syst. Sci. Data, 5, 125-143, doi:10.5194/essd-5-125-2013, 2013.

Pongratz, J., Reick, C. H., Raddatz, T., and Claussen, M.: Effects of anthropogenic land cover change on the carbon cycle of the last millennium, Global Biogeochem. Cy., 23, GB4001, doi:10.1029/2009GB003488, 2009.

Prather, M. J., Holmes, C. D., and Hsu, J.: Reactive greenhouse gas scenarios: Systematic exploration of uncertainties and the role of atmospheric chemistry, Geophys. Res. Lett., 39, L09803, doi:10.1029/2012GL051440, 2012.

Prentice, I. C., Farquhar, G. D., Fasham, M. J. R., Goulden, M. L., Heimann, M., Jaramillo, V. J., Kheshgi, H. S., Le Quéré, C., Scholes, R. J., and Wallace, D. W. R.: The Carbon Cycle and Atmospheric Carbon Dioxide. In: Climate Change 2001: The Scientific Basis. Contribution of Working Group I to the Third Assessment Report of the Intergovernmental Panel on Climate Change, edited by: Houghton, J. T., Ding, Y., Griggs, D. J., Noguer, M., van der Linden, P. J., Dai, X., Maskell, K., and Johnson, C. A., Cambridge University Press, Cambridge, United Kingdom and New York, NY, USA, 2001.

Randerson, J. T., Chen, Y., van der Werf, G. R., Rogers, B. M., and Morton, D. C.: Global burned area and biomass burning emissions from small fires, J. Geophys. Res.-Biogeo., 117, G04012, doi:10.1029/2012JG002128, 2012.

Raupach, M. R., Marland, G., Ciais, P., Le Quéré, C., Canadell, J. G., Klepper, G., and Field, C. B.: Global and regional drivers of accelerating $\mathrm{CO}_{2}$ emissions, P. Natl. Acad. Sci. USA, 104, 10288-10293, 2007.

Regnier, P., Friedlingstein, P., Ciais, P., Mackenzie, F. T., Gruber, N., Janssens, I. A., Laruelle, G. G., Lauerwald, R., Luyssaert, S., Andersson, A. J., Arndt, S., Arnosti, C., Borges, A. V., Dale, A. W., Gallego-Sala, A., Goddéris, Y., Goossens, N., Hartmann, J., Heinze, C., Ilyina, T., Joos, F., La Rowe, D. E., Leifeld, J., Meysman, F. J. R., Munhoven, G., Raymond, P. A., Spahni, R., Suntharalingam, P., and Thullner M.: Anthropogenic perturbation of the carbon fluxes from land to ocean, Nat. Geosci., 6, 597-607, 2013.

Reick, C. H., T. Raddatz, V. Brovkin, and Gayler, V.: The representation of natural and anthropogenic land cover change in MPIESM, J. Adv. Model. Earth Syst., 5, 459-482, 2013.

Rhein, M., Rintoul, S. R., Aoki, S., Campos, E., Chambers, D., Feely, R. A., Gulev, S., Johnson, G. C., Josey, S. A., Kostianoy, A., Mauritzen, C., Roemmich, D., Talley, L. D., and Wang, F.: Chapter 3: Observations: Ocean. In: Climate Change 2013 The Physical Science Basis, Cambridge University Press, 2013.

Rödenbeck, C.: Estimating $\mathrm{CO}_{2}$ sources and sinks from atmospheric mixing ratio measurements using a global inversion of atmospheric transport, Max Plank Institute, MPI-BGC, 2005.

Rödenbeck, C., Houweling, S., Gloor, M., and Heimann, M.: $\mathrm{CO}_{2}$ flux history 1982-2001 inferred from atmospheric data using a global inversion of atmospheric transport, Atmos. Chem. Phys., 3, 1919-1964, doi:10.5194/acp-3-1919-2003, 2003.

Rödenbeck, C., Keeling, R. F., Bakker, D. C. E., Metzl, N., Olsen, A., Sabine, C., and Heimann, M.: Global surface-ocean $p \mathrm{CO}_{2}$ and sea-air $\mathrm{CO}_{2}$ flux variability from an observation- 
driven ocean mixed-layer scheme, Ocean Sci., 9, 193-216, doi:10.5194/os-9-193-2013, 2013.

Rödenbeck, C., Bakker, D. C. E., Metzl, N., Olsen, A., Sabine, C., Cassar, N., Reum, F., Keeling, R. F., and Heimann, M.: Interannual sea-air $\mathrm{CO}_{2}$ flux variability from an observationdriven ocean mixed-layer scheme, Biogeosciences, 11, 45994613, doi:10.5194/bg-11-4599-2014, 2014.

Rödenbeck, C., Bakker, D. C. E., Gruber, N., Iida, Y., Jacobson, A. R., Jones, S., Landschützer, P., Metzl, N., Nakaoka, S., Olsen, A., Park, G.-H., Peylin, P., Rodgers, K. B., Sasse, T. P., Schuster, U., Shutler, J. D., Valsala, V., Wanninkhof, R., and Zeng, J.: Data-based estimates of the ocean carbon sink variability first results of the Surface Ocean $p \mathrm{CO}_{2}$ Mapping intercomparison (SOCOM), Biogeosciences, 12, 7251-7278, doi:10.5194/bg12-7251-2015, 2015.

Rypdal, K., Paciomik, N., Eggleston, S., Goodwin, J., Irving, W., Penman, J., and Woodfield, M.: Chapter 1 Introduction to the 2006 Guidelines, in: 2006 IPCC Guidelines for National Greenhouse Gas Inventories, edited by: Eggleston, S., Buendia, L., Miwa, K., Ngara, T., and Tanabe, K., Institute for Global Environmental Strategies (IGES), Hayama, Kanagawa, Japan, 2006.

Schimel, D., Alves, D., Enting, I., Heimann, M., Joos, F., Raynaud, D., Wigley, T., Prater, M., Derwent, R., Ehhalt, D., Fraser, P., Sanhueza, E., Zhou, X., Jonas, P., Charlson, R., Rodhe, H., Sadasivan, S., Shine, K. P., Fouquart, Y., Ramaswamy, V., Solomon, S., Srinivasan, J., Albritton, D., Derwent, R., Isaksen, I., Lal, M., and Wuebbles, D.: Radiative Forcing of Climate Change, in: Climate Change 1995 The Science of Climate Change. Contribution of Working Group I to the Second Assessment Report of the Intergovernmental Panel on Climate Change, edited by: Houghton, J. T., Meira Rilho, L. G., Callander, B. A., Harris, N., Kattenberg, A., and Maskell, K., Cambridge University Press, Cambridge, United Kingdom and New York, NY, USA, 1995.

Schwietzke, S., Sherwood, O. A., Bruhwiler, L. M. P., Miller, J. B., Etiope, G., Dlugokencky, E. J., Michel, S. E., Arling, V. A., Vaughn, B. H., White, J. W. C., and Tans, P. P.: Upward revision of global fossil fuel methane emissions based on isotope database, Nature, 538, 88-91, 2016.

Schwinger, J., Goris, N., Tjiputra, J. F., Kriest, I., Bentsen, M., Bethke, I., Ilicak, M., Assmann, K. M., and Heinze, C.: Evaluation of NorESM-OC (versions 1 and 1.2), the ocean carboncycle stand-alone configuration of the Norwegian Earth System Model (NorESM1), Geosci. Model Dev., 9, 2589-2622, doi:10.5194/gmd-9-2589-2016, 2016.

Scripps: The Keeling Curve, available at: http://keelingcurve.ucsd. edu/, last access: 7 November 2013.

Séférian, R., Bopp, L., Gehlen, M., Orr, J., Ethé, C., Cadule, P., Aumont, O., Salas y Mélia, D., Voldoire, A., and Madec, G.: Skill assessment of three earth system models with common marine biogeochemistry, Clim. Dynam., 40, 2549-2573, 2013.

Shevliakova, E., Pacala, S. W., Malyshev, S., Hurtt, G. C., Milly, P. C. D., Caspersen, J. P., Sentman, L. T., Fisk, J. P., Wirth, C., and Crevoisier, C.: Carbon cycling under 300 years of land use change: Importance of the secondary vegetation sink, Global Biogeochem. Cy., 23, GB2022, doi:10.1029/2007GB003176, 2009.

Sitch, S., Smith, B., Prentice, I. C., Arneth, A., Bondeau, A., Cramer, W., Kaplan, J. O., Levis, S., Lucht, W., Sykes, M. T., Thonicke, K., and Venevsky, S.: Evaluation of ecosystem dynam- ics, plant geography and terrestrial carbon cycling in the LPJ dynamic global vegetation model, Glob. Change Biol., 9, 161-185, 2003.

Sitch, S., Friedlingstein, P., Gruber, N., Jones, S. D., MurrayTortarolo, G., Ahlström, A., Doney, S. C., Graven, H., Heinze, C., Huntingford, C., Levis, S., Levy, P. E., Lomas, M., Poulter, B., Viovy, N., Zaehle, S., Zeng, N., Arneth, A., Bonan, G., Bopp, L., Canadell, J. G., Chevallier, F., Ciais, P., Ellis, R., Gloor, M., Peylin, P., Piao, S. L., Le Quéré, C., Smith, B., Zhu, Z., and Myneni, R.: Recent trends and drivers of regional sources and sinks of carbon dioxide, Biogeosciences, 12, 653679, doi:10.5194/bg-12-653-2015, 2015.

Smith, B., Wårlind, D., Arneth, A., Hickler, T., Leadley, P., Siltberg, J., and Zaehle, S.: Implications of incorporating N cycling and $\mathrm{N}$ limitations on primary production in an individualbased dynamic vegetation model, Biogeosciences, 11, 20272054, doi:10.5194/bg-11-2027-2014, 2014.

Stephens, B. B., Gurney, K. R., Tans, P. P., Sweeney, C., Peters, W., Bruhwiler, L., Ciais, P., Ramonet, M., Bousquet, P., Nakazawa, T., Aoki, S., Machida, T., Inoue, G., Vinnichenko, N., Lloyd, J., Jordan, A., Heimann, M., Shibistova, O., Langenfelds, R. L., Steele, L. P., Francey, R. J., and Denning, A. S.: Weak Northern and Strong Tropical Land Carbon Uptake from Vertical Profiles of Atmospheric $\mathrm{CO}_{2}$, Science, 316, 1732-1735, 2007.

Stocker, B. D. and Joos, F.: Quantifying differences in land use emission estimates implied by definition discrepancies, Earth Syst. Dynam., 6, 731-744, doi:10.5194/esd-6-731-2015, 2015.

Stocker, B. D., Feissli, F., Strassmann, K. M., Spahni, R., and Joos, F.: Past and future carbon fluxes from land use change, shifting cultivation and wood harvest, Tellus B, 66, 23188, doi:10.3402/tellusb.v66.23188, 2014.

Stocker, T., Qin, D., and Platner, G.-K.: Climate Change 2013 The Physical Science Basis, Cambridge University Press, 2013.

Sweeney, C., Gloor, E., Jacobson, A. R., Key, R. M., McKinley, G., Sarmiento, J. L., and Wanninkhof, R.: Constraining global air-sea gas exchange for $\mathrm{CO}_{2}$ with recent bomb ${ }^{14} \mathrm{C}$ measurements, Global Biogeochem. Cy., 21, GB2015, doi:10.1029/2006GB002784, 2007.

Tans, P. and Keeling, R. F.: Trends in atmospheric carbon dioxide, National Oceanic \& Atmospheric Administration, Earth System Research Laboratory (NOAA/ESRL) \& Scripps Institution of Oceanography, available at: http://www.esrl.noaa.gov/gmd/ ccgg/trends/ and http://scrippsco2.ucsd.edu/ (last access: $8 \mathrm{Au}$ gust 2014), NOAA/ESRL, 2014.

Tian, H., Liu, M., Z, h. C., Ren, W., Xu, X., Chen, G., Lu, C., and Tao, B.: The Dynamic Land Ecosystem Model (DLEM) for Simulating Terrestrial Processes and Interactions in the Context of Multifactor Global Change, Acta Geographica Sinica, 65, 1027 1047, 2010.

UN: United Nations Statistics Division: Energy Statistics, available at: http://unstats.un.org/unsd/energy/, last access: October 2015a.

UN: United Nations Statistics Division: Industry Statistics, available at: http://unstats.un.org/unsd/industry/default.asp, last access: October $2015 b$.

UN: United Nations Statistics Division: National Accounts Main Aggregates Database, available at: http://unstats.un.org/unsd/ snaama/Introduction.asp (last access: December 2015), 2015c.

USGS: 2014 Minerals Yearbook - Cement, US Geological Survey, Reston, Virginia, 2016a. 
USGS: Mineral Commodities Summaries: Cement, USGS, Reston, Virginia, 2016b.

van der Werf, G. R., Dempewolf, J., Trigg, S. N., Randerson, J. T., Kasibhatla, P., Giglio, L., Murdiyarso, D., Peters, W., Morton, D. C., Collatz, G. J., Dolman, A. J., and DeFries, R. S.: Climate regulation of fire emissions and deforestation in equatorial Asia, P. Natl. Acad. Sci. USA, 15, 20350-20355, 2008.

van der Werf, G. R., Randerson, J. T., Giglio, L., Collatz, G. J., Mu, M., Kasibhatla, P. S., Morton, D. C., DeFries, R. S., Jin, Y., and van Leeuwen, T. T.: Global fire emissions and the contribution of deforestation, savanna, forest, agricultural, and peat fires (19972009), Atmos. Chem. Phys., 10, 11707-11735, doi:10.5194/acp10-11707-2010, 2010.

van Minnen, J. G., Goldewijk, K. K., Stehfest, E., Eickhout, B., van Drecht, G., and Leemans, R.: The importance of three centuries of land-use change for the global and regional terrestrial carbon cycle, Climatic Change, 97, 123-144, 2009.

Viovy, N.: CRUNCEP data set, available at: ftp://nacp.ornl.gov/ synthesis/2009/frescati/temp/land_use_change/original/readme. htm (last access: June 2016), 2016.

Wanninkhof, R., Park, G.-H., Takahashi, T., Sweeney, C., Feely, R., Nojiri, Y., Gruber, N., Doney, S. C., McKinley, G. A., Lenton, A., Le Quéré, C., Heinze, C., Schwinger, J., Graven, H., and Khatiwala, S.: Global ocean carbon uptake: magnitude, variability and trends, Biogeosciences, 10, 1983-2000, doi:10.5194/bg10-1983-2013, 2013.

Watson, R. T., Rodhe, H., Oeschger, H., and Siegenthaler, U.: Greenhouse Gases and Aerosols, in: Climate Change: The IPCC Scientific Assessment. Intergovernmental Panel on Climate Change (IPCC), edited by: Houghton, J. T., Jenkins, G. J., and Ephraums, J. J., Cambridge University Press, Cambridge, 1990.
Woodward, F. I. and Lomas, M. R.: Vegetation dynamics - simulating responses to climatic change, Biol. Rev., 79, 643-670, doi:10.1017/S1464793103006419, 2004.

Woodward, F. I., Smith, T. M., and Emanuel, W. R.: A global land primary productivity and phytogeography model, Global Biogeochem. Cy., 9, 471-490, 1995.

Yin, Y., Ciais, P., Chevallier, F., van der Werf, G. R., Fanin, T., Broquet, G., Boesch, H., Cozic, A., Hauglustaine, D., Szopa, S., and Wang, Y.: Variability of fire carbon emissions in Equatorial Asia and its non-linear sensitivity to El Niño, Geophys. Res. Lett., 43, 10472-10479, 2016.

Zaehle, S. and Friend, A. D.: Carbon and nitrogen cycle dynamics in the O-CN land surface model: 1. Model description, site-scale evaluation, and sensitivity to parameter estimates, Global Biogeochem. Cy., 24, GB1005, doi:10.1029/2009GB003521, 2010.

Zaehle, S., Ciais, P., Friend, A. D., and Prieur, V.: Carbon benefits of anthropogenic reactive nitrogen offset by nitrous oxide emissions, Nat. Geosci., 4, 601-605, 2011.

Zhang, H. Q., Pak, B., Wang, Y. P., Zhou, X. Y., Zhang, Y. Q., and Zhang, L.: Evaluating Surface Water Cycle Simulated by the Australian Community Land Surface Model (CABLE) across Different Spatial and Temporal Domains, J. of Hydrometeorol., 14, 1119-1138, 2013. 